\title{
IMPACTOS DAS VARIÁVEIS MACROECONÔMICAS SOBRE O DESEMPENHO DAS COOPERATIVAS DE CAFÉ DO ESTADO DE MINAS GERAIS
}

\section{CLAUDIA GONÇALVES SILVA FRANCO}

Bacharel em Ciências Econômicas

Orientador: Prof. Dr. SIGISMUNDO BIALOSKORSKI NETO

Dissertação apresentada à Escola Superior de Agricultura "Luiz de Queiroz" da Universidade de São Paulo, para obtenção do Título de Mestre em Ciências, Área de Concentração: Economia Aplicada.

PIR A C I C A B A

Estado de São Paulo - Brasil

Novembro - 2002 


\section{ERRATA}

\section{Autora: Claudia Gonçalves Silva Franco}

Titulo da Dissertação: Impactos das Variáveis Macroeconômicas sobre o Desempenho das Cooperativas de Café do Estado de Minas Gerais

\begin{tabular}{|c|c|c|c|c|}
\hline p. & İtem & linha & Onde se lê & Leia-se \\
\hline xiv & Summary & vigésima segunda & $\ldots$ (sobras) $\ldots . .$. & ...(financial results) \\
\hline 08 & 2.1.1.1 & décima segunda & Segundo Resende Lopes (1993).. & Segundo Lopes (1993)... \\
\hline 10 & 2.1.1.1 & décima nona & Para Resende Lopes (1993), o periodo... & Para Lopes (1993), o periodo... \\
\hline 16 & 2.1 .3 & vigésima sexta & ... de garantias adicionais. & ... de garantias adicionais (Bianco, 2000). \\
\hline 19 & 2.1.3.1 & décima oitava & ...acedente... & ...ascendente... \\
\hline 22 & 2.2 & vigésima sexta & ...os diferencias.... & ...os diferenciais... \\
\hline 29 & 3.1 & vigésima segunda & $\begin{array}{l}\text { Empregava diretamente, em 1988, quatro } \\
\text { milhōes...serviços (Caixeta, 1989)... }\end{array}$ & $\begin{array}{l}\text { Empregava diretamente, em 1998, em torno de quatro } \\
\text { milhðes...serviços (Caixeta, 1999)... }\end{array}$ \\
\hline 32 & 3.2 & segunda & ...Café (IBC) (Caixeta, 1989). & ...Café (IBC) \\
\hline 38 & 4.1 & vigésima primeira & ..eliminação da inflação.... & ....queda da inflação.... \\
\hline 38 & 4.1 .1 & vigésima terceira & ...em torno de 150 municípios mineiros.... & ...em torno de 250 municípios no sul de Minas... \\
\hline 40 & 4.1.1 & décima terceira & ....também o café como atividade... & ...também têm o café como atividade..... \\
\hline 40 & 4.1.1 & décima sexta & ...cooperativa alcança municípios mineiros... & ...cooperativa alcança 06 municipios mineiros... \\
\hline 50 & 4.2 .1 .3 & sétima & $\begin{array}{l}\mathrm{PC}=\text { Passivo Circulante (defina se esses indices terão } \\
\text { inicial maiúscula ou minúscula) }\end{array}$ & $\mathrm{PC}=$ passivo circulante \\
\hline 53 & 4.2 .1 .4 & sexta $\quad$ & ...foi superior ao.... & ... foi menor em relação ao... \\
\hline 53 & 4.2 .1 .4 & vigésima primeira & ...indices superiores... & $\ldots$ indices menores.... \\
\hline 54 & 4.2 .1 .4 & terceira : & ...(apêndice 1 e 2), neste ano, a taxa de câmbio... & $\begin{array}{l}\text {...(apêndice } 1 \text { e 2) neste ano e, também a taxa de } \\
\text { câmbio... }\end{array}$ \\
\hline 54 & 4.2.1.4 & sexta & Figura 4 - ... Próprios média das cooperativas... & Figura 4 - ... Próprios médio das cooperativas... \\
\hline 55 & 4.2.1.5 & sétima & Tabela $6 . .$. financeira (IF) em $\%$ das cooperativas.... & $\begin{array}{l}\text { Tirar das tabelas } 6,8,9,10 \text { e } 11 \text { o "em \%" e colocar no } \\
\text { final, após Minas Gerais somente "(\%)" }\end{array}$ \\
\hline 57 & 4.2 .1 .6 & décima oitava & ... análise foi inferior ao valor da década... & $\ldots$ análise foi inferior $(1,19)$ ao valor da década... \\
\hline 58 & 4.2 .1 .6 & décima nona & $\ldots$ do câmbio verificada nos de ... & ... do câmbio verificada nos anos de ... \\
\hline 61 & 4.2 .1 .7 & décima & ...Terem apresentado sobras negativas... & ...terem apresentado perdas... \\
\hline 62 & 4.2.1.8 & vigésima terceira & Aiternativas. ao interpretaçăo do índice RPL é no & Alternativas. A interpretação do índice RPL é no .... \\
\hline 63 & 4.2 .1 .8 & décima terceira & ...indicando prejuizos ocorridos... & $\ldots$ indicando perdas ocorridas... \\
\hline 63 & 4.2 .1 .8 & décima quarta & $\ldots$ melhora desse indice $(0,24) \ldots$ & ... melhora desse indice $(24 \%) \ldots$ \\
\hline 63 & 4.2 .1 .8 & décima sexta & .... muita baixa em relaçăo... & ... relativamente alta em relação... \\
\hline 63 & 4.2 .1 .8 & décima sétima & Paraná $\quad$ : : & Paraná (1,23 \% - índice-padrão). \\
\hline 67 & 4.2 .1 .9 & décima & ...do ELP são a instabilidade... & ...do ELP foi a instabilidade... \\
\hline 73 & 5.1 & segunda & ...conhecer variáveis macro que influenciam... & $\begin{array}{l}\text {...conhecer variáveis macroeconômicas que } \\
\text { influenciam... }\end{array}$ \\
\hline 77 & 5.2 & terceira & $\ldots$ de 1980 a 2000 , e de $1990 \ldots$ & $\ldots$ de 1980 a 2000 e de $1990 \ldots$ \\
\hline 77 & 5.2 & quinta & ... que e dada... & ... que é dada... \\
\hline 78 & 5.2 & sétima & $\begin{array}{l}\mathrm{CCMG}=\text { valor dos contratos do crédito para o café } \\
\text { em Minas Gerais; }\end{array}$ & $\begin{array}{l}\mathrm{CCMG}=\text { valor dos contratos de crédito para custeio } \\
\text { do café em Minas Gerais; }\end{array}$ \\
\hline 78 & 5.2 & oitava & $\begin{array}{l}\text {..PRSCUS = preço pago ao produtor da saca de café } \\
(60 \mathrm{~kg} \text { beneficiada em US\$) } \ldots\end{array}$ & $\begin{array}{l}\text {..PRSCUS = preço médio da saca de ca fé beneficiado } \\
\text { (60 kg em US\$) pago ao produtor pela cooperativa... }\end{array}$ \\
\hline 78 & 5.2 & nona & $\ldots E L P=$ endividamento... & $\ldots E L P=$ indice de endividamento $\ldots$ \\
\hline 78 & 5.2 & nona & ...LC $=$ liquidez corrente & $\ldots L C=$ indice de liquidez corrente \\
\hline 79 & 5.2 & décima sétima & ... beneficiado $(60 \mathrm{~kg})$ pago.... & ... beneficiado (60 $\mathrm{kg} \mathrm{em}$ USS) pago.... \\
\hline 81 & 5.2 .1 & décima quarta & Menegário (2001), ao avaliar... & Menegário \& Araújo (2001), ao avaliar... \\
\hline 82 & 5.2 .1 & décima sexta & $\begin{array}{l}\text { Logato (1994), em seus estudos sobre a } \\
\text { cafeicultura....., confirma os resultados encontrados } \\
\text { rieste trabalho.... }\end{array}$ & $\begin{array}{l}\text { Este trabalho confirma os resultados encontrados por } \\
\text { Logato (1994), em ...1990, no que diz respeito.... }\end{array}$ \\
\hline 88 & 6 & oitava & ...Rentabilidade do Patrimônio Liquido,... & $\begin{array}{l}\text {...Rentabilidade do Patrimônio Líquido, Imobilização } \\
\text { dos Recursos Próprios.... }\end{array}$ \\
\hline 88 & 6 & décima sétima & $\begin{array}{l}\text {...e Imobilizaçăo dos Recursos Próprios apresentaram } \\
\text { os melhores... }\end{array}$ & ...apresentaram os melhores .... \\
\hline 91 & $\begin{array}{l}\text { Referências } \\
\text { bibliográficas }\end{array}$ & & & $\begin{array}{l}\text { Incluir na referência bibliográfica : BIANCO, J. } \\
\text { Estrutura e desempenho das cooperativas } \\
\text { agropecuárias de café do estado de São Paulo. } \\
\text { Faculdade de Engenharia Agrícola, } \\
\text { FEAGRI/UNICAMP. (Tese de doutorado). Campinas, } \\
2000.179 \text { p. }\end{array}$ \\
\hline 92 & $\begin{array}{l}\text { Referências } \\
\text { bibliográficas }\end{array}$ & Sexta & CAIXETA, G.Z.T. Tendências... & $\begin{array}{l}\text { CAIXETA, G.Z.T. A Globalização e o mercado de } \\
\text { café. Informe Agropecuário, Belo Horizonte, v. } 20 \text {, n. } \\
199 \text {, jul/ago. 1999. p. } 74-82\end{array}$ \\
\hline
\end{tabular}




\section{Dados Internacionais de Catalogação na Publicação (CIP) DIVISĀO DE BIBLIOTECA E DOCUMENTAÇÃO - ESALQ/USP}

\section{Franco, Claudia Gonçalves Silva}

Impactos das variáveis macroeconômicas sobre o desempenho das cooperativas de café do Estado de Minas Gerais / Claudia Gonçalves Silva Franco. - - Piracicaba, 2002.

$104 \mathrm{p}$.

Dissertação (mestrado) - - Escola Superior de Agricultura Luiz de Queiroz, 2002. Bibliografia.

1. Café 2. Cooperativa agricola 3. Indicadores econômicos 4. Macroeconomia 5. Minas Gerais I. Título

CDD 338.17373 


\section{Ofereço}

A meus pais, meus irmãos $e$,

em especial, a Graça minha irmã e a minha família

em Cristo. Sem vocês esse trabalho não seria possível

Dedico

Ao meu filho João Samuel e ao meu esposo, João Marcos, pelo incentivo, paciência e compreensão, os quais espero poder retribuir até quando o nosso Deus permitir. 


\section{AGRADECIMENTOS}

Sou grata, em primeiro lugar, ao SENHOR DEUS, autor da vida, da esperança daqueles que NELE esperam, fonte de toda a vida, e de toda a SABEDORIA;

De modo especial ao meu esposo, João Marcos, pela orientação, apoio, incentivo e condições que propiciou para o sucesso dessa pesquisa;

Ao meu orientador, Prof. Dr. Sigismundo Bialoskorski Neto, da FEA/USP Ribeirão Preto (SP), pela paciência e significativas contribuições que nortearam meus esforços para um fim proveitoso;

Ao Prof. Dr. Marcelo José Braga do Departamento de Economia Rural da Universidade Federal de Viçosa - UFV, pela enorme contribuição e sugestões apresentadas;

Aos professores componentes da Banca: Prof. Dr. Pedro Valentim Marques, Prof. Dr. Alexandre Lahóz Mendonça de Barros e Prof. Dr. Marcelo José Braga, pelas valiosas sugestões;

Aos professores e a todos os funcionários do Departamento de Economia, Administração e Sociologia da ESALQ, mas, em especial, a Maielli, Ligiana e Helena e a Ana Paula do CEPEA, pela maneira cordial e eficiente, através das quais atenderam às minhas demandas. 
Aos dirigentes e funcionários do setor de contabilidade das cooperativas de cafeicultores de Minas Gerais (COOXUPÉ, COOPARAÍSO, CAFEPOÇOS, MINASUL, CARPEC, COOCAFÉ, COAVAP), cuja colaboração foi fundamental para o desenvolvimento e a realização deste trabalho;

A todos aqueles que direta ou indiretamente colaboraram com a realização desta dissertação 


\section{SUMÁRIO}

Página

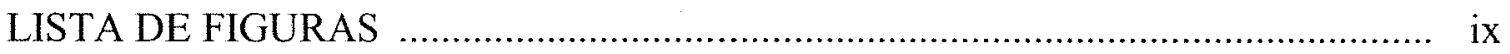

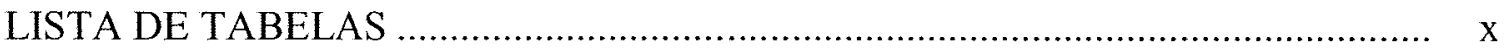

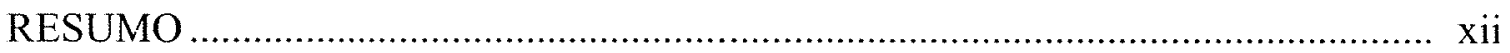

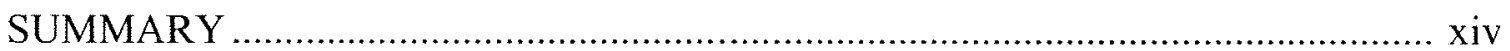

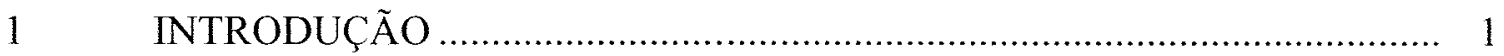

1.1 Importância do problema ..................................................................... 1

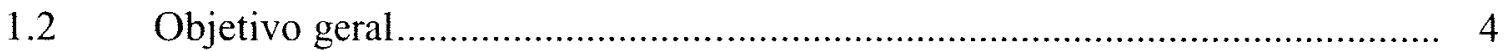

2 ANÁLISE DAS POLÍTICAS ECONÔMICAS E AGRÍCOLAS

DURANTE AS DÉCADAS DE 1980 E 1990 ............................................ 5

$2.1 \quad$ Política econômica ................................................................................ 5

2.1.1 Os anos 80 e os tempos da superinflação....................................................... 6

2.1.1.1 As políticas econômicas e agrícolas durante a década de 80 ……………....... 7

2.1.2 A agricultura brasileira nos anos 90: o impacto das reformas de

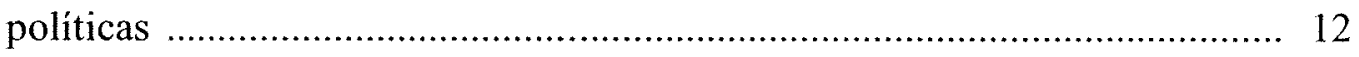

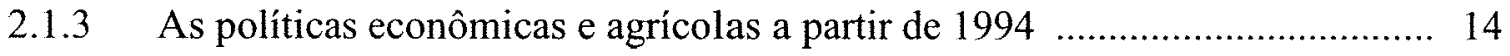

2.1.3.1 A primeira fase do Plano Real ................................................................ 18

2.2 As políticas agrícolas e o cooperativismo ................................................ 20

2.2.1 A criação do Programa de Revitalização das Cooperativas Agropecuárias Brasileiras - RECOOP 
3 CARACTERÍSTICAS DO SETOR CAFEEIRO E POLÍTICAS

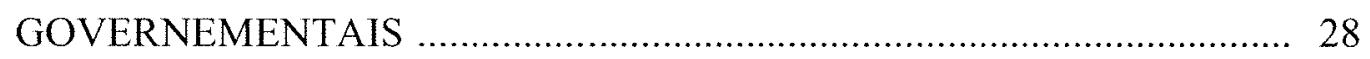

3.1 O Sistema Agro-industrial (SAG) do Café ................................................. 28

3.2 Política econômicas na cafeicultura brasileira .............................................. 29

4 DESEMPENHO ECONÔMICO FINANCEIRO DAS

COOPERATIVAS DE CAFÉ DO ESTADO DE MINAS

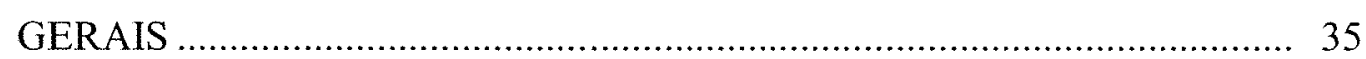

4.1 Área de estudo e fonte de dados......................................................... 37

4.1.1 Caracterização das cooperativas agropecuárias do Estado de

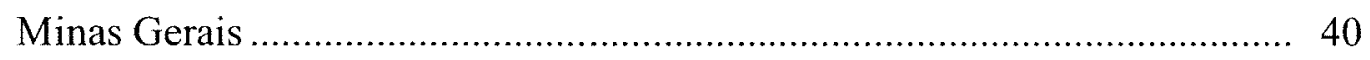

4.2 Indicadores econômicos-financeiros ...................................................... 42

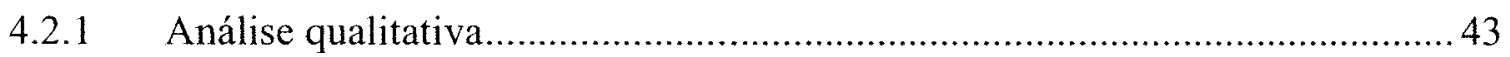

4.2.1.1 Liquidez Corrente (LC) ................................................................... 43

4.2.1.2 Liquidez Seca (LS) ..................................................................... 46

4.2.1.3 Margem de Garantia (MG) ............................................................... 50

4.2.1.4 Imobilização de Recursos Próprios (IRP) ………………….................... 52

4.2.1.5 Independência Financeira (IF) ............................................................. 55

4.2.1.6 Giro do Ativo (GA) ...................................................................... 57

4.2.1.7 Retorno sobre Investimento (RI) ........................................................ 59

4.2.1.8 Rentabilidade do Patrimônio Liquido (RPL) ………….......................... 62

4.2.1.9 Endividamento de Longo Prazo (ELP) ………................................... 65

4.2.1.10 Endividamento Total (ET) ....................................................................6 68

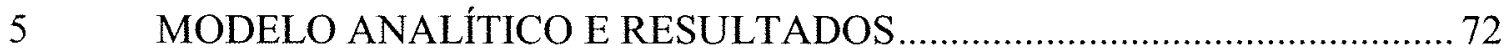

5.1 Descrição das variáveis ............................................................................ 73

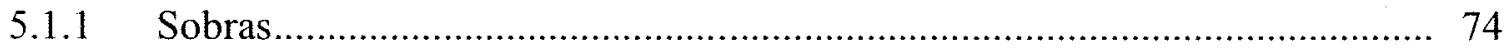

5.1.2 Valor dos Contratos do Crédito para Custeio do Café em Minas

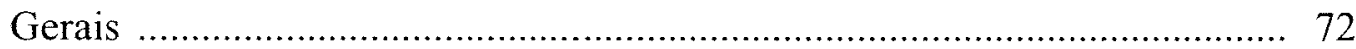

5.1.3 Taxa de Câmbio ................................................................................ 75

5.1.4 Preço da Saca de Café .............................................................................. 76 


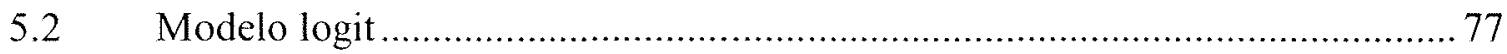

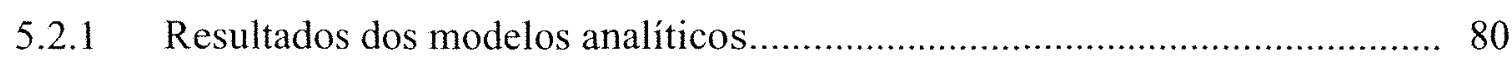

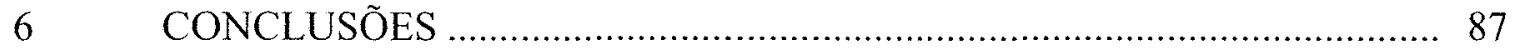

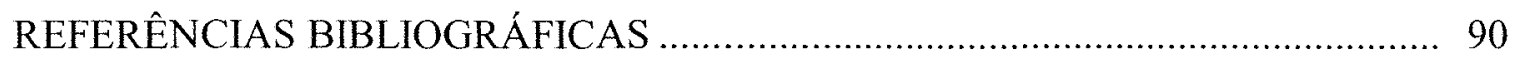

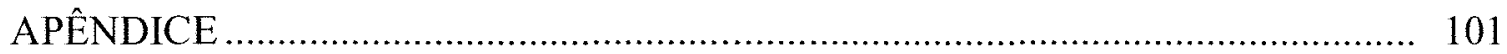




\section{LISTA DE TABELAS}

Página

1 Número de cooperativas, cooperados, funcionários, patrimônio líquido e receitas por ramo, em Minas Gerais 38

2 Índices médios da Liquidez Corrente (LC) das cooperativas de café de Minas Gerais

3 Índices médios da Liquidez Seca (LS) das cooperativas de café de Minas Gerais

4 Índices médios da Margem de Garantia (MG) das cooperativas de café de Minas Gerais

5 Índices médios da Imobilização dos Recursos Próprios (IRP) das cooperativas de café de Minas Gerais

6 Índices médios da Independência Financeira em \% (IF) das cooperativas de café de Minas Gerais

7 Índices médios do Giro do Ativo (GA) das cooperativas de café de Minas Gerais

8 Índices médios do Retorno sob Investimento em \% (RI) das cooperativas de café de Minas Gerais

9 Índices médios da Rentabilidade do Patrimônio Líquido (RPL) das cooperativas de café de Minas Gerais

10 Índices médios do Endividamento de Longo Prazo em \% (ELP) das cooperativas de café de Minas Gerais

11 Índices médios do Endividamento Total em \% (ET) das cooperativas de café de Minas Gerais 


\section{LISTA DE FIGURAS}

Página

1 Liquidez Corrente média das cooperativas de café do estado de Minas Gerais no período de 1980 a 2000 46

2 Liquidez Seca média das cooperativas de café do estado de Minas Gerais no período de 1980 a 2000 49

3 Margem de Garantia média das cooperativas de café do estado de Minas Gerais no período de 1980 a 2000

4 Imobilização dos Recursos Próprios médio das cooperativas de café do estado de Minas Gerais no período de 1980 a 2000.

5 Independência Financeira média das cooperativas de café do estado de Minas Gerais no período de 1980 a 2000

6 Giro médio do Ativo das cooperativas de café do estado de Minas Gerais no período de 1980 a 2000

7 Retorno sob Investimento médio das cooperativas de café do estado de Minas Gerais no período de 1980 a 2000

8 Rentabilidade do Patrimônio Liquido médio das cooperativas de café do estado de Minas Gerais no período de 1980 a 2000.

9 Endividamento de Longo Prazo médio das cooperativas de café do estado de Minas Gerais no período de 1980 a 2000.

10 Endividamento Total médio das cooperativas de café do estado de Minas Gerais no período de 1980 a 2000 
12 Valor dos contratos do crédito rural para o café no estado de Minas Gerais de 1980 a 2000, valores em reais de dezembro/2000

13 Modelo 01: coeficientes estimados do modelo logit para a ocorrência de sobras nas cooperativas de café em Minas Gerais (1980 a 2000)

14 Modelo 02 : coeficientes estimados do modelo logit para a ocorrência de sobras nas cooperativas de café em Minas Gerais (1990-2000). 


\title{
IMPACTOS DAS VARIÁVEIS MACROECONÔMICAS SOBRE O DESEMPENHO DAS COOPERATIVAS DE CAFÉ DO ESTADO DE MINAS GERAIS
}

\author{
Autor: CLAUDIA GONÇALVES SILVA FRANCO \\ Orientador: Prof. Dr. SIGISMUNDO BIALOSKORSKI NETO
}

\section{RESUMO}

As cooperativas, assim como as demais empresas do país atuam em um contexto econômico-financeiro submetido a transformações rápidas e profundas. De um ambiente marcado pela alta inflação, diversos planos de estabilização econômica, com alto grau de intervenção e economia fechada, caminhou-se para uma economia inserida no contexto global e com relativa estabilidade macroeconômica. Estas transformações promoveram considerável impacto sobre a agricultura, e agravam-se mediante o alto grau de protecionismo dos países desenvolvidos aos seus produtores. As políticas econômicas, de modo geral, e aquelas direcionadas ao setor agrícola impactaram, de forma diferenciada, os diversos setores da economia. O presente trabalho teve como objetivo geral analisar o impacto das variáveis macroeconômicas sobre o desempenho das cooperativas de café do estado de Minas Gerais, durante o período de 1980 a 2000. E, especificamente, analisar o comportamento dos indicadores financeiros dessas cooperativas, ao longo da série de anos estudados. Para o alcance dos objetivos propostos foram utilizados como métodos dois instrumentos, modelo analítico (Logit) em que a variável dependente admite valores discretos, zero e um - variável binária; e apresentação gráfica do comportamento dos indicadores financeiros ao longo dos anos 
estudados. Os resultados do modelo ajustado identificou quatro variáveis estatisticamente significativas, quais sejam, valor dos Contratos do Crédito para custeio em Minas Gerais, (CCMG), Taxa de Câmbio (TXCAM), Preço pago ao produtor da saca de café em dólar (PRSCUS), e Liquidez Corrente (LIQCOR). O volume de crédito para o custeio do café em Minas Gerais influenciou positivamente a ocorrência das sobras, mostrando a importância da política de crédito com disponibilidade de recursos. A variável Taxa de Câmbio (TXCAM), também mostrou-se importante e com efeito positivo na ocorrência de sobras nas cooperativas. Isto significa que desvalorizações do câmbio favoreceram o desempenho financeiro dessas cooperativas exportadoras de café. O Preço pago ao produtor da saca de café em dólar (PRSCUS), apresentou impacto negativo da ocorrência de sobras nas cooperativas. Quando a PRSCUS estava crescendo, ou seja, quando a cooperativa pagou mais pela saca de café ao associado, as sobras decresceram. Assim, concluí-se pela importância da consideração destas variáveis macroeconômicas para a análise do desempenho de cooperativas. 


\title{
IMPACT OF MACROECONOMICS VARIABLES APPLIED TO THE AGRICULTURE ON THE DEVELOPMENT OF COFFEE COOPERATIVE FIRMS IN MINAS GERAIS
}

\author{
Author: CLAUDIA GONÇALVES SILVA FRANCO \\ Adviser: Prof. Dr. SIGISMUNDO BIALOSKORSKI NETO
}

\section{SUMMARY}

The cooperative, as well as other son cooperative companies in Brazil are situated in a financial-economic context which is submitted to fast and deep changes. From an environment marked by high inflation, several plans of economic stabilization, high level of intervening, and closed economy, we moved forward to an economy inserted in a global context which has a relative macroeconomic stability. These changes promoted a considerable impact on the agriculture and these impacts became worse taking into account the high level of protectionism of developed countries to their producers. Economic policies, in a general way, and those ones directed to the agricultural area impacted, in a different way, the several areas of economy. The present ensay had as a general objective to analyze the impact of macroeconomics variables applied to the agriculture on the development of coffee cooperative firms in Minas Gerais from the period of 1980 to 2000 . It was also specifically aimed to analyze the behavior of financial indicators during the period of study about Cooperatives of Coffee Producers for reaching the objectives proposed, two instruments were used as 
methods, analytical model ( Logit) in which the dependent variable admits discreet values, zero and one - binary variable; graphic presentation of behavior of financial indicators during the period of study of coffee cooperative in Minas Gerais. The results of the adjusted model identified four variables statistically significant, whatever they are, value of the credit agreements for costing in Minas Gerais, (CCMG), Exchange Rate (TXCAM), Price paid to the producer for a coffee bag in dollar (PRSCUS), and Current Liquidity (LC). The volume of credit for the costing of coffee influenced positively the occurrence of remaining coffee (sobras), showing the importance of the credit policy with resources availability. The Exchange Rate (TXCAM), also came out to be important and had a positive effect on the occurrence of in the cooperative. That means that devaluation of the exchange rate favor the financial performance of these cooperative firms which are coffee exporters. The price paid to the producer for a coffee in dollar (PRSCUS), presented a negative impact on the occurrence in the cooperative firms. When the PRSCUS was increasing, it is, when the cooperative firm paid more for the coffee to the associate, the decreased. It is possible to conclude the importance of these variables to analyze the cooperatives efficiency. 


\section{INTRODUÇÃO}

\subsection{Importância do problema}

A economia brasileira na década de 1990 iniciou um processo de reestruturação. O comércio exterior tornou-se mais liberalizado, empresas estatais foram privatizadas, os mercados internos desregulamentados, e um Mercado Comum do Cone Sul (MERCOSUL) foi formado. O setor agrícola também sofreu impacto da redefinição econômica do papel do Estado. De um regime de política agrícola concebido para uma economia fechada com forte intervenção estatal, muda-se para um regime de economia aberta e com menor participação do Estado. As cooperativas não ficaram isoladas nesse processo.

Ademais, a crise fiscal do Estado brasileiro afetou negativamente a agricultura e, em conseqüência, o cooperativismo rural. A título de exemplo, a dívida das cooperativas agropecuárias brasileiras junto ao seu principal credor do sistema financeiro (Banco do Brasil), em 1997, ultrapassava a casa dos 3 bilhões de reais. Cerca de $50 \%$ desse total encontrava-se, à época, em situação de inadimplência (Menegário, 2000).

Brandão \& Alves (1993) mostraram a tendência de queda da participação da agricultura na renda, no emprego e nas exportações do país. Segundo esses autores, a participação da agricultura no total das exportações brasileiras caiu de $94 \%$, no período de 1950-59, para 41\%, entre os anos de 1980 e 1987.

Neste estágio, a agricultura e, consequentemente, as cooperativas, eram beneficiárias dos mecanismos de proteção de preço, dos programas de transferência de 
tecnologia e do crédito rural. Em 2000, a participação da agricultura na renda nacional estava em torno de $7 \%$, a indústria participava com $31 \%$ e o setor de serviços, com $52 \%$ (Gasques \& Conceição, 2001). Outro fato importante a ser salientado é quanto aos gastos públicos para a agricultura, que se reduziram sensivelmente de $5,75 \%$, no início da década de 80, para 2,11\%, entre 1995 e 1999 (Gasques, 2001).

As cooperativas, embora apresentem características diferentes de empresas de capital, estão inseridas num ambiente onde as regras políticas, sociais e legais que estabelecem as bases para a produção, a troca e a distribuição são aproximadamente as mesmas. $\mathrm{O}$ ato cooperativo é reconhecido como algo diferente do ato comercial e, portanto, the é garantida uma situação tributária também distinta. Assim, a cooperativa é beneficiada pela isenção de tributos como o Imposto sobre a Renda - pelo fato de essa organização não possuir objetivo de lucro, mas deter apenas sobras do exercício.

Contudo, como as cooperativas têm limitações para capitalização, generalizou-se o problema de falta de liquidez no cooperativismo. Sendo, porém, uma atividade de características peculiares, as cooperativas compõem o único setor da economia que tem ênfase no equilíbrio entre o econômico e o social. Ai reside o seu primeiro problema frente à globalização, que lhes exigiria eficiência e competitividade (Rodrigues, 1997).

Atualmente, o cooperativismo no Brasil encontra-se num vácuo jurídico devido à ausência de uma legislação que venha aperfeiçoar a antiga Lei 5.764/71, ${ }^{1}$ incluídas nesta as modificações efetuadas por ocasião do processo constituinte de 1988 , e ainda não regulamentadas, como a autogestão, o reconhecimento do ato cooperativo como ato diferente do comercial, e o necessário apoio do Estado para o movimento

\footnotetext{
${ }^{1}$ A lei número 5.764, de 16 de dezembro de 1971, expõe em seus artigos $3^{\circ}$ e $4^{\circ}$ os princípios doutrinários da I.C.A. (International Cooperative Alliance), definindo a sociedade cooperativa como uma atividade econômica de proveito comum sem o objetivo de lucro, tendo como características: a adesão voluntária, a variabilidade do capital social representado pelas cotas-partes, singularidade de voto, retorno das sobras líquidas do exercício e neutralidade política e religiosa, entre outras; o artigo $5^{\circ}$, por sua vez, assegura o direito do uso da nomeação "cooperativa"; e o artigo $38^{\circ}$ enfatiza o principio democrático, apontando a assembléia geral com órgão máximo de decisão da cooperativa.
} 
cooperativista. Como conseqüência direta o cooperativismo se encontra em situação que acaba por gerar alguns problemas específicos, como, por exemplo, o fato de não haver uma padronização de controle sobre o registro de uma cooperativa nas juntas comerciais dos estados da Federação (Bialoskorski Neto, 2000).

Há, atualmente, uma situação de transição, em que o cooperativismo encontra a existência de condicionantes institucionais que dificultam o seu processo de crescimento. Como exemplo, cita-se a situação institucional na qual a empresa cooperativa não está sujeita à falência e tampouco tem direito à concordata, o que aumenta o custo financeiro. É negada, também, a possibilidade de emissão de títulos e de abertura de capital por meio de ações.

Doutrinariamente, a cooperativa é um empreendimento em que cada homem associado tem apenas um único voto nas assembléias gerais, não permitindo, portanto, uma divisão diferente dos direitos de propriedade. Dessa forma, o ambiente institucional dado pela Legislação e pela estrutura doutrinária acaba condicionando os custos de transação e, por último, a eficiência desse tipo de organização.

Apesar das peculiaridades das cooperativas que as levam a dificuldades adicionais comparadas às empresas chamadas de capital, o setor cooperativista representava cerca de 6\% do PIB brasileiro em 1999. Nesse mesmo ano, as cooperativas agropecuárias representavam mais de $46 \%$ do total cooperativista do país, gerando em torno de 112.835 empregos diretos, vinculando mais 5.182 .300 pessoas, mas ainda apresentavam um alto grau de endividamento. Grande parte da produção agrícola do país que é exportada origina-se do sistema cooperativista. Como exemplos, observa-se que $29,4 \%$ da soja e $27,9 \%$ do café são comercializados por cooperativas agropecuárias, colaborando para uma balança comercial mais favorável (OCB, 2000).

Quanto à comercialização do café, as vendas externas desse produto realizadas pelas cooperativas em 1998, que se concentravam exclusivamente no café de grãos, ficaram em US\$143,6 milhões, portanto, 10,9\% abaixo do valor total exportado em 1997. No mesmo período, em 1997, o conjunto das exportações brasileiras de café 
caiu $15,1 \%$ em valor monetário. Considerando-se que os preços internacionais do grão tiveram queda de 25,9\% de 1997 para 1998, o volume das exportações feitas pelas cooperativas foi cerca de $13,5 \%$ maior que na temporada anterior (OCB, 1999). Dada a importância das cooperativas na agricultura e da cultura do café na geração de renda, tanto para o estado de Minas Gerais quanto para o país, a pesquisa enfoca o desempenho econômico financeiro das cooperativas de café do estado de Minas Gerais no período de 1980 a 2000.

\section{2 Objetivo geral}

O objetivo geral deste trabalho é analisar o impacto de variáveis macroeconômicas no desempenho econômico e financeiro das cooperativas de café do estado de Minas Gerais.

Especificamente, pretende-se:

- analisar o desempenho das maiores cooperativas de café do estado de Minas Gerais por meio de indicadores financeiros ao longo da série de dados de 1980 a 2000.

Para tanto, a presente pesquisa está estruturada em cinco capítulos além desta introdução. No capítulo 2 faz-se uma breve análise das políticas econômicas e agrícolas durante as décadas de 80 e 90 . No capítulo 3 descreve-se as características do setor cafeeiro e as políticas governamentais. No capítulo 4 têm-se o método de coleta de dados e seu processamento, as considerações teóricas sobre os indicadores de desempenho econômico financeiro das cooperativas, bem como uma análise e discussão do desempenho econômico financeiro das cooperativas de café de Minas Gerais. No capítulo 5, apresentou-se o modelo analítico utilizado para verificar o impacto de variáveis na probabilidade de ocorrência de sobras nas cooperativas. E, por fim, no capítulo 6 são apresentadas as conclusões da pesquisa. 


\section{ANÁlISE DAS POLÍTICAS ECONÔMICAS E AGRÍCOLAS DURANTE AS DÉCADAS DE 1980 E 1990}

\subsection{Política econômica}

A relação de variáveis macroeconômicas com a agricultura pode ser compreendida a partir de uma visão e comparação das políticas dos anos 80 e 90 . A diferença básica dessas décadas foi o deslocamento do perfil do mercado nacional: de fechado, protegido e subsidiado, para aberto, competitivo e menos subsidiado.

Para Schuh (1975), os efeitos de políticas gerais de desenvolvimento econômico dirigidas a outros setores da economia exercem uma influência muito importante também na evolução agrícola do país. Segundo o autor, os economistas agrícolas "pecam" ao ignorar o conjunto global das políticas em seus trabalhos analíticos de pesquisa. Esse autor mostrou que as políticas de desenvolvimento como industrialização forçada, dirigida à substituição de importação, tarifas protecionistas muito altas, superavaliação da taxa de câmbio no estabelecimento de taxas múltiplas e políticas creditícias e fiscais para estimular a indústria, seguidas por muitos países no período pós-guerra, acarretaram sérias conseqüências sobre o setor agrícola, restringindo sua contribuição potencial ao desenvolvimento.

Os efeitos das políticas econômicas sobre os sistemas agro-industriais têm sido o foco das atenções de estudiosos dos problemas relacionados com desenvolvimento econômico durante décadas. Esse interesse se tornou maior a partir dos anos 80, devido ao aumento das distorções causadas pelas intervenções dos 
países da $\mathrm{OCDE}^{2}$ nos seus respectivos sistemas agroindustriais. Essa ação, por sua vez, teve reflexos que extrapolaram os limites geográficos desses países: afetou a competitividade internacional e provocou a queda dos preços agroindustriais no mercado internacional (Campos, 2000).

As políticas econômicas adotadas pelo Brasil, no passado, por meio do tabelamento dos preços internos, do controle quantitativo, das atividades de exportações e de importações, da combinação de impostos e de subsídios incidentes nas atividades agroindustriais e da proteção tarifária, entre outras medidas, discriminaram a agricultura (Pinheiro et al., 1994).

Entretanto, as discussões vigentes reconhecem que o Estado ainda desempenha papel importante na orientação das atividades econômicas. As divergências situam-se nos graus de intervenção considerados ideais a cada situação.

Portanto, dada a importância dos efeitos das políticas de desenvolvimento econômico sobre a agricultura, é apresentada a seguir uma visão panorâmica da evolução das políticas públicas, a partir de 1980, especificamente das econômicas e agrícolas do país, as quais, segundo diversos autores ${ }^{3}$, causaram impactos sobre o setor agrícola e, consequentemente, sobre o setor cooperativista agropecuário.

\subsubsection{Os anos 80 e os tempos da superinflação}

Segundo Pinheiro et al. (1999), a década de 80 foi marcada pela estagnação do nível de atividade, por profundos desequilíbrios macroeconômicos e, em especial, pela hiperinflação. No período de 1980 a 1993, a taxa de crescimento média da economia

\footnotetext{
${ }^{2}$ OCDE - Organização de Cooperação e Desenvolvimento Econômico. Tem como objetivo principal incentivar o crescimento econômico, o alto nivel de emprego e a estabilidade financeira entre os paises membros.

${ }^{3}$ Consultar os autores: Franco, (1997); Rezende et al. (1997); Duque \& Azevedo Filho (1997); Viera (1997); Rocha \& Teixeira (1997); Nogueira \& Oliveira (1997), Gomes \& Finamore (2000) entre outros.
} 
brasileira foi muito baixa, de apenas $2,1 \%$ a.a., fazendo com que o país registrasse uma estagnação do PIB per capita entre 1980 e 1993. O crescimento do produto foi também muito irregular, alternando anos de grande expansão com outros de significativo declínio. A indústria foi particularmente atingida e sua participação no PIB diminuiu de 33,7\% em 1980 para 29,1\% em 1993.

Nesse mesmo período (de 1980 a 1993), a taxa de inflação, medida pelo IGP-DI, atingiu o patamar médio de $438 \%$ a.a. Ao mesmo tempo em que se tentava conter a inflação, iam sendo criados mecanismos que objetivavam torná-la suportável, o que acabava facilitando a sua aceleração. $O$ fracasso de uma sequêencia de planos heterodoxos de estabilização - em curto período de tempo: cinco planos em cinco anos contribuiu para aumentar a instabilidade na economia e intensificar o ritmo da inflação.

Além disso, especialmente na segunda metade da década de 80 , houve expressiva redução das taxas de investimento no país. Em 1980, a taxa de investimento a preços constantes era de 23,6\% do PIB. Em 1990, o indicador tinha caído para 15,5\% do PIB e continuou a diminuir até atingir 14\% do PIB em 1992.

As contas do setor público também sofreram severa deterioração, como conseqüência da queda das receitas em função do baixo crescimento econômico e de uma política expansionista de incentivos e subsídios fiscais.

Os déficits públicos crescentes, a dificuldade do Estado em garantir a estabilidade e a provisão de serviços básicos (educação, saúde e segurança) e o ônus imposto por sua agenda de empreendedor direto originaram, ainda na década de 80 , um processo de redefinição do papel do Estado na economia que viria a amadurecer nos anos 90 .

\subsubsection{As políticas econômicas e agrícolas durante a década de 80}

A crise da dívida externa, iniciada em 1982, foi o marco inicial de uma série de reformas que influenciaram a estratégia de desenvolvimento recente. Os países 
sobrecarregados com as obrigações dos serviços da dívida fizeram programas de austeridade, negociados com o Fundo Monetário Internacional (FMI) e com o Banco Mundial (BM), os quais incluíam reduções dos gastos do governo, diminuição da oferta monetária e desvalorização da taxa de câmbio (De Janvry et al., 1997).

Goldin \& Rezende (1993), ao descreverem a crise econômica dos anos 80, mostraram que o crescimento industrial sofreu uma derrocada, em contraste com a continuidade do crescimento agrícola. De 1980 para 1989/90, a queda na taxa de crescimento da agricultura foi mínima - de 3,8 para 3,5\% - em contraste com o produto industrial, cuja taxa de crescimento caiu de 10,1 para 2,6\%. A agricultura emergiu como o setor econômico líder, exercendo, segundo os autores, uma força estabilizadora e amortecendo o colapso no processo de crescimento da renda.

Segundo Resende Lopes (1993), de 1981 a 1985, os choques de oferta coincidiram com o fim do financiamento externo, com crises de divisas e políticas contracionistas (pelo menos na intenção), monetárias e fiscais. Houve, nesse período, também a ocupação do Centro-Oeste como forma de se ter um "estoque regulador" contra a escassez interna. O crédito, por sua vez, mostrou-se incapaz de fomentar a produção interna, levando o governo a intervir mais ainda na comercialização. Os preços domésticos se elevaram e, em 1983, houve uma redução da oferta interna e mundial que aumentou ainda mais os preços.

Em fevereiro de 1986, as autoridades lançaram o Plano Cruzado ${ }^{4}$, cujo nome deveu-se ao da nova moeda introduzida na época. O plano incluiu uma reforma monetária, um congelamento de preços, reajuste de salários e uma substancial desindexação da economia. A correção monetária dos empréstimos rurais tinha se tornado, no início de 1986, um verdadeiro "fantasma" para os agricultores, espremidos entre a aceleração inflacionária e a quebra de safra (Goldin \& Rezende, 1993).

\footnotetext{
${ }^{4}$ Para saber mais sobre a experiência e o fracasso do Plano Cruzado, pesquisar Gremaud (2002).
} 
Os anos 80 caracterizaram-se, também, pela articulação muito próxima entre as cooperativas, as empresas multinacionais e os agentes financeiros, através de repasse de insumos e produtos aos cooperados, estimulados pela mudança ocorrida no ambiente econômico e na política agrícola brasileira. Segundo Bianco (1995), a baixa capacidade do governo em sustentar as condições e os volumes de recursos necessários aos financiamentos para a agropecuária levou esse setor, como também as instituições financeiras e as empresas do sistema agroindustrial, à busca de novas alternativas de financiamento, de mecanismos compensatórios de taxas de juros e de incremento dos investimentos privados. Portanto, a necessidade de ajustes decorrente das mudanças no ambiente econômico fez emergir novas formas de atuação das cooperativas de produção.

Cardoso (1997) relata que, após 1983, houve restrição de recursos e insuficiência de crédito para a agropecuária. Com o advento da taxa referencial e ainda com inflação elevada, acentuaram-se os riscos sobre a capacidade de pagamento dos agricultores. Como consequêencia desse processo indústrias relacionadas à agricultura passaram a financiar bens indispensáveis aos produtores. Citam-se, como exemplos, a Agroindústria Cargill Agrícola S.A. e a Cooperativa de Cafeicultores da Região de Marília (COOPEMAR).

O caso da Cargill mostra o papel preponderante de instituições não ligadas ao governo na oferta de parte dos recursos financeiros à agricultura como forma de sustentar e garantir a produção agropecuária e, consequentemente, garantir o próprio suprimento de matéria-prima para o processamento industrial. Essa alternativa independia do crédito oficial e atendia aos segmentos empresas, produtores, cerealistas e cooperativas sem interferências governamentais. Assim, ficavam assegurados para os agropecuaristas recursos necessários para a obtenção de fatores produtivos; para as indústrias, regularidade e continuidade na venda de seus produtos; e para os bancos, garantias adicionais e menor risco de inadimplência por parte dos agricultores (Bianco, 1995). 
Portanto, com a crise dos anos 80 , a assistência governamental à agricultura reduziu-se enormemente. Pesquisa, extensão rural e créditos para investimentos foram os itens mais prejudicados. Foram reduzidas também as linhas de crédito de curto e médio prazos para o custeio e comercialização. Todo esse processo de encolhimento da ação pública no setor agrícola acabou por transferir para o sistema cooperativista grande parte das necessidades do produtor anteriormente atendidas pelos órgãos governamentais.

Ainda no tocante a crédito rural, esse instrumento de política agrícola altamente prestigiado da década de 70 entrou em crise nos anos 80 tanto pela escassez de recursos públicos quanto pelo fim do subsídio. A incorporação da correção monetária tornou os custos financeiros inviáveis para o agricultor e contribuiu para os problemas de inadimplência registrados. As mudanças nas regras de indexação decorrentes dos sucessivos planos de estabilização foram outro agravante do impasse que se manteve nos anos 90.

Essas evidências indicavam que a orientação governamental em buscar um novo padrão de financiamento para a agropecuária fez com que gradativamente os recursos destinados à chamada agricultura empresarial ou patronal fossem obtidos em fontes alternativas, menos dependentes de apoio governamental.

Para Resende Lopes (1993), o período de 1986 a 1989 foi caracterizado pelo desastre do Plano Cruzado. O estímulo dos juros irrisórios e a forte demanda ocasionaram explosão de preços no segundo semestre de 1986; a agricultura, por sua vez, responde com grande safra em 1987. Os estoques públicos, formados através da política de preços mínimos e de importação, deprimiram os preços internos, inclusive devido aos fortes subsídios incorporados nas importações. Dessa forma, os produtores foram levados à inadimplência em massa.

Foram usados congelamentos de preços, importações subsidiadas na origem, e toda sorte de intervenções nos preços. Compras importantes nesse período da política de preços mínimos acabaram desorganizando os mercados agrícolas. Não havia ainda a 
Lei Agrícola 8.171 e muito menos os preços de liberação de estoques e as regras de administração de estoques públicos. Esse período é marcado pela coincidência dos planos de estabilização com a escassez interna e como tentativa de administrar o mercado agrícola, é adotado o controle de preços internos.

Dias \& Amaral (1999), ao analisarem as mudanças estruturais ocorridas na agricultura brasileira durante as décadas de 80 e 90, apontaram os anos de 1987 a 1992 como o período em que se concentraram as reformas mais relevantes para a agricultura. Segundo os autores, foram três os grupos mais importantes de reformas: 1) as destinadas a eliminar barreiras ao comércio exterior; 2) as voltadas para a estabilização dos preços domésticos; e 3) as institucionais destinadas a desativar os monopólios estatais na agricultura.

As reformas no comércio exterior envolveram mudanças nas regras de importação de produtos e insumos, com a redução dos níveis tarifários, redução na dispersão e harmonização da estrutura tarifária. Envolveram a eliminação de proibições para importar e exportar e modernização dos procedimentos operacionais em alfândegas e agências controladoras do câmbio. Incluíram também a extinção de impostos, simplificação de normas, eliminação de guias e licenças prévias e outras mudanças.

$\mathrm{Na}$ reforma dos mercados domésticos, criaram-se mecanismos de intervenção mais consistente com o funcionamento dos mercados, alinhando os preços mínimos com o mercado internacional, instituindo o sistema de pagamento pela diferença entre o preço mínimo e o de mercado sem as compras governamentais. Essas medidas trouxeram transparência e melhores condições para atrair agentes privados para carregar estoques e ampliar os mercados agrícolas.

No que tange à desativação de monopólios estatais, as reformas se deram na direção de reduzir o papel governamental na economia, transferindo para a iniciativa privada a comercialização de produtos cujo controle ficava antes integralmente nas mãos do estado. Os casos mais importantes são os do açúcar e álcool, do café e o do trigo. 


\subsubsection{A agricultura brasileira nos anos 90: o impacto das reformas de políticas}

O ambiente macroeconômico no início da década de 90 influenciou na determinação das reformas que afetaram o setor agrícola. A liberalização do comércio, a desregulamentação de mercados agrícolas e as mudanças no crédito rural e na política de preços mínimos foram medidas adotadas como parte de uma estratégia global para combater a ameaça de hiperinflação.

Os planos de estabilização, na prática, causaram instabilidade para o setor agrícola, uma vez que eram quase sempre acompanhados por profundas crises financeiras. Isso aconteceu em 1986-87 (Plano Cruzado), 1989 (Plano Verão) e em 1990-91 (Planos Collor I e II). A instabilidade se manifestou por meio de ciclos de preços nos mercados de ativos agrícolas (terra e gado, principalmente), bem como nos mercados de "commodities" agrícolas. A menor atratividade dos ativos financeiros, que acompanhou o lançamento desses planos, fez com que os preços de terra, estoque de gado e "commodities" agrícolas crescessem. Isso, por sua vez, proporcionou aumento na tomada de empréstimos e nos investimentos na agricultura. Porém, quando esses planos falharam, os ativos financeiros voltaram a ser mais atraentes. A conseqüência foi uma súbita queda dos preços de ativos reais e "commodities" agrícolas e profundos problemas para o setor (Helfand \& Rezende, 2001).

Em geral, o dilema da liberalização agrícola, nos anos 90, é que ela ocorreu num contexto adverso de queda dos preços internacionais, apreciação da taxa de câmbio real, altas taxas de juros e queda dos subsidios.

Segundo De Janvry et al. (1997), as reformas agrícolas, na última década, podem ser caracterizadas como um "processo de racionalização" de política setorial com política macro, isto é, do cancelamento de programas de governo e políticas na agricultura que não poderiam ser justificadas sob o paradigma de livre mercado. O papel do governo é limitado à promoção e regulamentação de mercados livres e competitivos e à provisão de bens e serviços nas instâncias em que os mercados falham, como em casos de bens públicos, monopólios naturais, informação assimétrica e economias de escala. 
A partir de 1990, a queda dos preços dos produtos agrícolas aliada à escassez dos recursos de crédito rural institucional e às taxas de juros praticadas em nível das de mercado levaram cooperativas agropecuárias a enfrentar problemas de inadimplência. De 1990 a 1992, na administração do presidente Collor, o país experimenta o fim da política de substituição de importações com a abertura do comércio, aprovação das leis agrícolas, imposição de regras que disciplinaram o governo na intervenção dos mercados agrícolas e com a liberação do comércio de produtos agrícolas que começava a produzir seus primeiros frutos a partir de 1990.

A sobrevalorização cambial, nesse período, atinge o apogeu (1990/1991). Sucessivas tentativas de liberação dos mercados agrícolas ocorrem nesse período, inclusive com a privatização da comercialização do trigo, mas ainda há controle de preços - Plano Collor I. (Resende Lopes, 1993).

A queda ocorrida no crédito rural no início dos anos 90 deveu-se, em parte, ao aumento da inadimplência agrícola em 1989 e, de novo, em 1990, uma vez que a não devolução do capital restringiu a disponibilidade de fundos para empréstimos novos. Entretanto, a maior parte da queda foi conseqüencia do Plano Collor que restringiu os recursos do Tesouro e tornou indisponíveis fundos que eram antes emprestados à agricultura, como a poupança rural, que contraiu-se em $78 \%$ entre 1989 e 1990 (Rezende, 2001).

A crise de escassez de alimentos do final de 1991, que resultou de duas quebras de safras sucessivas, em 1990 e 1991, levou o governo a reativar a política de preços mínimos e a expandir o crédito rural para o ano agrícola 91/92 (Rezende, 2001). O mesmo autor mostra as contradições dessa volta da política agrícola tradicional, sobretudo em face das restrições de recursos e da maior abertura comercial. A conseqüência foi um total atrelamento da Política de Garantia de Preços Mínimos (PGPM) ao crédito de custeio e uma retenção demasiadamente longa dos estoques, implicando custos elevados. 
Durante boa parte da primeira metade da década de 90, o Brasil teve inflação elevadíssima e crescente; déficit fiscal, taxa de câmbio bastante desvalorizada - reflexo ainda da crise da dívida dos anos 80 , em que o crédito externo tinha desaparecido -, situação externa folgada, representada por uma conta corrente que, na média de 1991-93, foi superavitária e ainda pela entrada de capitais que fez com que o volume de reservas internacionais, que tinha fechado em 1990 e também em 1991 em menos de US\$ 9 bilhões, aumentasse a partir de 1992, atingindo mais de US\$ 40 bilhões quando do lançamento do Plano Real (Pinheiro et al., 1999).

Quanto ao comportamento do mercado de trabalho, durante o período de 1990 a 1994, ocorreu uma queda do emprego industrial e aumento do emprego nos setores de comércio e de serviços, que acompanhou a evolução do nível de atividade na economia (Camargo et al.,1999).

\subsubsection{As políticas econômicas e agrícolas a partir de 1994}

O Plano Real foi lançado em fins de junho de 1994, depois do fracasso dos cinco programas de estabilização anteriores, desde 1986. Tais planos tiveram como característica comum o congelamento de preços, que levava a uma queda imediata da inflação, com posterior aceleração da taxa de crescimento dos preços, conduzindo a uma roda hiperinflacionária. O principal êxito do Plano Real foi a eliminação desse maior problema da economia brasileira até 1994.

Observou-se, uma política fiscal expansionista, paralelamente a uma política monetária contracionista, que serviu inicialmente ao objetivo de estabilizar os preços, controlando a forte expansão do consumo após a queda da inflação. Mas durante o plano, essas políticas passaram a ser comandadas pela necessidade de remunerar adequadamente os capitais a que o país recorreu para financiar seu déficit em conta corrente e de rolar as amortizações da dívida externa, mantendo os juros altos para compensar a deterioração do risco-país (Pinheiro et al., 1999). 
Segundo Dias \& Amaral (1999), o Plano Real apresentou o melhor desempenho entre todos os Planos de estabilização anteriores. A inflação foi contida com a eliminação dos mecanismos de indexação e a memória inflacionária foi sendo apagada nesse período. Todavia, segundo esses autores, começaram a se acumular problemas relacionados a duas variáveis básicas do sistema: a taxa de câmbio e a taxa de juros.

A taxa de câmbio sofria reajuste gradual, mas numa velocidade incapaz de evitar a valorização da moeda nacional em relação a outras moedas, abrindo espaço para um crescente déficit comercial. Para financiar esse déficit, o governo executava uma política monetária restritiva para aumentar a taxa de juros e atrair capital do exterior. Os custos dessa política de taxa de juros alta foram os encargos crescentes da dívida pública.

Nesse contexto, o descompasso entre os preços agrícolas em relação à política monetária e cambial, ocorrido durante o governo Collor, com a abertura comercial, intensificada no Plano Real, em que provocara a entrada de produtos mais baratos e, muitas vezes, subsidiados no país de origem, o que aumentou a concorrência interna, refletida em queda nos preços recebidos pelos produtores e nos preços pagos pelos produtores, desencadeia uma descapitalização extremamente severa no setor agropecuário, desembocando no processo de securitização e equalização das dívidas da agricultura, o que comprometeu o relacionamento entre as cooperativas agropecuárias, as instituições financeiras e as empresas fornecedoras de insumos. Os bancos privados não aceitaram equalizar as dívidas nos prazos permitidos pela securitização ( 5 anos) e as empresas fornecedoras de insumos, em decorrência das exigências bancárias assumiram os débitos das cooperativas. Assim, as cooperativas passam a dever não mais para os bancos, mas diretamente para essas empresas, comprometendo o limite de crédito e a capacidade de continuar atendendo aos cooperados.

Por outro lado, a equalização das dívidas junto ao Banco do Brasil e aos bancos estaduais, únicas instituições financeiras que securitizavam todos os 
financiamentos, exigiu garantias hipotecárias da quase totalidade dos bens das cooperativas, comprometendo a capacidade de obtenção de novos financiamentos por falta de garantias adicionais.

Nogueira \& Oliveira (1997) analisaram as origens do endividamento da agricultura brasileira que culminou com a crise de 1995. Mostraram que o problema se iniciou com o Plano Verão que se baseou exclusivamente no congelamento dos preços na época da safra. A partir daí, seguiram-se os Planos Collor I e II que, da mesma forma, trouxeram prejuizos para os agricultores com o novo congelamento e as dificuldades de comercialização da safra devido à redução da liquidez da economia no Plano Collor I. Com o Plano Real, a situação se agravou. Os agricultores, que já se encontravam endividados pelos resultados das safras passadas, entraram em colapso e não puderam saldar suas dívidas. Segundo os autores, muitos agricultores tiveram seus bens alienados pelos bancos e foram expulsos do processo produtivo. A principal conclusão dos autores, é que os agricultores foram penalizados pelos interesses da política macroeconômica que lutava incessantemente contra a inflação em detrimento dos interesses do setor.

Barros (1998), analisando a transição na política agrícola brasileira no período de 1987 a 1996, descreve a respeito de evidências sobre os rumos da mesma, tendo em conta as imposições e restrições decorrentes da abertura econômica e da crise fiscal.

"A grande ameaça que paira sobre o desempenho futuro da agricultura brasileira está na relativa lentidão com que se dá o processo de criação, fora do setor público, de novas alternativas de gerenciamento de riscos e de financiamento da agricultura, necessários tanto para a manutenção da atividade nos niveis desejados a curto prazo, como também para viabilizar a adoção contínua das modernas técnicas de produção" (Barros, 1998, p.19) 
$\mathrm{O}$ mesmo autor conclui objetivamente que, devido à falência financeira e operacional do Estado, a manutenção do crescimento da agricultura passa a ser gerada com base num novo tripé: a) racionalização dos gastos públicos com dispêndio seletivo voltado para a produtividade e bem-estar do homem no campo; b) liberalização comercial interna e externamente; e c) maior realismo cambial.

Houve mudanças profundas na forma de atuação do governo no crédito rural nos últimos anos dessa década. Isso partiu da constatação de que o modelo tradicional estava esgotado e apresentava vários problemas, entre os quais a excessiva participação do Estado e a cultura dos subsídios. A realidade imposta pela necessidade de controle dos gastos públicos, em decorrência da política fiscal, e o esforço de modernização do Estado foram determinantes para que se fizessem alterações substanciais no padrão de atuação governamental (Gasques e Conceição, 2001).

A principal mudança do crédito rural foi com relação às fontes de recursos, que implicou em alterações profundas na forma de atuação do governo e no redirecionamento dos recursos. Um dos resultados mais visíveis da mudança de atuação do governo foi o aumento da importância relativa de fontes alternativas de financiamento (Gasques \& Conceição, 2001). Mas, segundo Carvalho (2000), essas novas fontes de recurso e os novos instrumentos colocados em prática não constituem ainda uma resposta suficiente e adequada à promoção da retomada do crescimento da agropecuária brasileira.

Os riscos embutidos nos financiamentos agrícolas nos anos mais recentes têm dificultado o acesso dos produtores e fazem com que as instituições financeiras assumam posição cada vez mais conservadora para evitar a inadimplência. Assim, exigem mais garantias, reduzem as aplicações e insistem na cobrança dos débitos bancários. Ainda segundo a autora, a insuficiência de recursos alocados para a securitização e para a pequena adesão dos produtores ao alongamento da dívida são evidências de que a questão do endividamento rural não está sendo conduzida de forma a solucionar definitivamente os problemas de insolvência no campo. 


\subsubsection{A primeira fase do Plano Real}

Ao contrário dos Planos de estabilização anteriores, o Plano Real foi precedido por uma tentativa de ajuste fiscal e não se valeu de congelamentos de preços e salários. O principal êxito desse Plano foi a eliminação do maior problema da economia brasileira até 1994.

Logo após a reforma monetária de junho de 1994, as autoridades permitiram a valorização do câmbio real, supondo que os déficits elevados nas contas correntes pudessem ser financiados com os fluxos internacionais de capitais. Investiram na defesa do regime cambial no intuito de cumprir a meta de inflação baixa. O estímulo ao ingresso de capitais, para financiar os déficits em conta corrente, requeria juros reais elevados, o que impunha uma limitação ao investimento e, portanto, ao crescimento econômico sustentado.

Deve-se observar também os três choques externos que ocorreram entre os anos de 1994 a 1998 - o mexicano em 1994-95, o do sudeste asiático, ao final de 97, e o russo, no segundo semestre de 98. Esses choques provocaram fortes fluxos de saídas de capitais, que obrigaram a elevação dos juros reais para defender a taxa cambial. Os choques de juros reais conduziram a quedas adicionais de crescimento econômico e ao aumento do déficit público, agravando a não sustentabilidade do crescimento da divida pública (Pereira, 1999).

Quanto aos problemas com o setor externo, a apreciação do câmbio, no início desse período, com a abertura comercial acarretaram, por um lado, queda da inflação mas, por outro, esteve associada à deterioração das contas externas do país. A ocorrência de déficits, a partir de 1994, foi desencadeada, em especial, pelo rápido crescimento das importações, uma vez que a expansão das exportações brasileiras não foi suficiente para compensar o aumento das importações.

Durante o período de 1994 a 1998, enquanto as importações cresciam 77\%, as exportações aumentaram apenas 17\%. Apesar das exportações terem apresentado um 
ritmo significativamente inferior ao das importações, seguiram uma trajetória contínua de crescimento até 1997. No ano de 1998, porém, apresentaram uma retração de US\$ 2 bilhões. Essa queda das exportações ocorreu principalmente em função da crise financeira asiática, da queda das cotações das principais commodities no mercado internacional e do desaquecimento da economia mundial (Pinheiro et al., 1999).

Quanto à situação das contas públicas, no conceito operacional, no primeiro mandato do presidente Fernando Henrique Cardoso, ocorreu uma piora. As necessidades de financiamento do setor público passaram de 0,4\% do PIB no período de 1991 a 1994 para 5,2\% no período de 1995-1998. Esse fato decorreu não só do crescimento das despesas com juros reais - que passaram nesse mesmo período de comparação de $3,3 \%$ do PIB para 5\% - mas, principalmente, da evolução do déficit primário, que passou de superávit de 2,9\% no período de 1991 a 1994 para déficit de $0,2 \%$ de 1995 a 1998 (Pinheiro et al., 1999).

Esse desequilibrio fiscal teve como conseqüência principal o rápido aumento da dívida do setor público. Em 1994, a dívida interna líquida do setor público

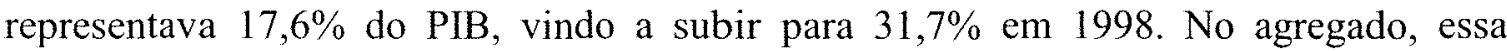
dívida atingiu 38,3\% do PIB em 1998 (Pinheiro et al., 1999).

A taxa de desemprego seguiu uma trajetória acedente na segunda metade da década de 1990, passando de uma média anual de 4,6\% em 1995 para 7,6\% em 1998. Sabe-se que os determinantes que geralmente afetam o nível de emprego são o custo da mão-de-obra, o processo tecnológico e a situação conjuntural da demanda. Como a legislação trabalhista (componente do custo da mão-de-obra) não se tornou mas rígida nos últimos anos da década de 1990, é pouco provável que ela seja a causa principal do aumento do desemprego depois de 1995.

Com a abertura comercial, a estabilidade dos preços e a valorização do câmbio, o custo relativo do capital caiu, estimulando a substituição de mão-de-obra por máquinas e, finalmente, o mercado de trabalho sofreu, com particular intensidade, os efeitos da retração da economia brasileira nos períodos mais recentes. É compreensível 
que o desemprego tenha subido em 1996-97, quando a taxa média de crescimento da economia caiu de 5\% a.a. no início dos anos de 1990 para 3,2\% em 1997, aumentando mais ainda em 1998 (Pinheiro et al., 1999). Isso mostra que, a evolução do nível de demanda da economia brasileira tornou-se o determinante principal da trajetória das taxas de desemprego nos últimos anos da década de 1990.

Resumidamente, o que ocorreu com a evolução dos indicadores macroeconômicos tradicionais, nessa primeira fase do Plano Real foi: o crescimento econômico foi moderado e a taxas declinantes; o desemprego subiu; o endividamento público aumentou a uma maior velocidade; o setor externo caracterizou-se pelo baixo crescimento das exportações; e elevados déficit em conta corrente.

Mas é inegável que a estabilidade representou melhoria substancial com relação ao cenário experimentado pelo país de 1980 a 1993. Destacam-se também o aumento da taxa de investimento, que passou de 14\% do PIB em 1992 para 17,5\% em 1997-98, o aumento da produtividade da indústria e a transformação do Brasil em um dos destinos mais importante dos fluxos de investimento estrangeiro direto no mundo (Pinheiro et al., 1999).

\subsection{As políticas agrícolas e o cooperativismo}

O desenvolvimento do cooperativismo agropecuário no Brasil foi impulsionado pelo processo de modernização da agricultura, bem como pela organização dos produtores com o apoio do governo federal.

O governo se empenhou em medidas que alavancassem não somente as cooperativas agropecuárias, mas a agricultura, no sentido de promover o desenvolvimento agrícola do país. As principais medidas de suporte à política agrícola do governo foram: o Sistema Nacional de Crédito Rural (SNCR), a política de garantia de preços mínimos e alguns subsídios a culturas de exportação, como trigo e soja, somando a esses incentivos a disponibilidade de recursos financeiros a um custo ínfimo. 
A política de crédito agrícola incentivou a agricultura, mas também gerou benefícios substanciais à indústria de transformação, uma vez que mais da metade do crédito rural concedido foi de curto prazo para custeio, alavancando, assim, as compras de fertilizante e de outros insumos (Dornelas, 1998).

O programa de preços mínimos lançado em 1943 com a criação da Comissão de Financiamento da Produção (CFP) só começou a ser aplicado em 1946 em seis culturas, inicialmente - arroz, feijão, milho, amendoim, soja e semente de girassol -, estendendo-se mais tarde a 42 produtos. Graças a essa política, os agricultores ganharam a opção de vender seus produtos ao mercado ou, pelo preço mínimo, ao governo, que então realizava uma aquisição do Governo Federal (AGF) (Dornelas, 1998).

Com todo esse aparato de incentivos e apoio creditício à agricultura, o cooperativismo esteve vinculado a uma fase de facilidades e estímulos à modernização.

Nas décadas de 70 e 80 , as cooperativas agrícolas buscaram a verticalização produtiva, sendo que grande número delas atingiram a horizontalizaçâo, como forma de incorporar outras atividades de comercialização, como supermercados e outros. A verticalização é atuação de uma empresa em mais de um estágio do processo produtivo, o que freqüentemente ocorre por meio da fusão de várias empresas que atuam em estágios diferentes. O mais abrangente tipo de verticalização ou integração vertical é o da empresa que controla desde a produção da matéria-prima até a confecção final do produto. Portanto, as cooperativas que se dedicam à agroindústria apresentam esse aspecto positivo da verticalização, que é a sua capacidade de coordenar o sistema produtivo onde atuam, exercendo controle desde a fonte de matéria-prima, passando pelo fornecimento de insumos, gerenciamento de produção e marcas, até chegar ao consumidor final. Já a horizontalização é o processo ocasionado pela fusão de duas ou mais empresas que operam no mesmo estágio e com os mesmos produtos. A integração horizontal pode permitir que as empresas ganhem em termos de economia de escala e diminuam a concorrência, conquistando faixas maiores do mercado. Segundo Panzutti (1997), como estratégia de crescimento, a empresa cooperativa privilegia a 
horizontalização, pois suas atividades dependem exclusivamente de sua clientelaproprietária, que é seu mercado "cativo", procurando aumentar cada vez mais sua área de atuação, implantando postos de serviços e, como desdobramento, diversificando suas atividades. A diversificação também foi impulsionada pelas facilidades de recursos financeiros e de apoio creditícios do governo. Muito embora esses fatores tivessem permitido o crescimento do escopo de atuação das cooperativas, no final da década de 80 e limiar da década de 90, o problema rural - e dos agricultores - tornou-se um problema das cooperativas, que se encontravam altamente endividadas.

Entretanto, segundo Rodrigues (2000), ocorreu uma redução oscilante do número de cooperativas no Brasil, a partir de 1970. Segundo a autora, foi em decorrência de processo de fusão, incorporação e aquisição. Por um lado, esse processo foi estimulado pela maior flexibilidade da legislação cooperativista a partir de 1971 e por seu reforço com a Constituição de 1988 e, de outro, pelas exigências competitivas impostas pela abertura comercial brasileira e pela globalização da economia.

Segundo Dornelas (1998), as facilidades de crédito e intermináveis repasses transformavam-se na década de 90 em um enorme endividamento, resultado do comportamento oportunista dos cooperados e também dos dirigentes, que se aproveitavam de vantagens comerciais permitidas pelos tempos de inflação.

O grau de endividamento mediano nas empresas que integram as 100 maiores sociedades anônimas em 1994 era de 0,60, patamar considerado confortável. Em 1996 subiu para 0,80 e em 1997, para 0,98, ou seja, para cada unidade de capital próprio, 0,98 era capital de terceiros. No caso das cooperativas, o grau de endividamento mostrou uma situação mediana de 1,23 em 1997, revelando um aumento acentuado da participação do capital de terceiros (Campelo Jr., 2000).

Nos anos 90, com a consolidação do Mercosul e a globalização dos mercados, as cooperativas, começaram a sofrer com os diferencias internos de preços que a concorrência acirrada tinha propiciado após a abertura comercial. Elas tiveram que rever sua importância no mercado segundo o fim a que realmente se propunham. Muitas 
delas conseguiram se adaptar ao novo cenário sinalizado pela economia brasileira através de mudanças na conduta do Estado, como o corte de apoio creditício e de subsídios, as medidas de estabilização de preços e o aumento das taxas de juros reais. Mas, a maioria das cooperativas não foi bem-sucedida nesse novo cenário econômico (Dornelas, 1998).

A partir de 1994, com o fim da inflação, as cooperativas tiveram de rever sua situação contábil e controlar mais seus custos operacionais e financeiros, já que os preços passaram a ser pressionados pela ação da concorrência externa. Além disso, as cooperativas começaram a perceber que seu endividamento real era maior do que aquele camuflado sob a inflação em anos anteriores.

A gravidade refletida nesses dados e o reconhecimento do impacto das politicas oficiais para o setor rural fizeram com que o governo criasse o Recoop, Programa de Revitalização das Cooperativas Agropecuárias Brasileiras, que busca a restruturação do setor e o refinanciamento das dívidas.

\subsubsection{A criação do Programa de Revitalização das Cooperativas Agropecuárias Brasileiras - RECOOP}

Em função das dificuldades enfrentadas pelo setor cooperativista agropecuário, no Brasil, foi necessário o estabelecimento de uma política pública específica: o Recoop. Esse programa foi implementado através da medida provisória $\mathrm{n}^{\circ}$. 1.715, de 03/09/1998, com a finalidade de reestruturar e capitalizar essas cooperativas, visando ao seu desenvolvimento auto-sustentado em condições de competitividade e efetividade, através de modificações gerenciais, fusões, profissionalizações do quadro dirigente e refinanciamento de passivos que resultassem na manutenção, geração e melhoria de emprego e renda.

O ponto culminante que levou à criação do Recoop foi a elevada concentração de endividamento das cooperativas, que se agravou com as altas taxas de juros de mercado, comprometendo a solvência do segmento. O Recoop também surge 
como um instrumento de reestruturação do segmento cooperativista agropecuário objetivando o cooperativismo mais profissional e competitivo.

Para que houvesse o enquadramento da cooperativa no Recoop, a mesma deveria apresentar um plano de desenvolvimento cooperativo que contemplasse cinco projetos: 1) Projeto de Reestruturação, demonstrando a viabilidade técnica e econômicofinanceira da cooperativa; 2) Projeto de Capitalização; 3 ) Projeto de Profissionalização da Gestão Cooperativa; 4) Projeto de Organização e Profissionalização dos Cooperados e 5) Projeto de monitoramento do Plano de Desenvolvimento da Cooperativa. Esse plano de desenvolvimento envolve o equacionamento das dívidas junto aos bancos $\mathrm{e}$ fornecedores, alocação de recursos novos para redimensionamento das atividades, adequação administrativa e operacional, recuperação dos recebíveis dos cooperados inadimplentes, bem como o monitoramento do próprio plano (Bianco et al., 1998).

Com relação à aplicação dos recursos ou alongamento de dívidas, o Recoop permitia às cooperativas algumas alternativas, de acordo com o estabelecido no Anexo ao Decreto $\mathrm{n}^{\mathrm{o}}$. 2.936, de 11/01/1999, e respeitados os itens e valores da carta-consulta aprovados pelo Comitê Executivo.

As alterntivas para o alongamento de dívidas: envolvia as cotas-partes e securitização e, alongadas ou em via de alongamento com base nas disposições da Resolução CMN/BACEN n ${ }^{\circ}$ 2.471, de 26/02/1998, e nas alterações posteriores a critério da cooperativa, admitindo o financiamento com recursos do Recoop do valor necessário à aquisição dos correspondentes títulos do Tesouro Nacional.

Quanto ao pagamento de dívidas da cooperativa, após a negociação de descontos com os respectivos credores, podiam ser provenientes da aquisição de insumos agropecuários, dívidas com cooperados; dívidas fiscais; dívidas trabalhistas e encargos sociais ou, outras dívidas existentes junto ao sistema financeiro;

As cooperativas tinham também como alternativas de aplicação dos recursos, o financiamento de recebíveis de cooperados, o capital de giro voltado para o foco principal de atividades da cooperativa e investimentos como a reestruturação e 
reconversão de atividades, a verticalização e modernização tecnológica, aquisição de bens móveis e/ou imóveis e assunções de ativos por desmembramento, fusões, incorporações e desmobilizações de cooperativas de produção agropecuária.

O Anexo ao decreto $n^{\circ} 2.936$ estabelece ainda as condições operacionais do Programa, dentre as quais pode-se destacar, o prazo: até 15 anos, exceção feita às operações de capital de giro (até dois anos) e securitização (ampliação para 10 anos dos prazos das operações securitizadas); e os encargos financeiros: IGP-DI $+4 \%$ a.a. (com exceção das operações de capital de giro, com encargos fixos de $8,75 \%$ e das operações de securitização, onde se mantém a título de encargos financeiros a variação dos preços mínimos $+3 \%$ a.a.).

Quanto a carência, 24 meses para a parcela de capital, acrescida da variação do IGP-DI e de seis meses para a parcela de juros, quando se tratar de recursos para quitação de dívidas com o sistema financeiro, com cooperados e oriundas da aquisição de insumos agropecuários, de tributos e de encargos sociais e trabalhistas, bem como para financiamento de recebíveis de cooperados. Quando se tratar de crédito para investimentos sob a égide do Recoop, a operação terá carência de prazo equivalente ao da maturação do empreendimento previsto no projeto aplicável a capital e a encargos financeiros, os limites de apoio: até R \$ 2.100.000.000,00 (dois bilhões e cem milhões de reais), destinados a financiar os itens do Recoop, exceto para alongamento de operações de cotas-partes e securitização e, também, para operações lastreadas com recursos dos Fundos Constitucionais (FNO, FNE, e FCO) e do Fundo de Defesa da Economia Cafeeira (FUNCAFÉ).

Pagamento de dívidas da cooperativa (trabalhistas, provenientes de obrigações físcais e sociais, com cooperados e provenientes de aquisição de insumos agropecuários) existentes em 30/06/1997 e ainda não pagas: os recursos necessários para o pagamento das respectivas dividas.

Obrigações bancárias e recebíveis de cooperados, originários de créditos constituídos até 30/06/1997: saldo devedor existente em 30/06/1997 atualizado até 
30/06/1998 pelos encargos financeiros pactuados para situação de normalidade e, a partir de 01/07/1998 até a data da efetiva formalização dos novos instrumentos de crédito, TR + juros de até $12 \%$ a.a. ou os encargos financeiros pactuados para situação de normalidade, o menor desses dois parâmetros (exceção feita a obrigações bancárias com recursos de captação externa: variação cambial + juros de até $12 \%$ a.a ou taxa pactuada no contrato, se inferior e, no caso de operações de repasse do BNDES: encargos financeiros pactuados para situação de normalidade).

Investimentos fixos: $50 \%$ do ativo total ou $200 \%$ do patrimônio líquido, o menor desses dois valores. Para o capital de giro: $15 \%$ do ativo total da cooperativa.

A regularização de todas as obrigações fiscais, tributárias, sociais e trabalhistas e a desmobilizações de ativos que não estejam dentro do objeto principal da sociedade, são também condições operacionais estabelecidas no Anexo ao decreto $\mathrm{n}^{0}$ 2.936 .

Não se enquadram no Recoop as operações de repasse a cooperados, excetuando-se as de cotas-partes, por traduzirem obrigações específicas de cada um desses recebedores dos recursos repassados.

Menegário (2000) destaca que, após a publicação do Decreto $n^{0} 2.936$, várias alterações foram implementadas através de Decretos, Portarias, Resoluções BACEN e reedições da Medida Provisória que dispõe sobre as normas do Programa. O mesmo autor, ao descrever essas alterações, conclui que as particularidades de cada Plano de desenvolvimento, com relação à destinação dos recursos, situação econômico-financeira e principais atividades desenvolvidas pelas cooperativas enquadradas, revelam a natureza complexa do Programa e as dificuldades que vêm sendo encontradas na sua operacionalização.

No entanto, essa injeção de novos recursos traz um impacto significativo para a sociedade como um todo, além de um custo econômico e social também alto. A utilização desses recursos exige por parte das cooperativas uma responsabilidade 
imensa, sob pena de colocar em descrédito todo o segmento. Isto é, caso o Recoop atinja seus objetivos, haveria melhoras como, por exemplo, aumento do nível de renda dos cooperados e, também, da comunidade da qual fazem parte. 


\section{CARACTERÍSTICAS DO SETOR CAFEEIRO E POLÍticAS GOVERNAMENTAIS}

Os objetivos deste capítulo são dar uma visão geral do mercado de café, abordar os aspectos produtivos desse produto no Brasil e em Minas Gerais e fazer uma breve retrospectiva dos mecanismos de intervenção do governo nesse mercado bem como das políticas que influenciaram esse setor, tais como política de crédito, de preços, de importação de fertilizantes, política cambial e assistência técnica.

\subsection{O Sistema Agroindustrial (SAG) do Café}

O café foi introduzido no Brasil em 1727 por Francisco Mello Palheta, trazido da Guiana Francesa.

Quanto à distribuição da produção no país, em 1859, o Rio de Janeiro participava com 78,40\%, São Paulo, com 12,13\%, Minas Gerais, com 7,18\%, Espírito Santo, com 1,39\% e Bahia, com 0,26\%. Entre 1961 a 1975, o Paraná assumiu a liderança da produção nacional em função da colonização agrícola (46\%). A partir de 1975 houve um direcionamento de plantio para o estado de Minas Gerais através do Plano de Renovação e Revigoramento de Cafezais (PRRC). De 1980 até os dias atuais, Minas Gerais mantém a liderança da produção nacional, contribuindo atualmente com 47,94\% do volume produzido no país.

Por certo, o sistema agro-industrial (SAG) do café é um dos mais tradicionais e significativos na geração de receitas com exportação para a economia brasileira. Em 1998, foi responsável por 5\% do total das receitas de exportações brasileiras, o que significou US $\$ 2,6$ bilhões de divisas; em 1999, correspondeu a 5,12\% 
do total das receitas de exportação brasileira, atingindo US $\$ 2,46$ bilhões de divisas; e, no ano de 2000 , participou com 3,23\% no total de receitas de exportações brasileiras, significando US $\$ 1,78$ bilhão de divisas.

Apesar desse resultado favorável, a participação do Brasil no mercado internacional do café tem sido decrescente. Na década de 60, o Brasil chegou a deter mais de $40 \%$ do total da produção mundial de café, ao passo que nos anos 90 sua participação esteve ao redor de $20 \%$. As exportações brasileiras de café nos últimos 30 anos não têm conseguido ultrapassar em média, o patamar de 25 milhões de sacas. Em parte, esse resultado se deve à conjuntura bastante adversa que o sistema enfrentou nesse período, tais como diminuição da oferta, decorrente de geadas, e endividamento geral. De outra parte, os sistema enfrenta também perda de competitividade decorrente da baixa capacidade de coordenação dos agentes do sistema para se adequar às novas regras do mercado (Saes, 1999). Já segundo Rezende et al (2000), essas reduções da participação do café brasileiro no mercado foram causadas, de um lado, pela intervenção do governo na comercialização do produto, como a sustentação de preços elevados artificialmente e, por outro, pela negligência do setor privado no estabelecimento de políticas adequadas de melhoria de qualidade, de agregação de valor ao produto e de marketing.

Além de sua importância na geração de divisas, a cafeicultura nacional empregava diretamente, em 1988, quatro milhões de pessoas e, indiretamente, seis milhões, quando considerados os demais segmentos do setor como comércio, indústria e serviços (Caixeta, 1989).

\subsection{Políticas econômicas na cafeicultura brasileira}

$\mathrm{Na}$ atividade cafeeira, em particular, o governo brasileiro interveio com o estabelecimento de diversas políticas, tais como: controle de produção, preços de garantia, preços mínimos de registro, cotas de contribuição e a intervenção do Instituto 
Brasileiro do Café (IBC) no mercado internacional, de modo a permitir aumento no valor das exportações desse produto, procurando mantê-lo como gerador de divisas.

As políticas de interesse geral do país afetaram a atividade cafeeira a exemplo da política cambial, que interferiu nos preços recebidos pelos produtores e nos preços pagos aos insumos importados utilizados na produção, como fertilizantes e defensivos (Logato, 1994).

A magnitude dos reflexos dessas intervenções variou com a expressividade do café no contexto da economia do país, sendo maiores ou menores na proporção em que o café apresentava maior ou menor participação nas exportações brasileiras (Caixeta, 1987).

Em contraste com políticas discriminatórias, outros programas foram implementados para compensar parte dos efeitos negativos dessas políticas. O Programa de Crédito Rural canalizou recursos para a cafeicultura a taxas de juros subsidiadas, por intermédio dos Planos de Renovação e Revigoramento dos Cafezais (PRRC), durante o período de 1969/70 a 1980/81, através dos créditos de comercialização, custeio e investimento.

O Programa de Crédito Rural (PCR) foi um dos instrumentos mais utilizados pelo governo nesse processo de compensação. A geração e difusão de inovações tecnológicas intensificadas após 1971 seriam também uma forma de compensar a agricultura das taxações impostas pelas políticas comerciais via redução dos custos de produção, que poderiam aumentar o lucro da atividade financiada (Blumenschein, 1982).

Para manter o equilíbrio entre oferta e demanda do café, o governo federal estabeleceu, a partir de 1969, o Plano de Renovação e Revigoramento dos Cafezais (PRRC). O Plano incluía financiamento para formação de mudas, plantio, podas, aquisição de fertilizantes e defensivos, aquisição de equipamentos para defesa fitossanitária e melhoria da infra-estrutura nas propriedades cafeeiras, por intermédio do crédito rural abundante e altamente subsidiado. 
$\mathrm{Na}$ década de 70, adotaram-se ainda como políticas comerciais, a flexibilidade dos preços mínimos de registro, as cotas de contribuição fixa independente da desvalorização cambial e a compra de grandes excedentes de produção pelo governo (Caixeta, 1989). Além dessas políticas, medidas de incentivos foram adotadas para a geração e difusão de novas tecnologias por meio da vinculação do crédito rural à assistência técnica. Foi criado no final dos anos 70 o Sistema Estadual de Pesquisa do Estado de Minas Gerais, coordenado pela Empresa de Pesquisa Agropecuária de Minas Gerais (EPAMIG) e composto pela Escola Superior de Agricultura Luiz de Queiroz (ESALQ), Universidade Federal de Viçosa (UFV) e Universidade Federal de Minas Gerais (UFMG).

A concessão de crédito abundante e barato tornou-se insustentável com os programas de estabilização do governo. As políticas adotadas de contenção do déficit público e do crédito líquido das autoridades monetárias para a promoção dos ajustes interno e externo forçaram uma nova disciplina na administração das contas agrícolas/custeio, Empréstimos do Governo Federal (EGF), Aquisições do Governo Federal (AGF) e investimento (Lopes, 1986).

Apesar de ter sido conferido tratamento gradual à retirada dos subsídios creditícios, a particular combinação da elevação das taxas de juros nominais e a contenção do volume de crédito oficial determinaram a elevação muito rápida da taxa de encargos financeiros totais no crédito rural.

Na década de 80, em conseqüência dos planos de estabilização, verificaramse importantes mudanças na política de crédito, a saber: imposição de limitações no volume aplicado e nas variações das taxas de juros, e implementação do Plano Cruzado em 1986/87, que extinguiu a correção monetária e estabeleceu juros de 7 a $9 \%$ ao ano, em 1987-88 (Gasques e Villa Verde, 1990). As políticas econômicas adotadas pelo governo, nesse período, foram o congelamento do confisco cambial, com a alíquota sobre os preços mínimos não se reajustando às desvalorizações do cruzeiro; a indexação 
de cotas de contribuição à desvalorização cambial; e a extinção do Instituto Brasileiro do Café (IBC) (Caixeta, 1989).

Os incentivos dados à geração e difusão de tecnologia na década de 70 foram sendo gradualmente retirados na década de 80 , tanto em nível federal quanto estadual. A assistência técnica prestada pelo IBC foi sendo paulatinamente restringida, culminando com sua extinção completa. Os órgãos de assistência técnica e de pesquisa do estado de Minas Gerais também sofreram grande desestímulo por parte do governo estadual, dada a falta de recursos financeiros, o que causou o esvaziamento de técnicos de órgãos estaduais, gerando perdas irreversíveis nas pesquisas desenvolvidas pela Epamig e prejuízos nos serviços de assistência técnica prestados à cafeicultura pela Emater-MG desde 1985, em razão da falta de recursos do IBC para a execução desses serviços.

A partir de 1989, quando desmoronou a estrutura do Acordo Internacional do Café (AIC), começou a ser traçado um novo perfil para a cafeicultura, passando por importantes mudanças em seu relacionamento com os mercados externo e interno.

Em nível interno, particularmente no estado de Minas Gerais, a situação do parque cafeeiro é de declínio produtivo, resultante da confluência de diversos fatores negativos, tais como: preços não remuneradores, fim da assistência técnica do IBC, desestruturação da assistência técnica da Emater-MG, desarticulação da pesquisa da Epamig, diminuição expressiva na quantidade de insumos modernos utilizados, falta de crédito rural para investimento, crédito escasso para custeio e altos encargos financeiros.

Para Rezende et al (2000), nas duas últimas décadas, as várias mudanças que ocorreram afetaram o mercado internacional do café e acarretaram problemas para o setor no Brasil. Uma dessas mudanças diz respeito à suspensão das cláusulas econômicas do Acordo Internacional do Café, em 1989. Esse acordo consistia na fixação de cotas de exportação para os países produtores de café, objetivando o equilíbrio entre oferta e procura mundial, e na estabilização dos preços. Com a suspensão desse acordo, houve reduções nos preços externos do café. Seu rompimento possibilitou aos países produtores aumentar as exportações, colocando seus estoques no mercado externo, na 
esperança de que uma eventual renovação do Acordo Internacional do Café viesse a aumentar suas cotas de exportação. Outra mudança está relacionada à tendência internacional voltada para a qualidade dos grãos exportados. Os países concorrentes do Brasil constataram tal tendência e modificaram sua produção. O setor cafeeiro brasileiro, porém, não acompanhou tal movimento, perdendo parte de sua participação no mercado externo e desestimulando o setor, o que resultou na instabilidade da receita de exportação do produto e das importações.

Em decorrência dessas transformações, tem-se tornado cada vez mais dificil, especialmente para os pequenos produtores, entender processos como o de diferenciação e o de padronização do produto "ìn natura". A falta de conhecimento e informação dos produtores sobre essas questões dificulta a inserção do país no mercado mundial, principalmente no de cafés especiais, que cresce vertiginosamente em todo o mundo.

Minas Gerais é hoje o maior produtor de café da Brasil. Nas últimas safras, cerca de $52 \%$ da produção nacional foi colhida nas várias regiões produtoras mineiras. Algumas delas, como o sul do estado, tem uma produção superior até mesmo à da Colômbia (segundo maior país produtor mundial de café). Na verdade, além da grande produção, os "Cafés de Minas", como são denominados, têm identidade própria em razão das várias nuanças da bebida e tipo físico do grão, estando entre os melhores do mundo, com imenso potencial de conquista de novos mercados consumidores. Outra questão de mercado que se coloca é a oportunidade e a necessidade de agregação de valor ao produto, tendo em vista que a maior parte do café exportado pelo estado é em grão cru, sem nenhum tipo de processamento, fazendo perder uma excelente fonte adicional de renda.

Importante é salientar que Minas Gerais possui várias instituições que se dedicam à geração de conhecimento e de tecnologia para o agronegócio café com destaque para a Epamig, as Universidades Federais de Viçosa, Uberlândia e Lavras, sendo que essa última mantém um centro de excelência em cafeicultura, o Centro de Ensino, Pesquisa e Extensão do Agronegócio Café - CEPECAFÉ, estrategicamente 
localizado em Lavras, centro geográfico da cafeicultura brasileira e maior região produtora de café do mundo. 


\section{DESEMPENHO ECONÔMICO-FINANCEIRO DAS COOPERATIVAS DE CAFÉ DO ESTADO DE MINAS GERAIS}

$\mathrm{Na}$ primeira parte deste capítulo, encontra-se a área de estudo e a caracterização das cooperativas agropecuárias do estado de Minas Gerais e na segunda, a conceituação teórica dos indicadores de desempenho econômico-financeiro das cooperativas em análise e apresentação, interpretação e exposição gráfica dos valores relativos à análise econômico-financeira durante o período de 1980 a 2000, acompanhadas de breve discussão.

\section{1 Área de estudo e fontes de dados}

No estado de Minas Gerais, o cooperativismo é representado por mais de 800 cooperativas, com mais de 595 mil associados e, aproximadamente, 23 mil funcionários, sendo que o ramo agropecuário se destaca com a participação de $65 \%$ das receitas de todas as cooperativas (tabela 1 ). 
Tabela 1. Número de cooperativas, cooperados, funcionários, patrimônio líquido e receitas por ramo, em Minas Gerais.

\begin{tabular}{lcrrrr}
\hline \multicolumn{1}{c}{ Ramos } & $\begin{array}{c}\text { Número de } \\
\text { cooperativas }\end{array}$ & $\begin{array}{r}\text { Número de } \\
\text { cooperados }\end{array}$ & $\begin{array}{r}\text { Número de } \\
\text { funcionários }\end{array}$ & $\begin{array}{c}\text { Patrimônio } \\
\text { líquido(mil R\$) }\end{array}$ & $\begin{array}{c}\text { Receitas } \\
\text { (em R\$) }\end{array}$ \\
\hline Agropecuário & 213 & 170.747 & 12.330 & $1.455 .311,67$ & $3.988 .192,03$ \\
Consumo & 49 & 155.211 & 1.415 & $37.664,75$ & $179.677,34$ \\
Educacional & 39 & 10.338 & 399 & $12.291,25$ & $47.559,38$ \\
Habitacional & 12 & 2.424 & 03 & 227,85 & 180,44 \\
Serviços & 05 & 4.563 & 14 & $12.070,27$ & $20.359,99$ \\
Mineral & 03 & 50 & 00 & 0,00 & 0,00 \\
Crédito & 250 & 162.277 & 1.985 & $301.685,70$ & $312.434,34$ \\
Saúde & 109 & 36.341 & 2.035 & $45.265,70$ & $687.495,77$ \\
Trabalho & 178 & 52.668 & 585 & $7.070,18$ & $93.238 ., 44$ \\
Outras & 16 & 871 & 4.181 & $61.120,04$ & $785.437,92$ \\
Totais & 874 & 595.500 & 22.947 & $1.932 .707,47$ & $6.114 .575,65$ \\
\hline
\end{tabular}

Fonte: Banco de dados OCEMG em números - http://www ocemg.org.br (1999)

Como já mencionado anteriormente, Minas Gerais é também o maior estado produtor de café do Brasil desde 1980. Em 2000, representava cerca de $52 \%$ da produção brasileira, além de possuir importantes cooperativas de cafeicultores.

Em 1999, esse estado apresentou o maior número de cooperativas agropecuárias, 213, de um total nacional de 1.376, seguido por Rio Grande do Sul, com 177, São Paulo, com 140 e por Pernambuco, com 110. Das 213 cooperativas mineiras, 89 são de produção. Embora a Organização das Cooperativas de Minas Gerais (OCEMG) não tenha uma classificação precisa sobre quantas se especializaram no setor cafeeiro, é possível afirmar que uma parcela considerável está inserida nesse ramo, muitas vezes combinando atividades de produção e consumo ou diversificando sua atuação para outras áreas como frutas e laticínios. 
A análise da evolução do crédito rural para o café foi desenvolvida utilizando-se dados de crédito rural em nível de Brasil e sobre o estado de Minas Gerais, obtidos nos Anuários Estatísticos do Crédito Rural do Banco Central do Brasil (1980 a 2000).

Os dados utilizados para a análise dos resultados foram retirados de relatórios de balanços e demonstrações de resultados anuais de 1980 a 2000 das cooperativas:

a. COOXUPÉ - Cooperativa Regional dos Cafeicultores em Guaxupé Ltda.

b. COOPARAÍSO - Cooperativa Regional de São Sebastião do Paraíso Ltda.

c. COOCAFÉ - Cooperativa dos Cafeicultores da Região de Lajinha Ltda.

d. CAFEPOÇOS - Cooperativa Regional dos Cafeicultores de Poços de Caldas.

e. CARPEC - Cooperativa Agropecuária de Carmo do Paranaíba Ltda.

f. COAVAP - Cooperativa Agrícola dos Pequenos Produtores do Vale do Paraíso Ltda.

g. MINASUL - Cooperativa dos Cafeicultores da Zona de Varginha Ltda.

A amostra utilizada na pesquisa foi determinada pela acessibilidade, e pela relevância das cooperativas, selecionando os elementos pela facilidade de acesso a eles e por tipicidade, os quais foram considerados representativos dentro de uma populaçãoalvo. 
A coleta de dados foi dividida em três etapas básicas: na primeira, solicitouse da OCEMG o cadastro de todas as cooperativas agropecuárias do estado de Minas Gerais que comercializavam o café. Em uma segunda etapa, selecionaram-se as cooperativas que tiveram sua fundação em anos que antecederam a década de 1980 . Na terceira, foram feitos contatos com as cooperativas, solicitando relatórios contábeis anuais dos últimos 20 anos.

Neste trabalho, deparou-se com algumas limitações relacionadas com a coleta de dados para a geração dos resultados, tais como: a) os dados retirados dos balanços das cooperativas em análise são gerais, isto é, não são específicos da comercialização de café. Todas essas cooperativas têm o café como "foco" da empresa, mas elas trabalham também com vendas de outros produtos (fertilizantes, milho, serviços etc); b) a cooperativa MINASUL entrou com dados referentes aos anos de 1996 a 2000; a COAVAP entrou com dados referentes aos anos de 1991 a 2000; c) o valor dos contratos do crédito para o café em Minas não se refere apenas ao setor de cooperativas, mas a cafeicultores de todo o estado.

Os indicadores econômico-financeiros das cooperativas ao longo do período analisado (1980 a 2000), mostrado através da análise gráfica, levou a segmentar a análise em subperíodos. Isso foi feito devido não apenas à apresentação de comportamentos diferenciados dos indicadores analisados, mas, também, em virtude de mudanças na política econômica na década de 90 , principalmente a partir de 1994 com a eliminação da inflação.

\subsubsection{Caracterização das cooperativas agropecuárias do estado de Minas Gerais}

Em 2001, as cooperativas integrantes da amostra atuavam em torno de 150 municípios mineiros. Constituídas nos últimos 20 anos, com exceção da Cooxupé, que foi fundada em 1932, e da Cooparaíso, em 1960, todas têm o café como principal atividade econômica. Podem ser também encontrados vários artigos colocados à disposição dos associados - revenda de produtos agropecuários como fertilizantes, sais minerais, corretivos de solo e defensivos. Segundo a Organização das Cooperativas do 
Estado de Minas Gerais (OCEMG), essas cooperativas estão entre as 10 maiores em receita durante os últimos seis anos.

A Cooxupé é a segunda maior cooperativa de produção e a segunda maior exportadora de café do Brasil. Na área de insumos, é a maior revendedora de fertilizantes do estado de Minas Gerais e a maior de defensivos para a cafeicultura do país. Em 2000, participavam da cooperativa 8.400 cooperados e 1.147 funcionários com atuação nos mais diversos setores, como: armazéns, fábrica de ração, torrefação, setor administrativo, assistência técnica etc. A área de atuação da cooperativa abrange 142 municípios, sendo 18 do estado de São Paulo e os demais no sul de Minas Gerais. A participação do Cooxupé na safra brasileira no ano de 2000 foi de $8,17 \%$. Suas unidades de negócio compreendem: comercialização de produtos e insumos agrícolas, assistência técnica, armazenamento de café, torrefação, laboratório, transporte, fábrica de ração, silos de milho e outros.

A Cooparaíso também atua nos setores de comercialização de café (venda para o mercado interno e externo) e de insumos, armazenamento, na área financeira (repasse de crédito rural), em assistência técnica, laboratório, supermercado e outros. Em 2000, participavam da cooperativa 3.050 cooperados, distribuídos em 35 municípios, e 230 funcionários.

A Minasul trabalha com a comercialização de café (venda para o mercado interno e externo) e de insumos, armazenamento, na área financeira (repasse de crédito rural), em assistência técnica, plano de saúde e outros. Em 2000, o raio de atuação da Minasul alcançava 70 municípios, com a participação de 2.366 cooperados e 150 funcionários.

Em 2000, a Cafépoços atuava em 33 municípios, prestando serviços de padronização, armazenagem, comercialização de café cru em grão, tanto para consumo interno (indústrias) como para exportação (atividade esta que foi retomada em 2001) e outros atendimentos sociais aos associados. A Cooperativa tem também lojas de insumos agropecuários e veterinários para fornecimento aos seus associados, insumos 
esses conseguidos junto às empresas especializadas em produtos para a lavoura de café, tais como adubos e fertilizantes, herbicidas, fungicidas e muitos outros que ajudam na formação dos grãos. Atividade que constitui o foco principal dos negócios da Cooperativa é o café. Em 2000 participavam da cooperativa 1.734 associados e 90 funcionários.

A Coocafé, por sua vez, atua nos setores de comercialização de café (venda para o mercado interno e externo) e de insumos, armazenamento, assistência técnica, laboratório, supermercado e outros. Tem o café como atividade principal. Em 2000, participam na cooperativa 2.399 cooperados e 112 funcionários, com atuação em 29 municípios.

A Carpec atua nos setores de comercialização de café (venda para o mercado interno) e de insumos e produtos agropecuários, armazenamento de café, assistência técnica e outros. Também o café como atividade principal, juntamente com a comercialização de produtos agropecuários. Em 2000, participavam da cooperativa 1.184 cooperados e 49 funcionários. A área de atuação dessa cooperativa alcança municípios mineiros.

\subsection{Indicadores econômico-financeiros}

As cooperativas, enquanto empresas inseridas em uma economia de mercado competitiva, estão sujeitas a avaliações de desempenho por parte de seus associados, público, agente financeiro, governo e concorrência entre outros. Portanto, a análise das demonstrações financeiras fornece um ponto inicial para se compreender uma empresa, seja ela cooperativa, seja sociedade anônima (Oliveira Júnior, 1996).

Pereira (1997) observou que, no Brasil, tanto no campo teórico como prático, a ênfase dada à contabilidade das sociedades cooperativas é sobre o aspecto econômico-financeiro, seguindo muito de perto as tendências das empresas capitalistas. Isso ocorre em virtude da falta de conhecimento ou envolvimento dos contadores com a 
doutrina cooperativista e também do fato da lei $n^{0} 5.764 / 71$ prestar à contabilidade uma atenção secundária.

O uso e o cálculo de índices econômicos financeiros permitem o acompanhamento ano a ano da atividade de uma empresa, possibilitando a análise de seu desempenho, se as metas estão sendo atingidas, a tendência de seu crescimento e também a comparação com índices de outras empresas ou com índices de seu setor de atuação. Assim, segundo Matarazzo (1998), o índice financeiro serve como um alerta. Muitas vezes, um endividamento elevado não significa que a empresa esteja à beira da insolvência.

Para se comparar o desempenho e a situação de uma empresa, ao longo do tempo, deve-se utilizar uma análise por meio de índices que retratam a situação e desempenho financeiro da empresa. Ou seja, uma análise de série temporal ou interna é feita quando o analista financeiro mede o desempenho da empresa ao longo do tempo, com o objetivo de determinar se a empresa está tendo progresso, ao longo de um periodo definido.

Evidências empíricas mostram que os demonstrativos contábeis podem fornecer informações valiosas sobre o processo de deterioração dos índices financeiros e, consequentemente, a respeito da saúde financeira das organizações, podendo revelar uma possível tendência ao desequilíbrio (Gimenes \& Opaso, 2001).

A análise histórica de indicadores financeiros - além de servir para vislumbrar cenários futuros e alterá-los sempre que não estiverem consoantes com os objetivos previamente traçados pela empresa - serve para identificar os impactos de políticas adotadas no decorrer do tempo sobre as empresas.

Em linhas gerais, pode-se dividir a análise em três partes distintas e concomitantes: liquidez, endividamento e rentabilidade. Nesses três segmentos, todas as informações contábeis existentes nos demonstrativos podem ser detectadas. A liquidez mostra a capacidade de solver os compromissos; o endividamento mostra a proporção 
entre capitais próprios e de terceiros, servindo como parâmetro determinante do risco financeiro implícito nessa relação; e a rentabilidade mostra a eficiência do capital empregado.

Dessa forma, para verificar os impactos das variáveis macroeconômicas sobre as cooperativas de café, serão inicialmente calculados alguns indicadores de desempenho econômico-financeiro ao longo dos anos (1980 a 2000). A partir de material teórico baseado nas obras de Matarazzo (1998), Assaf Neto (1998) e Pereira (1993), os índices aqui selecionados estão entre os mais adequados para se interpretar a situação de uma organização sob os aspectos operacionais, financeiros, econômicos e patrimoniais.

Fully et al. (2001), utilizando o modelo Logit, constataram que, numa amostra de seis cooperativas de cafeicultores do estado de Minas Gerais, durante o período de 1994 a 1999, os indicadores giro do ativo, rentabilidade sobre vendas, endividamento total e retorno dos investimentos ativos foram importantes na explicação da ocorrência de sobras e, $86,11 \%$ das observações foram previstas corretamente.

Requejo (1997), ao verificar, também através modelo Logit, a ocorrência ou não de perdas consecutivas em uma amostra de cooperativas agrícolas do Rio Grande do Sul, com base nos indicadores de retorno sobre investimentos, endividamento, dívidas dos sócios com a cooperativa e o patrimônio líquido dos sócios, constatou que os resultados negativos em cooperativas estão relacionados com a estrutura do capital, principalmente com aquelas ligadas às medidas de eficiência e lucratividade. $\mathrm{O}$ autor destaca ainda que a ausência de monitoramento nas cooperativas agrícolas é certamente um dos maiores problemas para o sistema cooperativo no Brasil.

\subsubsection{Análise qualitativa}

A partir dos índices calculados para cada cooperativa da amostra, nos períodos analisados, foram calculados os índices financeiros médios, os quais são ilustrados nas tabelas 2 a tabela 11. Para melhor compreensão do comportamento desses 
índices ao longo dos anos, foram feitas exposições gráficas desses índices para o conjunto das cooperativas acompanhadas de breve discussão.

Segundo Negri Neto et al. (1993), a apresentação gráfica pode muito bem se transformar em uma das melhores técnicas disponíveis para algumas análises exploratórias, possibilitando a identificação de mudanças complexas das relações entre duas ou mais variáveis entre si ou através do tempo.

A média foi dividida em três períodos: de 1980 a 1989 , de 1990 a 1999 e de 1994 a 2000, período de estabilidade (após Plano Real). Essas duas décadas foram marcadas por grandes oscilações nas taxas de inflação e no produto real, medidas restritivas que levaram ao aumento das taxas de juros, a limitações de volumes de crédito rural e à redução dos gastos do governo na agricultura entre outros ${ }^{5}$. Pode-se dizer, que agricultura, a partir da década de 80 , perdeu a proteção governamental e se expõe aos mercados internacionais (abertura comercial).

Dar-se-á início à apresentação do indicador financeiro denominado Liquidez Corrente das cooperativas, objeto de análise no presente estudo.

\subsubsection{Liquidez Corrente (LC)}

Os indices de liquidez procuram medir a capacidade da cooperativa em saldar suas dívidas, comparando seus direitos realizáveis com suas exigibilidades. Apontam também a capacidade que a cooperativa possui de liquidar seus débitos de curto prazo, ou seja, dívidas de até 365 dias; seu cálculo é expresso na fórmula seguinte:

$$
L C=\frac{A C}{P C}
$$

onde:

$L C=$ liquidez corrente;

\footnotetext{
${ }^{5}$ Sobre esse assunto, ver Gremaud et al. (2002).
} 
$A C=$ ativo circulante;

$P C=$ passivo circulante.

Toda vez que o índice de Liquidez Corrente é superior a 1, significa que seus ativos circulantes estão sendo financiados por uma parcela de capital circulante líquido, ou seja, existe uma certa folga financeira a curto prazo. A interpretação desse índice é no sentido de quanto maior, melhor, mantidos os demais fatores constantes na situação econômico-financeira das cooperativas. Também pode-se dizer que índices de $L C$ superior a 1,00 significam que os investimentos no ativo circulante são suficientes para cobrir as dívidas das cooperativas de curto prazo e ainda permitem uma folga. O excesso em relação a 1 deve-se à existência do Capital Circulante Líquido.

Alguns autores afirmam que esses índices devem ser maiores que 1, outros até acreditam que uma boa $L C$ estaria refletida num índice igual a 1,50. Esse índice, na realidade, é uma boa medida de comparação para empresas do mesmo porte e setor. A tabela 2 ilustra o comportamento médio desses índices para as cooperativas da amostra durante os anos de 1980 a 2000.

Tabela 2. Índices médios da Liquidez Corrente (LC) das cooperativas de café de Minas Gerais.

\begin{tabular}{lcccccccc}
\hline Anos & Cooxupé & Cooparaíso & Minasul & Coocafé & Cafépoços & Carpec & Coavap & Média \\
\hline 1980 a 1989 & 1,17 & 1,62 & - & 1,39 & 1,22 & 1,49 & - & 1,38 \\
1990 a 1999 & 1,46 & 1,20 & 3,19 & 1,19 & 1,22 & 1,46 & 1,15 & 1,46 \\
1994 a 2000 & 1,38 & 1,26 & 2,55 & 1,26 & 1,48 & 1,37 & 1,14 & 1,50 \\
\hline
\end{tabular}

Fonte: Dados da pesquisa 
Observa-se que, das cooperativas em estudo, todas apresentaram um índice de liquidez corrente superior a 1 , isto é, todas têm uma certa folga financeira a curto prazo durante todo o período analisado. No período considerado de estabilidade (de 1994 a 2000), as cooperativas em análise apresentaram uma melhor média desse índice $(1,50)$.

Afirmar que uma cooperativa possui ótima liquidez a curto prazo porque seu ativo circulante representa o dobro do seu passivo circulante implica ignorar uma série de informaçōes relevantes. Este ativo circulante poderá ser constituído por estoque de baixa rotação e, em parte, por estoques obsoletos e invendáveis pelo valor contábil, conter duplicatas a vencer muitos meses adiantes, com algumas de difícil cobrança, e assim por diante. $\mathrm{O}$ denominador do índice representa obrigações líquidas, podendo predominar dívidas a vencer de curtíssimo prazo. A liquidez do próprio ativo circulante e a defasagem de sua realização em moeda em relação aos pagamentos para liquidação do passivo circulante não são captadas por esse índice.

Gimenes (1999), ao analisar o comportamento dos indicadores financeiros das cooperativas agropecuárias do estado do Paraná, mostrou que $50 \%$ delas apresentaram um valor da mediana de $L C$ em 1,12; apenas $30 \%$ das cooperativas apresentaram um índice de $L C$ igual ou inferior a 0,97 ; e apenas $20 \%$ possuíam índice igual ou superior a 1,62 .

Observando a figura 1, pode-se perceber o comportamento médio da $L C$ das cooperativas em análise ao longo das décadas de 1980 e 1990 . Com exceção do ano de 1985, o comportamento médio desse índice das cooperativas oscilou entre 1,0 e 1,5, de 1980 a 1995, sendo que a partir de 1996 apresentou-se em patamares superiores que os do período anterior. A elevação desse índice para 2,45 (apêndice 3) no ano de 1985, provavelmente estava relacionado com um aumento de quase $100 \%$ no valor dos estoques da Cooparaíso nesse ano, o que ocasionou uma elevação no seu ativo circulante. $\mathrm{O}$ aumento dos estoques devido a elevação de $60 \%$ no preço da saca de café 
nesse mesmo ano (apêndice 2), pode justificar o pico verificado no ano de 1985 (figura 1).

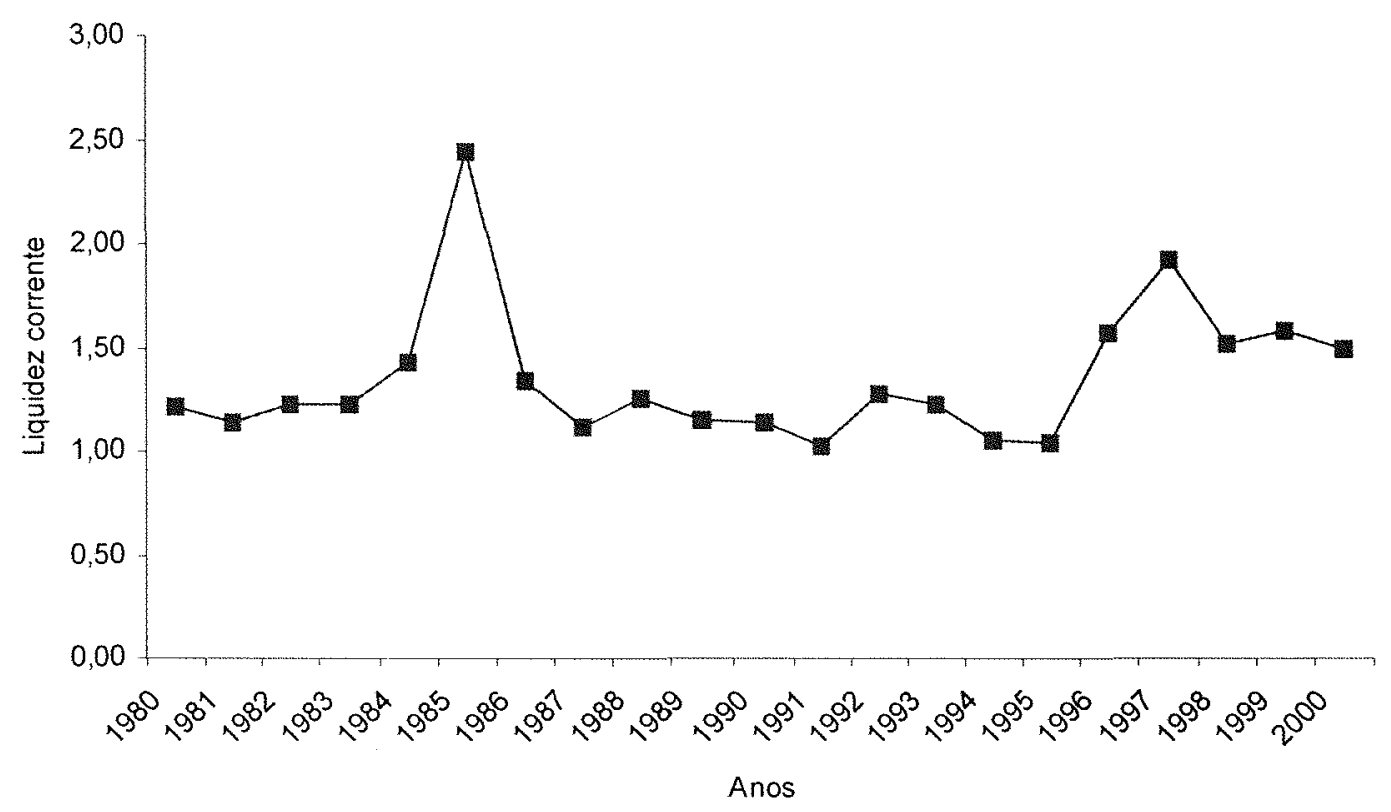

Figura 1 - Liquidez Corrente média das cooperativas de café do estado de Minas Gerais no período de 1980 a 2000.

Apesar das oscilações ocorridas durante o período analisado, esse índice indicou que as cooperativas em estudo tiveram capacidade de liquidação de seus débitos, podendo ainda liberar parte de seus ativos para os associados.

\subsubsection{Liquidez Seca $(L S)$}

Esse índice mede a capacidade da cooperativa de pagamento das obrigações de curto prazo, excluindo-se os estoques do ativo circulante. Esse indicador é mais rigoroso que os demais porque considera os estoques como sendo ativos necessários à manutenção da própria atividade operacional, não estando disponíveis para a cobertura das obrigações de curto prazo. Sua fórmula é: 


$$
L S=\frac{A C-E S}{P C}
$$

onde:

$L S=$ liquidez seca;

$A C=$ ativo circulante;

$P C=$ passivo circulante;

$E S=$ estoque

O valor ideal para esse índice é bastante diferenciado para cada organização porque depende das suas características operacionais, ou da sua capacidade de realizar os estoques. Uma queda na demanda pode também influenciar esse índice no sentido de provocar dificuldades na venda dos estoques de produtos acabados.

Deve-se ressaltar que a comparação através de índices financeiros de cooperativas com empresas de capital pode distorcer as análises financeiras devido à própria existência de estoques elevados nas cooperativas, tanto de produto agrícola como de insumos estocados para serem vendidos aos produtores associados, como é o caso das cooperativas de café. Essa situação se expressa pelos índices financeiros de $L C$ e $L S$, nos quais deve ser considerado que geralmente os estoques das empresas agropecuárias têm uma imediata liquidez.

A tabela 3 distribui a média dos índices de $L S$ das cooperativas analisadas. Os valores significam que, por exemplo, para cada $\mathrm{R} \$ 1,00$ de dívidas de curto prazo, a Cooxupé dispôs de uma média de apenas $\mathrm{R} \$ 0,80$ de ativos de curto prazo, sem considerar o valor dos estoques, durante a década de 80 . 
Tabela 3. Índices médios da Liquidez Seca $(L S)$ das cooperativas de café de Minas Gerais.

\begin{tabular}{lcccccccc}
\hline Anos & Cooxupé & Cooparaíso & Minasul & Coocafé & Cafépoços & Carpec & Coavap & Média \\
& & & & & & & \\
\hline 1980 a 1989 & 0,80 & 1,22 & - & 0,78 & 0,75 & 0,80 & - & 0,87 \\
1990 a 1999 & 1,11 & 0,95 & 2,26 & 0,85 & 0,97 & 0,96 & 0,74 & 1,10 \\
1994 a 2000 & 1,24 & 0,97 & 2,12 & 1,37 & 1,01 & 1,00 & 0,71 & 1,20 \\
\hline
\end{tabular}

Fonte: Dados da pesquisa

Pode-se observar que a média desse índice para as cooperativas em análise foi mais expressiva durante a década de 1990 que nos anos 80, sendo que a partir de 1994 apresentou um valor superior de 1,20.

Gimenes (1999), ao analisar o comportamento dos indicadores financeiros das cooperativas agropecuárias do Estado do Paraná, mostrou que 50\% apresentaram um índice de liquidez seca em torno de 0,79. Padoveze (1996) afirma que, para empresas industriais, é conveniente que esse índice assuma valores acima de 0,70. Para empresas comerciais, propõe um índice de 0,50 . No caso deste estudo, todas as cooperativas durante o período analisado tiveram um índice de liquidez seca considerado satisfatório, ou seja, não comprometem a sua capacidade de pagamento de curto e longo prazo.

A figura 2 mostra o comportamento médio desse índice das cooperativas da amostra durante os anos de 1980 a 2000 . Percebe-se que a partir de 1996, esse índice alcançou seus maiores patamares. 


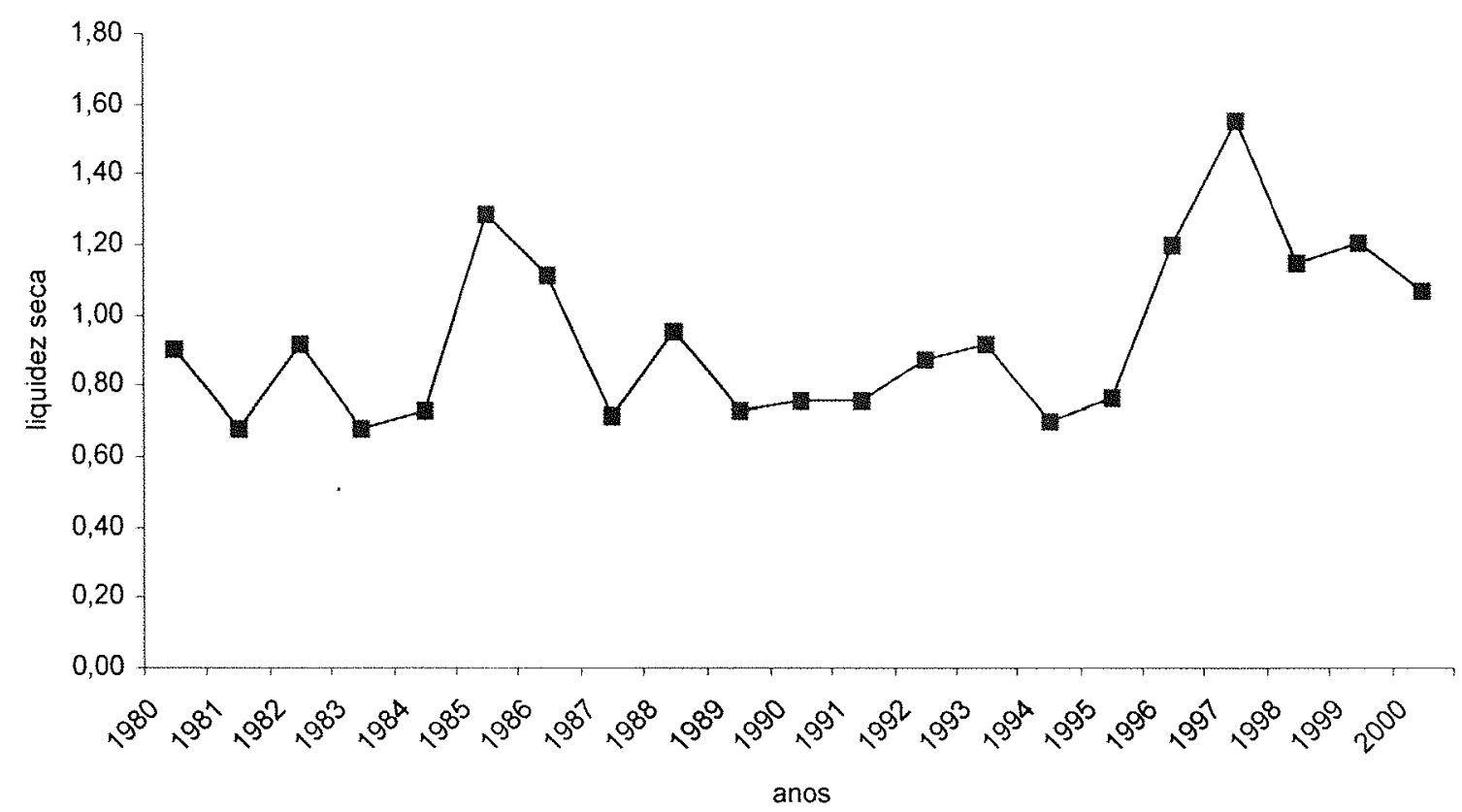

Figura 2 - Liquidez Seca média das cooperativas de café do estado de Minas Gerais no período de 1980 a 2000.

O período compreendido entre 1989 a 1994, em que ocorreram menores patamares desse índice, corresponde a um período de forte recessão na economia brasileira $^{6}$, com a adoção dos Planos Verão, no ano de 1989, Collor I, em 1990, Collor II, em 1991.

\footnotetext{
${ }^{6}$ Trata-se de uma fase marcada por grandes oscilações nas taxas de inflação e no produto real, em que ocorreu grande descontrole das contas públicas, com crescimento do endividamento interno (Gremaud et al. 2002). Segundo Nogueira e Oliveira (1997), foi a partir desse período, com os Plano Verão, Collor I e II, que se deu início ao endividamento agrícola brasileiro que culminou com a crise de 1995, quando agricultores protestaram em Brasília contra a política agrícola do presidente Fernando Henrique Cardoso.
} 


\subsubsection{Margem de Garantia (MG)}

A margem de garantia mede a capacidade de garantir o pagamento do capital de terceiros, caso a empresa venda todos os ativos. Sua fórmula:

$$
M G=\frac{A T}{P C+E X L P}
$$

onde:

$M G=$ margem de garantia;

$P C=$ Passivo Circulante; (defina se esses índices terão inicial maiúscula ou minúscula)

$A T=$ ativo total;

$E X L P=$ exigível de longo prazo.

$\mathrm{O}$ índice Margem de Garantia demonstra a capacidade que a cooperativa tem para quitar todos os débitos existentes junto a terceiros, ou seja, verifica se é possível, através da venda de todos os seus ativos, o cumprimento de todas as obrigações existentes.

Através da tabela 4, percebe-se os índices médios das cooperativas em análise durante as décadas de 80 e 90 e, especificamente, dos anos de 1994 a 2000 . Os índices obtidos indicam que, em caso de conversão de todos os bens e direitos das cooperativas, pode-se quitar todos os débitos existentes junto a terceiros e ainda oferecer garantias para cada $\mathrm{R} \$ 1,00$ a mais de dívida em cada ano. Os índices demonstram uma queda na margem de garantia durante os anos de 1990 e principalmente a partir de 1994, mas, todas se encontravam em situação considerada muito boa. 
Tabela 4. Índices médios da Margem de Garantia (MG) das cooperativas de café de Minas Gerais.

\begin{tabular}{lcccccrrr}
\hline Anos & Coavap & Minasul & Coparaíso & cooxupé & Cafepoços & Coocafé & Carpec & Média \\
\hline 1980 a 1989 & - & - & 1,34 & 1,51 & 1,66 & 2,35 & 4,22 & 2,22 \\
1990 a 1999 & 1,80 & 2,29 & 1,29 & 1,45 & 3,57 & 1,09 & 2,66 & 2,02 \\
1994 a 2000 & 1,57 & 2,29 & 1,35 & 1,44 & 3,45 & 0,96 & 2,94 & 2,00 \\
\hline
\end{tabular}

Fonte: Dados da pesquisa

A figura 3 mostra o comportamento médio desse índice ao longo das duas décadas (80 e 90). Com exceção do ano de 1985, percebe-se um comportamento mais estável ao longo do período analisado em torno de 2,00 e 2,5.

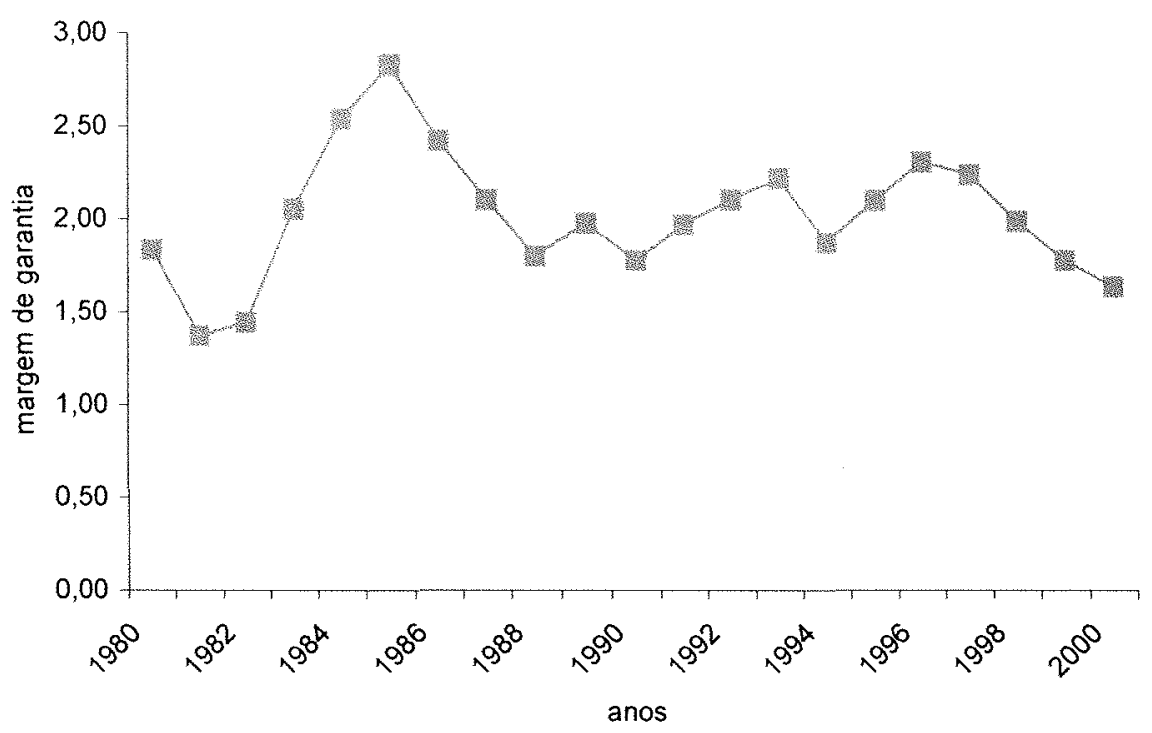

Figura 3 - Margem de Garantia média das cooperativas de café do estado de Minas Gerais no período de 1980 a 2000. 
Observando as figuras de 1 a 3 , pode-se perceber a ocorrência de pico no ano de 1985. Possivelmente, esse comportamento estaria relacionado com uma valorização média da saca de café de $60 \%$ que ocorrera nesse ano. Isto é, o preço passou em média de US\$72,75 em 1984 para US\$115,75 em 1985 (apêndice 2), ocorrendo, portanto, uma valorização de seus estoques nesse ano.

\subsubsection{Imobilização de Recursos Próprios (IRP)}

$\mathrm{O}$ indicador de imobilização de recursos próprios $(I R P)$ está relacionado à avaliação da eficiência econômico-financeira. Ele indica qual o volume de capital próprio que está comprometido com o ativo permanente da empresa. Ele é dado pela fórmula:

$$
I R P=\frac{A P}{P L}
$$

onde:

$I R P=$ imobilização de recursos próprios;

$A P=$ ativo permanente;

$P L=$ patrimônio líquido.

Quando o índice de IRP é um valor superior a 100\%, o ativo circulante não é financiado por recursos próprios, restando apenas a possibilidade de ser financiado por recursos de terceiros, o que aumenta o grau de dependência da cooperativa a este tipo de recurso. Pereira (1993) afirma que esse índice envolve importantes decisões estratégicas da empresa quanto à expansão, compra, aluguel ou leasing de equipamentos. São os investimentos que caracterizam o risco da atividade empresarial. 
Esse índice define quanto a cooperativa aplicou em ativo permanente para cada unidade monetária de patrimônio líquido. A tabela 5 mostra a distribuição média da IRP das cooperativas em análise. $\mathrm{O}$ valor médio desse índice situou-se em torno de $66 \%$ na década de 1980, ou seja, 66\% da totalidade dos recursos próprios, nesse período, foram utilizados para financiar as aplicações em ativos fixos. O valor médio do índice calculado durante a década de 80 foi superior ao da década de 90 , que antecedeu o período de estabilidade. Mas, de 1994 a 2000 esse índice foi ainda menor.

Tabela 5. Índices médios da Imobilização dos Recursos Próprios (IRP) das cooperativas de café de Minas Gerais.

\begin{tabular}{lcccccrrr}
\hline Anos & Coavap & Minasul & Coparaíso & Cooxupé & Cafepoços & Coocafé & Carpec & Média \\
\hline 1980 a 1989 & - & - & 0,51 & 0,89 & 0,57 & 0,66 & 0,69 & 0,66 \\
1990 a 1999 & 0,71 & 0,43 & 0,83 & 0,76 & 0,98 & 0,52 & 0,62 & 0,69 \\
1994 a 2000 & 0,63 & 0,43 & 0,71 & 0,66 & 0,98 & 0,26 & 0,68 & 0,62 \\
\hline
\end{tabular}

Fonte: Dados da pesquisa

Gimenes (1999), ao analisar o comportamento do IRP das cooperativas do estado do Paraná, mostrou que $50 \%$ das cooperativas situaram-se em $0,94,20 \%$ delas apresentaram um grau de IRP superior a 1,25 e 10\% apresentaram um IRP superior a 2,62

A figura 4 mostra o comportamento médio desse índice das cooperativas da amostra durante os anos de 1980 a 2000. Percebe-se também que os anos de 1980 apresentaram índices superiores, mas, a partir de 1994, esse índice apresentou uma tendência de queda. Nos primeiros anos da década de 80 esse índice apresentou-se, em média, em torno de 0,60, sendo que a partir de meados dessa década até o ano de 1991, apresentou uma tendência crescente, em patamares superiores, atingindo o pico $(1,04)$ neste ano mas, a partir de 1994, esse índice apresentou-se de forma bastante oscilante . 
Pode-se dizer que o pico desse índice no ano de 1991 provavelmente estaria relacionado com reduções do crédito para custeio do café em Minas Gerais e do preço do café (apêndice 1 e 2), neste ano, a taxa de câmbio sobrevalorizada foi prejudicial às exportações. Esses três fatores contribuiram para as cooperativas apresentarem uma diminuição nas sobras, afetando indiretamente a conta PL.

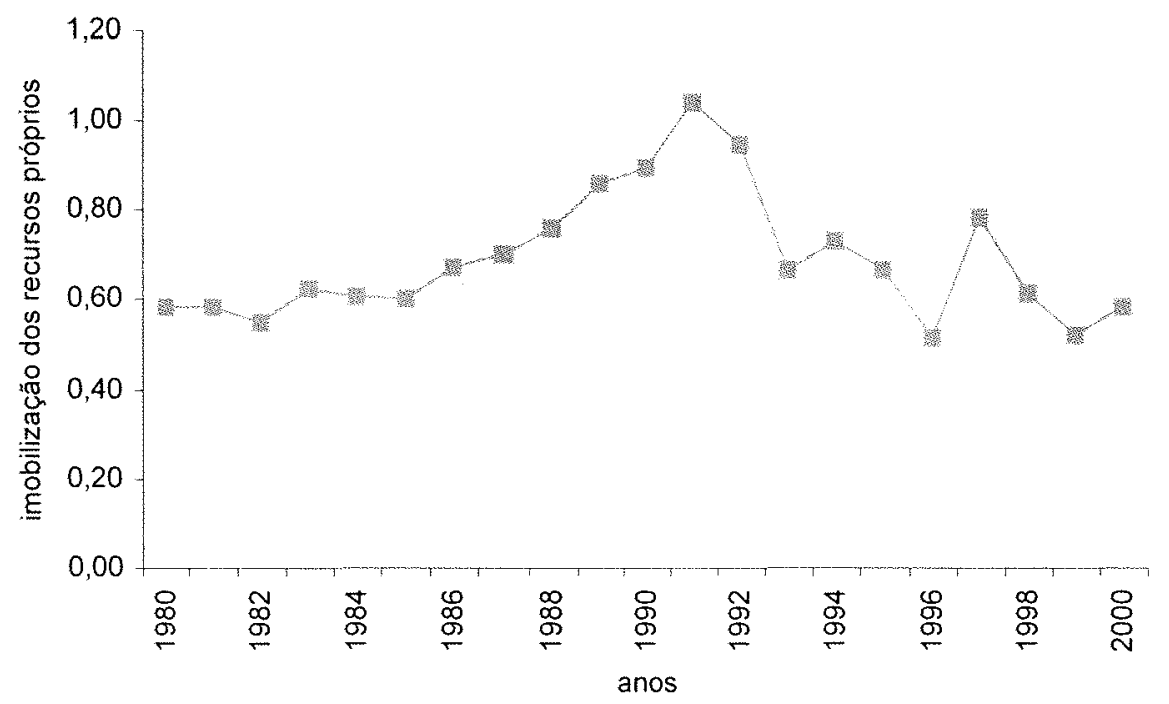

Figura 4 - Imobilização dos Recursos Próprios média das cooperativas de café do estado de Minas Gerais no período de 1980 a 2000.

\subsubsection{Independência Financeira (IF)}

A independência financeira de uma empresa demonstra sua capacidade de solver ou autofinanciar dívidas contraídas; serve para indicar qual a participação dos seus recursos próprios (patrimônio líquido) no ativo total da empresa.

$$
I F=\frac{P L}{A T} \times 100
$$


Quanto menor se apresentar esse índice, mais dependente de Capital de Terceiros a cooperativa se encontrará. Através da tabela 6, percebe-se que as cooperativas em estudo, durante a década de 1980, tinham uma menor participação de capital de terceiros $(I F=39 \%)$ em relação à década de $90(I F=30 \%)$, apresentando, a partir de 1994, uma queda da participação de capital de terceiros (33\%), isto é, um aumento na sua independência financeira.

Tabela 6. Índices médios da Independência Financeira $(I F)$ em \% das cooperativas de café de Minas Gerais.

\begin{tabular}{lcccccccc}
\hline Anos & Coavap & Minasul & Coparaíso & Cooxupé & Cafepoços & Coocafé & Carpec & Média \\
\hline 1980 a 1989 & - & - & 35,64 & 29,59 & 32,71 & 41,73 & 56,56 & 39,25 \\
1990 a 1999 & 35,26 & 55,17 & 21,83 & 30,95 & 70,01 & $-15,28$ & 50,51 & 30,46 \\
1994 a 2000 & 26,81 & 55,17 & 25,82 & 30,59 & 68,06 & $-25,67$ & 52,97 & 33,39 \\
\hline
\end{tabular}

Fonte: Dados da pesquisa

Através da figura 5, pode-se perceber o comportamento desse índice ao longo das duas décadas analisadas. Nos quatro primeiros anos da década de 1980, ocorreu um crescimento contínuo da $I F$, mas, de 1985 a 1994, ocorreu uma expressiva oscilação, com tendência decrescente. De 1994 a 1997, nos primeiros anos do Plano Real, esse índice apresentou um comportamento crescente. Mas, a partir de então, apresentou taxas decrescentes, com uma tendência de aumentado da dependência de capital externo. 


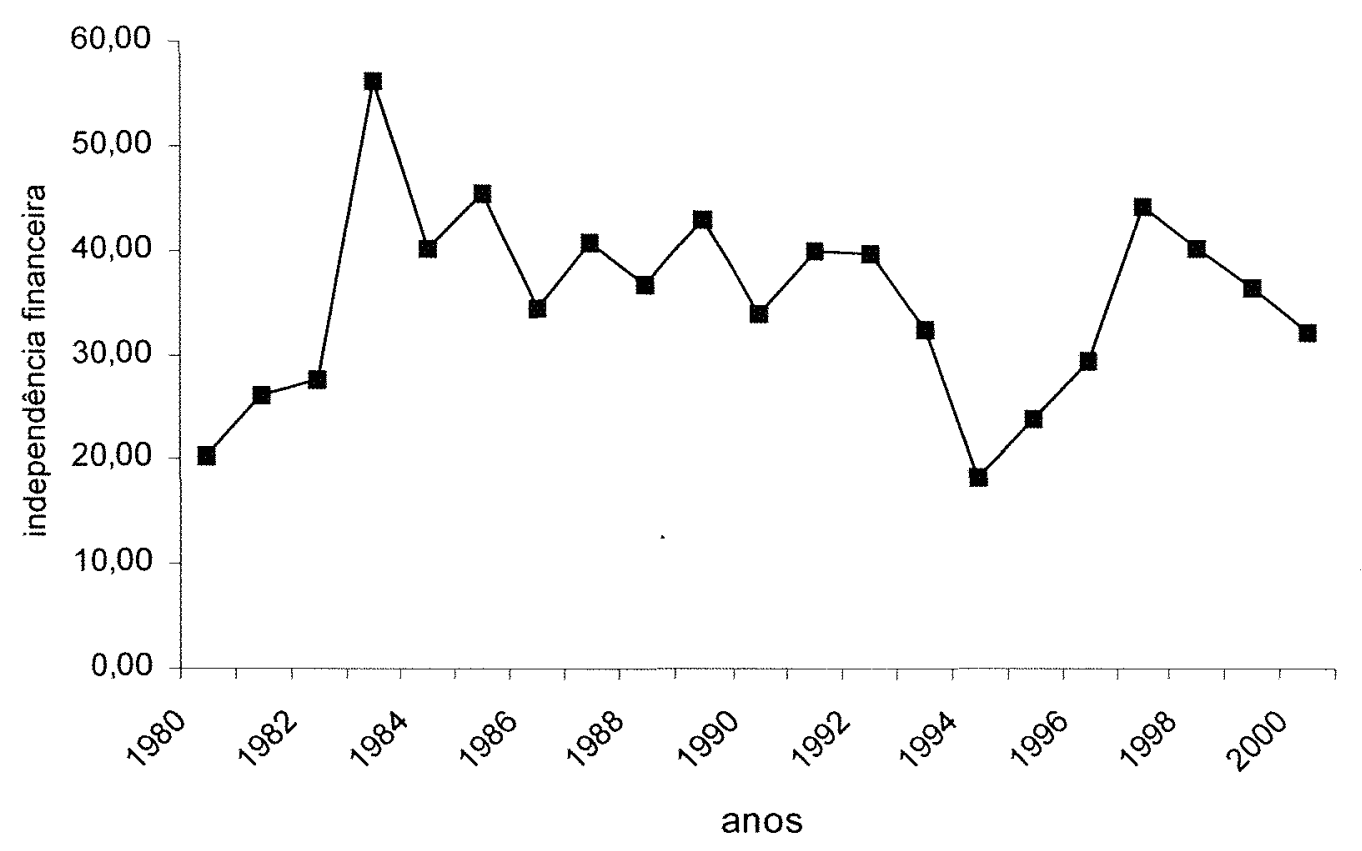

Figura 5 - Independência Financeira média das cooperativas de café do estado de Minas Gerais no período de 1980 a 2000.

Menegário (2001), ao caracterizar os indicadores socioeconômicos na situação financeira das cooperativas agropecuárias do Paraná, particularmente na previsão de inadimplência, mostrou a predominância de capital de terceiros em evolução crescente do período de 1995 a 1998, mostrando a dificuldade que essas cooperativas enfrentaram no sentido de obter recursos de seus cooperados.

Os índices $L C, L S, M G, I R P$ e $I F$ são considerados índices de liquidez e, foram usados para avaliar a eficiência financeira das cooperativas durante o período de 1980 a 2000. 


\subsubsection{Giro do Ativo $(G A)$}

O giro do ativo faz parte de um grupo de indicadores que apontam a capacidade operacional das cooperativas, medindo quantas vezes o faturamento da empresa, ou seja, as vendas de mercadorias e serviços superam o ativo total da mesma (indicador de rentabilidade). Sua fórmula é expressa da seguinte maneira:

$$
G A=\frac{V D}{A T}
$$

onde:

$G A=$ giro do ativo;

$V D=$ vendas;

$A T=$ ativo total

Esse índice representa o número de vezes que os ativos totais se renovam durante o período analisado. É considerado um bom indicador da produtividade dos ativos alcançada pelos gestores da organização, o qual mede a capacidade da cooperativa em gerar um maior faturamento com o mesmo volume e estrutura de ativos. São desejáveis índices de maior magnitude. A tabela 7 ilustra o comportamento médio do índice giro do ativo das cooperativas analisadas.

Percebe-se que, na década de 80 , o valor médio do $G A$ das cooperativas em análise foi inferior ao valor da década de $90(2,44)$, mas, no período considerado de estabilidade (1994-2000), esse índice apresentou um valor médio inferior $(2,35) \mathrm{em}$ relação ao da década de 90 . 
Tabela 7. Índices médios do Giro do Ativo $(G A)$ das cooperativas de café de Minas Gerais.

\begin{tabular}{lcccccccc}
\hline Anos & Cooxupé & Cooparaíso & Minasul & Coocafé & Cafépoços & Carpec & Coavap & Média \\
\hline 1980 a 1989 & 0,78 & 3,12 & - & 0,27 & 0,81 & 0,98 & - & 1,19 \\
1990 a 1999 & 0,27 & 0,95 & 5,78 & 0,46 & 0,78 & 4,27 & 4,55 & 2,44 \\
1994 a 2000 & 0,27 & 1,12 & 4,13 & 0,53 & 1,03 & 5,44 & 3,93 & 2,35 \\
\hline
\end{tabular}

Fonte: Dados da pesquisa

Gimenes (1999), ao analisar o comportamento desse índice nas cooperativas do estado do Paraná mostrou que em $50 \%$ das cooperativas analisadas ocorreu um $G A$ de 1,61 (na mediana), ou seja, para 50\% das cooperativas analisadas houve uma renovação dos seus ativos em 1,61 vez ao ano. Para 20\% das cooperativas, o $G A$ ficou abaixo de 0,86 e para $10 \%$ das cooperativas, o valor do índice foi superior a 4,79 .

Através da figura 6, percebe-se que durante toda a década de 80 , o $G A$ apresentou tendência de queda, oscilando entre 0,5 e 2,8, sendo que o ano de 1980 se destaca por apresentar o maior indicador de rentabilidade $(2,8)$. Comparando as duas décadas analisadas, pode-se dizer que esse indicador de desempenho da cooperativa apresentou os maiores índices na década de 90 - em relação à década de 80 . Durante o período de 1994 a 1997, esse índice cresceu, mas a partir de 1997 declinou. Tudo indica que esse declínio está relacionado com a sobrevalorização do câmbio verificada nos de 1995 a 2000, com exceção para 1999 e, com o cenário de preços decrescentes nos últimos anos da década de 90 (apêndice 02). Tais condições afetam diretamente as vendas das cooperativas desestimulando novos investimentos e a adequada manutenção das lavouras pelos cafeicultores.

Mas, apesar da tendência decrescente desse índice após o ano de 1997, durante o período considerado de estabilidade, as cooperativas obtiveram os maiores patamares do mesmo (apêndice 3). Pode-se dizer que esse comportamento está relacionado diretamente com o preço da saca de café, visto que durante esses anos houve aumentos expressivos do café em relação aos anos anteriores. O pico ocorrido em 1997 
conforme figura 6, corresponde ao maior valor da saca de café ( US\$184,28) ocorrido nesse período (apêndice 2).

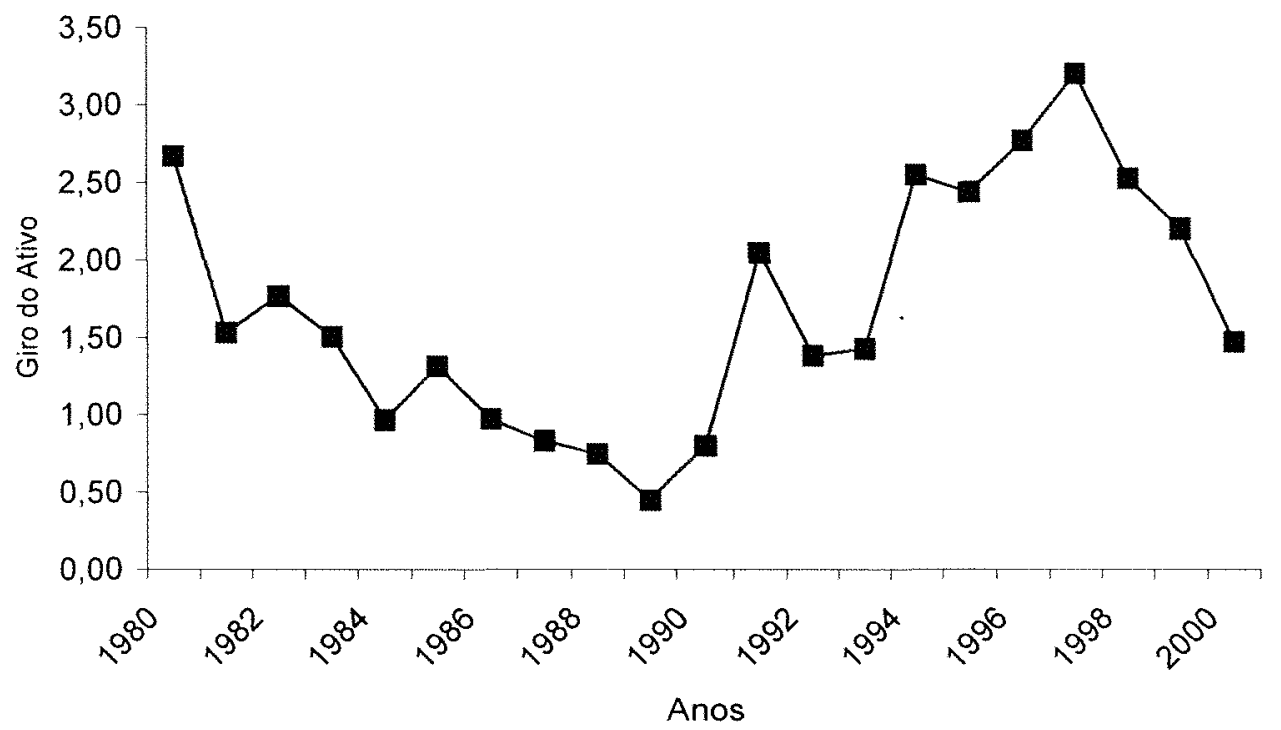

Figura 6 - Giro médio do ativo das cooperativas de café do estado de Minas Gerais no período de 1980 a 2000 .

\subsubsection{Retorno sobre Investimento $(R I)$}

O retorno sobre o investimento $(\mathrm{RI})$ juntamente com a margem de garantia e rentabilidade do patrimônio líquido fazem parte de um grupo de indicadores que avalia os resultados da empresa obtidos durante determinado período.

Sua fórmula:

$$
R I=\frac{S L p}{A T} \times 100
$$

onde: 
$R I=$ retorno sobre investimento;

$S L p=$ sobras líquidas do período;

$A T=$ ativo total.

O Retorno sobre o Investimento de uma cooperativa mede a capacidade da mesma em obter sobras em relação ao total de ativos que possui. Sua interpretação é de quanto maior, melhor. Isto é, esse índice é uma medida da capacidade da empresa em gerar sobras e, assim, poder capitalizar-se. A tabela 8 mostra que as cooperativas tiveram uma acentuada redução média desse índice na década de 1990 (2,31), em relação à década de $1980(9,95)$, isto é, reduziram drasticamente seu poder de capitalização. Mas, no período de 1994 a 2000, houve um aumento do patamar médio desse índice $(3,65)$.

Tabela 8. Índices médios do Retorno sobre Investimento $(R I)$ em \% das cooperativas de café de Minas Gerais.

\begin{tabular}{lcccccccc}
\hline Anos & Coavap & Minasul & Coparaíso & Cooxupé & Cafépoços & Coocafé & Carpec & Média \\
\hline 1980 a 1989 & - & - & 6,07 & 6,60 & 4,57 & 8,84 & 23,69 & 9,95 \\
1990 a 1999 & 7,81 & 3,73 & $-0,37$ & 3,66 & $-2,25$ & $-2,75$ & 6,32 & 2,31 \\
1994 a 2000 & 14,33 & 2,66 & $-0,03$ & 4,85 & $-0,60$ & 3,58 & 0,72 & 3,65 \\
\hline
\end{tabular}

Fonte: Dados da pesquisa

Gimenes (1999) mostrou que, para 50\% das cooperativas paranaenses, o $R I$ (usando o ativo líquido no cálculo) estabeleceu-se em 5,01\% ao ano. Para $40 \%$ das cooperativas, o índice situou-se abaixo de 3,95\% e, para apenas para $20 \%$ das cooperativas, o $R I$ foi igual ou superior a $12,24 \%$ ao ano. 


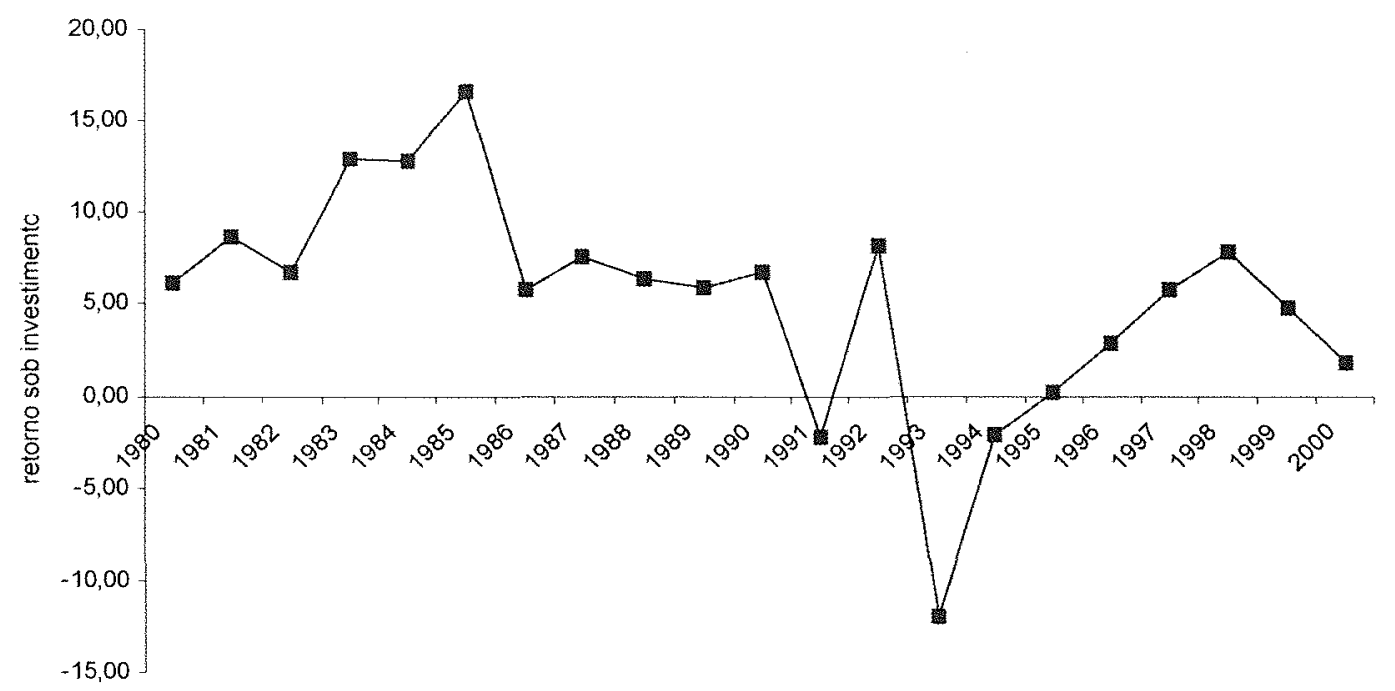

anos

Figura 7 - Retorno sobre Investimento médio das cooperativas de café do estado de Minas Gerais no período de 1980 a 2000.

Através da figura 7, pode-se perceber o comportamento do valor médio do $R I$ ao longo do período analisado. Durante a década de 1980, as cooperativas tiveram melhores resultados desse índice comparado com os resultados da década de 1990, tendo uma ligeira recuperação durante os anos de 1995 a 1998. Porem, apresentando a partir daí, uma tendência decrescente. Nos anos de 1991, 1993 e 1994 o RI médio apresentouse negativo. Isso deveu-se ao fato de as cooperativas Cooparaíso, Cafépoços e Coocafé terem apresentado sobras negativas nesses anos, levando esse índice a apresentarem valores negativos.

O comportamento crescente desse índice de 1980 a 1985 coincide com períodos favoráveis à cafeicultura, tanto em preços quanto em volume de crédito e taxas de juros altamente subsidiadas. Já o período de 1986 a 1993, em que o RI mostrou-se de forma mais oscilante, foi marcado por momentos de crises, com elevados níveis de inflação e preços de café deprimidos. 
Dentro de uma análise pontual, observando os anos correspondentes a picos na figura 7 , nota-se que no ano de 1985 , em que o RI apresentou-se num patamar mais elevado, o preço da saca de café subiu 60\% (apêndice 2). No ano de 1993, onde esse índice apresentou-se no menor patamar $(-11,97)$, mostrando a ocorrência de sobras negativas em algumas das cooperativas em estudo (tabela 8), corresponde ao ano em que ocorrera uma apreciação do câmbio e diminuição de $75 \%$ do volume de crédito para custeio do café em Minas Gerais. Pode-se dizer que esse cenário levou as cooperativas a apresentarem sobras negativas nesse ano.

\subsubsection{Rentabilidade do Patrimônio Líquido (RPL)}

Esse indicador tem a função de apontar qual a capacidade da empresa em remunerar seu patrimônio líquido (capital próprio + fundos e reservas). É importante para mensurar o custo de oportunidade da capitalização na cooperativa. Sua fórmula:

$$
R P L=\frac{S L p}{P L} \times 100
$$

onde:

$R P L=$ rentabilidade do patrimônio líquido;

$S L p=$ sobras líquidas do período;

$P L=$ patrimônio líquido.

O papel do índice de rentabilidade do patrimônio líquido é mostrar qual a taxa de rendimento do capital próprio, ou seja, a remuneração dos proprietários do capital. Essa taxa pode ser comparada com a de outros rendimentos alternativos no mercado, como caderneta de poupança, CDBs, Letras de câmbio, ações etc. Com isso, pode-se avaliar se a empresa oferece rentabilidade superior ou inferior a essas alternativas. ao interpretação do índice $R P L$ é no sentido de quanto maior, melhor. A 
tabela 9 ilustra o comportamento médio desse índice ao longo das décadas de 1980 e 1990 das cooperativas selecionadas na amostra.

Tabela 9. Índices médios da Rentabilidade do Patrimônio Líquido $(R P L)$ das cooperativas de café de Minas Gerais.

\begin{tabular}{lcccccccc}
\hline Anos & Coavap & Minasul & Coparaíso & Cooxupé & Cafepoços & Coocafé & Carpec & Média \\
\hline 1980 a 1989 & - & - & 0,19 & 0,22 & 0,11 & 0,19 & 0,45 & 0,23 \\
1990 a 1999 & 0,32 & 0,06 & $-0,02$ & 0,12 & $-0,03$ & 0,78 & 0,18 & 0,20 \\
1994 a 2000 & 0,44 & 0,06 & 0,00 & 0,16 & $-0,01$ & 0,97 & 0,04 & 0,24 \\
\hline
\end{tabular}

Fonte: Dados da pesquisa

Esses dados evidenciam que essas cooperativas, com exceção da Coocafé, apresentaram melhores índices médios durante a década de $80(0,23)$ em relação à de 90 $(0,20)$, sendo que a Cooparaíso e a Cafépoços apresentaram valores médios negativos durante os anos de 1990, indicando prejuízos ocorridos nos exercícios fiscais analisados.

Mas, a partir de 1994, houve uma melhora desse índice $(0,24)$ - dentro do período analisado. Esse resultado mostrou uma taxa de rendimento de capital próprio muito baixa em relação ao resultado encontrado para as cooperativas do estado do Paraná.

Gimenes (1999), ao analisar o comportamento do $R P L$ das cooperativas do estado do Paraná, mostrou que em 50\% delas o índice foi igual a 1,23\%, ou seja, a sobra líquida produzida ao final do exercício, representando o retorno do capital próprio do cooperado, foi equivalente a $1,23 \%$ do valor investido. Em $30 \%$ das cooperativas o índice apresentou um valor negativo. Para 70\%, a RPL ficou abaixo de 2,96\%, para 20\% delas, a taxa apresentou um valor igual ou superior a $8,68 \%$ e $10 \%$ das cooperativas chegaram a ter um $R P L$ superior a $14,32 \%$ ao ano. 
Segundo Pérez (1999), a rentabilidade média dos recursos próprios proporcionada pelas sociedades cooperativas espanholas $(7,4 \%)$ foi superior à das sociedades anônimas (2,4\%) no período de 1988 a 1996.

A figura 8 mostra o comportamento médio desse índice das cooperativas da amostra, nos anos de 1980 a 2000 . O valor médio desse índice de 1980 a 1985 variou em torno de 30\%, sendo que em 1986 a média caiu para $-2,0 \%$. De 1987 a 1990, há uma recuperação, passando a ficar em torno de $20 \%$; em 1991, volta a cair para $-9,0 \%$; de 1992 a 1996, ficou em torno de $20 \%$ e em 1997, a média desse índice chegou a $60 \%$, declinando a partir de então.

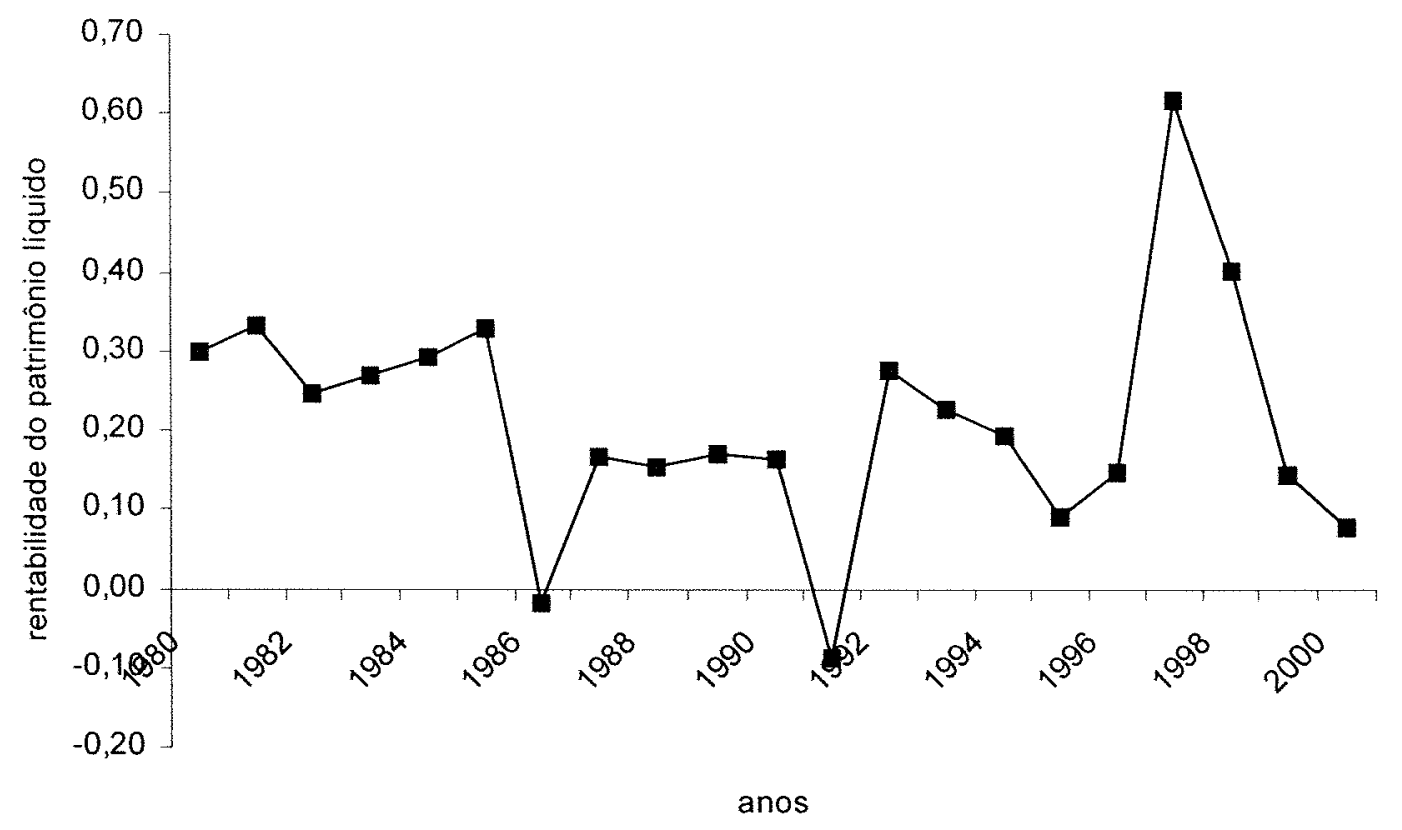

Figura 8 - Rentabilidade do Patrimônio Líquido médio das cooperativas de café do estado de Minas Gerais no período de 1980 a 2000. 
Pode-se dizer que o ano de 1992, por ter apresentado o menor preço da saca de café entre os anos analisados, aliado a uma queda de quase $50 \%$ do crédito para o café em Minas Gerais (apêndices 1e 2), levaram as cooperativas Cooparaíso e Cafepoços, nesse ano, a incorrer em sobras negativas. Isso condiz com o valor negativo do índice RPL apresentado na figura 8. Por outro lado, o pico ocorrido no ano de 1997 deveu-se ao aumento do preço da saca de café e do crédito para custeio desse produto nesse ano.

Ferreira (1999), ao analisar o desempenho econômico das cooperativas de café e leite da região sul do estado de Minas, através do levantamento de índices-padrão, no período de 1994 a 1997, mostrou que as de café apresentaram menores índices de margem bruta, retorno sobre investimento e retorno sobre o patrimônio líquido, em relação às cooperativas de leite.

Padoveze (1996) estabeleceu um parâmetro de que a rentabilidade da empresa deve ser, em situação conjuntural normal, entre $12 \%$ e aproximadamente $18 \%$ ao ano, isto é, dependendo do momento conjuntural e da situação que a empresa está passando. Segundo o autor, é comum a empresa abdicar de parte da margem em situações de ociosidade e baixa demanda. Rentabilidade do patrimônio líquido abaixo de $12 \%$ ao ano pode ser considerada fraca e acima de $18 \%$ considerada excepcional.

\subsubsection{Endividamento de Longo Prazo (ELP)}

Os indicadores financeiros que dizem respeito ao endividamento da empresa englobam o endividamento total e o de longo prazo. $\mathrm{O}$ indicador de endividamento de longo prazo serve para mostrar o quanto do endividamento da empresa é originário de fontes que fornecem recursos de capital de longo prazo. O cálculo desse indicador é expresso na fórmula a seguir:

$$
E L P=\frac{E X L P}{A T} \times 100
$$

onde: 
$E L P=$ endividamento de longo prazo;

$A T=$ ativo total;

$E X L P=$ exigível de longo prazo.

O grau de endividamento de longo prazo indica o volume de recursos de longo prazo de terceiros aplicados nas cooperativas para o financiamento dos investimentos totais. A diferença entre o endividamento de curto e longo prazo está no seu período de realização, pois o de curto prazo se realiza em tempo inferior a 360 dias, e o de longo prazo, superior a este. De maneira geral, o grau de endividamento de curto prazo é maior que o de longo prazo, refletindo uma utilização de recursos de terceiros de curto prazo. A tabela 10 mostra que das 7 cooperativas analisadas, somente 5 delas apresentaram um endividamento considerado de longo prazo. Percebe-se, também, que durante a década de 90 , notadamente no período considerado de estabilidade, a média do ELP das cooperativas em análises foi superior $(24,30 \%)$ em relação aos anos de 1980 $(2,08 \%)$.

Tabela 10. Índices médios do Endividamento de Longo Prazo em \% (ELP) das cooperativas de café de Minas Gerais.

\begin{tabular}{lcccccccc}
\hline Anos & Coavap & Minasul & Coparaíso & Cooxupé & Cafepoços & Coocafé & Carpec & Média \\
\hline 1980 a 1989 & - & - & 2,47 & 4,87 & 0,78 & 0,22 & - & 2,08 \\
1990 a 1999 & - & 14,43 & 23,68 & 18,89 & 10,77 & 33,16 & - & 20,19 \\
1994 a 2000 & - & 14,43 & 27,12 & 22,63 & 13,27 & 44,07 & - & 24,30 \\
\hline
\end{tabular}

Fonte: Dados da pesquisa

Através da figura 9, pode-se notar o comportamento crescente do ELP dessas cooperativas durante as duas décadas analisadas, apresentando uma tendência declinante a partir de 1996. 


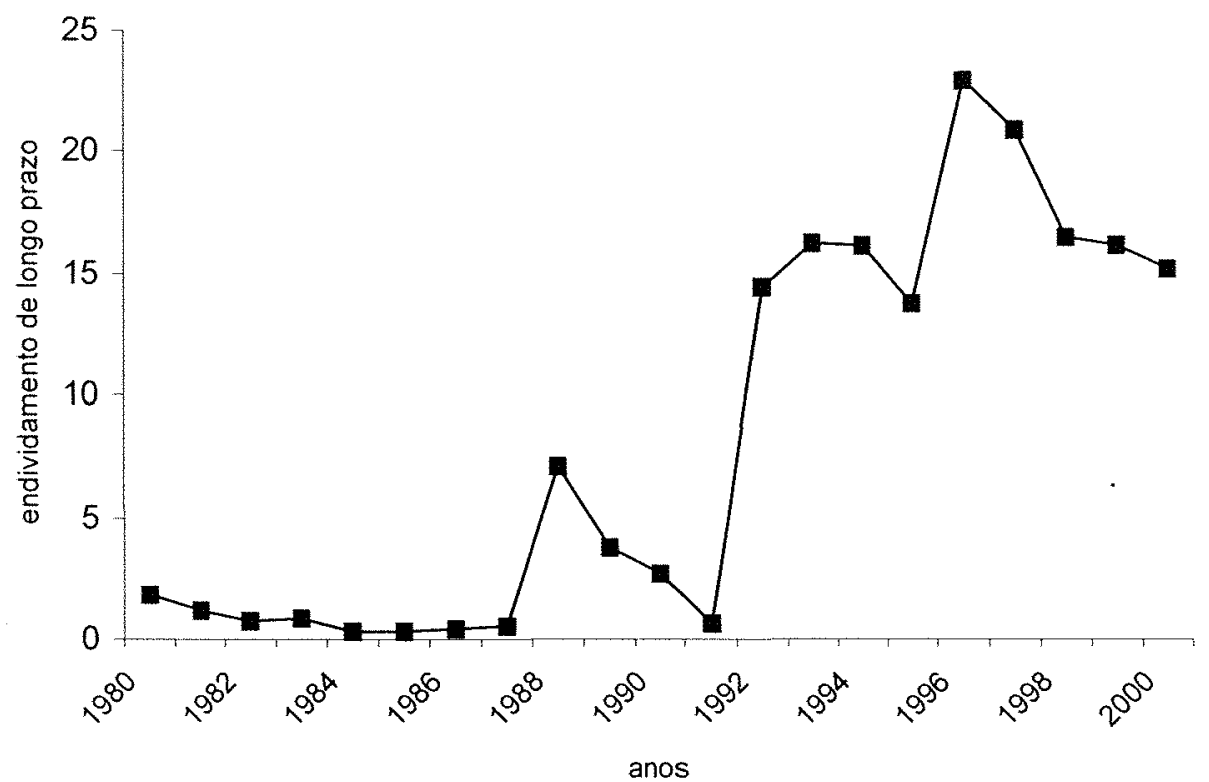

Figura 9 - Endividamento de longo prazo médio das cooperativas de café do estado de Minas Gerais no período de 1980 a 2000.

O índice ELP apresentou tendência de crescimento a partir de 1987. Nesse período iniciou-se um processo de apreciação de câmbio e de aviltamento dos preços internacionais do café. Para a agricultura de modo geral houve grandes prejuízos através da política cambial e de importações de alimentos visando controle de preços e contenção das taxas de inflação. Deve-se lembrar que a agricultura, de modo geral, endividou-se nesse mesmo período.

Outro fator que contribuiu para o crescimento do ELP são a instabilidade macroeconômica imposta pelos planos econômicos. A partir de 1991 verificou-se forte crescimento do ELP. Pode-se dizer que, nos anos do Plano Collor I, a forte crise de liquidez, o menor preço da saca de café (US\$53,09/sc) em 1992 e a continuidade da apreciação do câmbio, (apêndice 2) justificam o comportamento desse índice aqui analisado. 
No ano de 1994, com a geada no mês de junho, inicia-se um período de recuperação dos preços de café. Em toda a série estudada, os anos de 1994 e 1993 são respectivamente o $3^{\underline{0}}$ e $4^{\underline{0}}$ maiores preços verificados para o café. Entre esses dois anos, verificou-se uma diminuição do ELP. Provavelmente produtores e cooperativas puderam saldar dívidas e receberem estímulos via preços, para iniciarem novo ciclo de investimentos e de expansão do agronegócio do café. Isso ajudaria a entender os patamares mais elevados do ELP para os 5 últimos anos do período analisado.

A implantação do RECOOP juntamente com um cenário de melhores preços do café contribuíram para a tendência declinante do índice ELP das cooperativas em estudo.

Esse comportamento do ELP aqui verificado condiz com a situação de endividamento das cooperativas agropecuárias brasileiras, contraídas no sistema financeiro. Com raras exceções, as cooperativas agropecuárias encontram-se em situação de elevado endividamento, notadamente em operações de longo prazo realizadas no sistema financeiro (Menegário, 2000).

\subsubsection{Endividamento Total $(E T)$}

O endividamento total mensura a utilização dos recursos, como empréstimos e financiamentos nos investimentos internos da empresa, no curto e longo prazo. Sua fórmula:

$$
E T=\frac{P C+E X L P}{A T} \times 100
$$

onde:

$E T=$ endividamento total;

$P C=$ passivo circulante;

$A T=$ ativo total;

$E X L P=$ empréstimo de longo prazo. 
A rentabilidade e o endividamento são variáveis mais freqüentemente utilizadas por suas capacidades de previsão obtidas através dos modelos de previsão de insolvências nas sociedades cooperativas (Gimenes \& Opaso, 2001).

O grau de endividamento total indica o volume utilizado de recursos externos para o financiamento dos investimentos totais (ativo total), ou seja, mede o montante de dinheiro de terceiros que está sendo empregado para gerar sobras. É um indicador de risco ou de dependência a terceiros, fazendo análise exclusivamente do ponto de vista financeiro, ou seja, do risco de insolvência das cooperativas.

Através da tabela 11, pode-se perceber que, durante a década de 80 , as cooperativas em análise tiveram um ET médio menor $(60,62 \%)$ em relação à década de $1990(62,77 \%)$. Portanto, pode-se perceber que, durante o período de estabilidade, elas tiveram um aumento na participação de capital de terceiros na geração de suas sobras $(E T=64,09 \%)$, mostrando que as dificuldades e as diferenças econômicas financeiras dessas cooperativas tornaram-se mais evidentes após o Plano Real.

Tabela 11. Índices médios do Endividamento Total em \% $(E T)$ das cooperativas de café de Minas Gerais.

\begin{tabular}{lcccccccc}
\hline Anos & Coavap & Minasul & Coparaíso & Cooxupé & Cafépoços & Coocafé & Carpec & Média \\
\hline 1980 a 1989 & - & - & 88,35 & 66,91 & 66,91 & 49,18 & 31,78 & 60,62 \\
1990 a 1999 & 60,35 & 44,83 & 78,15 & 69,05 & 29,99 & 111,48 & 45,54 & 62,77 \\
1994 a 2000 & 66,91 & 44,83 & 74,16 & 69,41 & 31,93 & 125,04 & 36,36 & 64,09 \\
\hline
\end{tabular}

Fonte: Dados da pesquisa

Gimenes (1999), ao analisar o grau de endividamento das cooperativas do estado do Paraná, revelou que há uma predominância de recursos de terceiros em relação aos recursos próprios. Em alguns casos esse índice alcançou 361,50\%. Quanto à composição desse endividamento, constatou que $72,50 \%$ dos recursos de terceiros são obrigações de curto prazo, alcançando $92,50 \%$ em algumas cooperativas. 
Ferreira (1999), ao analisar a situação financeira, econômica e político-social através do levantamento de índices-padrão das cooperativas agropecuárias de leite e café da região sul do estado de Minas Gerais, no período de 1994 a 1997, mostrou que, em termos de liquidez, as cooperativas não tiveram dificuldades a curto prazo. Mas, na análise por atividade, as cooperativas de café apresentaram menores índices de liquidez e maior endividamento.

A tendência declinante desse indice de 1981 a 1985, como mostra a figura 10 , indica uma situação de recuperação dessas cooperativas, no sentido de ter uma menor participação de capital de terceiros na geração de sobras.

Pode-se dizer que o comportamento oscilante desse índice observado durante todo o período está ligado à redução do crédito agrícola na economia brasileira, retratando também a busca por melhor desempenho econômico-financeiro baseado no endividamento, o que acabou gerando maiores dificuldades financeiras para o setor. 


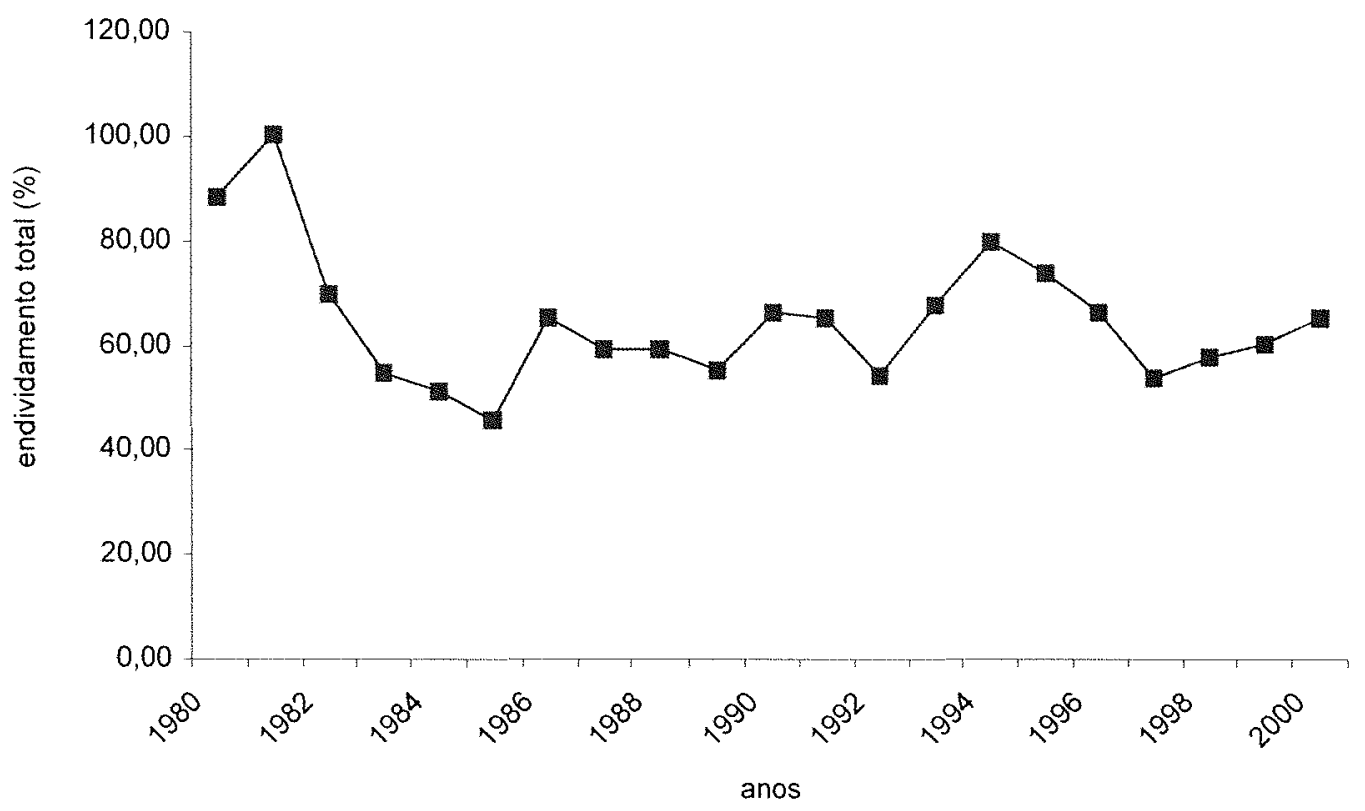

Figura 10 - Endividamento Total médio das cooperativas de café do estado de Minas Gerais no período de 1980 a 2000.

Pode-se dizer, em geral, que as oscilações dos indicadores financeiros aqui analisados, provavelmente, estão ligadas a possíveis problemas com custos operacionais, financeiros ou capacidade competitiva. Entretanto, podem também estar relacionadas com a política de crédito e com o mercado, isto é, com dois problemas "básicos" de origem governamental: a insuficiência de crédito rural oficial e a política cambial irrealista $^{7}$. A isso somam-se os problemas advindos dos congelamentos praticados durante o período que antecedeu a estabilização dos preços no mercado interno. Quando houve restrições de crédito agrícola por parte do governo ou o preço do café estava em baixa, as cooperativas acabavam por financiar o cooperado.

\footnotetext{
7 Para Nogueira \& Oliveira (1997), a política cambial dos últimos anos foi severa com o setor agrícola. A valorização da moeda nacional desde 1990, por um lado, aumentou o preço das exportações e, por outro, reduziu o valor dos produtos importados, diminuindo os preços recebidos pelos produtores, e, por conseguinte, a receita do setor. Silva \& Carvalho (1995) analisaram a evolução dos preços das principais "commodities" brasileiras, no período 1990-94, e concluíram que os produtores não se apropriaram desse aumento devido à defasagem cambial.
} 


\section{MODELO ANALÍTICO}

Para verificar o impacto de variáveis na probabilidade de ocorrência de sobras nas cooperativas, foi especificado o modelo Logit, em que a variável dependente - sobras e perdas das cooperativas em estudo - admite valores discretos, um e zero respectivamente - variável binária. Assim, a probabilidade de ocorrência de cada resposta binária é decorrente de um conjunto de variáveis macroeconômicas e de indicadores financeiros das cooperativas em estudo.

A técnica de análise Logit aplica-se para a obtenção da probabilidade de que uma observação pertença a um conjunto determinado, em função do comportamento das variáveis independentes. Nesse caso, as variáveis independentes são as macroeconômicas e os índices financeiros das cooperativas de café do estado de Minas Gerais em estudo. Gimenes \& Opaso (2001), ao descrever e analisar modelos de previsão de insolvência das cooperativas agropecuárias paranaenses, mostraram que o modelo Logit obteve um nível de acerto de 96,16\% contra 92,3\% do modelo discriminante. No que se refere à precisão na classificação de empresas como solventes ou insolventes, estudos empíricos têm demostrado que os resultados encontrados tendem a ser mais favoráveis para os modelos construídos com base no modelo Logit. 


\subsection{Descrição das variáveis}

$\mathrm{Na}$ intenção de conhecer variáveis macro que influenciam o desempenho das cooperativas de café do estado de Minas Gerais, consideraram-se como variáveis dependentes, para este estudo, as sobras ou os prejuízos das cooperativas. A ocorrência de sobras nas cooperativas é função de vários fatores. Neste estudo, as variáveis consideradas importantes são definidas a seguir.

\subsubsection{Sobras}

O desempenho financeiro das cooperativas pode ser medido pela ocorrência de sobras no final de cada exercício. O destino das sobras é definido pelos associados em Assembléia Geral Ordinária, que é realizada até o mês de março de cada ano. Os cooperados podem optar por reinvestir as sobras na cooperativa, por meio de capitalização e/ou investimento, ou distribuí-las aos associados, de acordo com a movimentação de cada membro.

A ocorrência de sobras é resultado de uma série de fatores, tanto de natureza administrativa específica de cada cooperativa quanto de políticas econômicas estabelecidas no ambiente onde estão inseridas.

Essa informação é útil para a própria cooperativa, para o sistema financeiro que tem interesse em fornecer crédito a essas empresas e para o governo na implementação e reformulação de novas políticas.

\subsubsection{Valor dos Contratos do Crédito para o Café em Minas Gerais}

A institucionalização do crédito rural representa um marco para o setor agropecuário no que diz respeito ao apoio formalizado do governo para o seu desenvolvimento. Foi tido como principal instrumento de política econômica utilizada para viabilizar o desenvolvimento da agricultura brasileira e sua conseqüente modernização, de forma a coadjuvar e acompanhar o desenvolvimento do Brasil (Carvalho, 2000). 
Os valores em reais de dezembro de 2000 do crédito rural aplicados foram bastante significativos, apesar da queda ocorrida nos anos 90 como mostra a tabela 12 .

Tabela 12. Valor dos contratos do crédito rural para o café no estado de Minas Gerais de 1980 a 2000; valores em reais de dezembro/2000.

\begin{tabular}{|c|c|c|c|c|}
\hline Anos & Custeio & Pré-comercialização & Investimento & Total \\
\hline 1980 & $817.417 .737,58$ & $57.952 .970,35$ & $48.737 .330,52$ & $924.108 .038,45$ \\
\hline 1981 & $387.012 .101,22$ & $63.298 .268,68$ & $19.945 .805,64$ & $470.256 .175,55$ \\
\hline 1982 & $540.446 .984,86$ & $52.407 .855,94$ & $622.007,05$ & $593.476 .847,85$ \\
\hline 1983 & $359.733 .680,99$ & $22.579 .348,27$ & $719.846,74$ & $383.032 .876,00$ \\
\hline 1984 & $247.914 .866,87$ & $5.799 .036,72$ & $928.321,83$ & $254.642 .225,42$ \\
\hline 1985 & $46.744 .144,76$ & $131.859,22$ & $86.015,96$ & $46.962 .019,95$ \\
\hline 1986 & $283.068 .406,88$ & $6.003 .951,29$ & - & $289.072 .358,18$ \\
\hline 1987 & $485.462 .908,17$ & $3.891 .892,45$ & $3.667 .604,00$ & $493.022 .404,62$ \\
\hline 1988 & $163.010 .218,89$ & - & - & $163.010 .218,89$ \\
\hline 1989 & $281.884 .623,99$ & $4.818 .146,86$ & $4.088 .284,16$ & $290.791 .055,01$ \\
\hline 1990 & $220.901 .733,20$ & $23.238 .512,63$ & $1.010 .525,06$ & $245.150 .770,90$ \\
\hline 1991 & $135.752 .630,68$ & - & $1.088 .875,36$ & $136.841 .506,05$ \\
\hline 1992 & $73.388 .235,85$ & $994.942,80$ & $751.334,98$ & $75.134 .513,64$ \\
\hline 1993 & $17.809 .982,31$ & $876.080,53$ & $170.684,98$ & $18.856 .747,82$ \\
\hline 1994 & $38.871 .504,32$ & $7.191 .729,12$ & $737.457,95$ & $46.800 .691,40$ \\
\hline 1995 & $23.184 .069,86$ & $1.777 .342,08$ & $38.784 .737,98$ & $63.746 .149,92$ \\
\hline 1996 & $8.427 .785,55$ & $1.009 .585,12$ & $34.911 .559,07$ & $44.348 .929,73$ \\
\hline 1997 & $269.051 .507,01$ & $3.560 .673,23$ & $32.352 .082,94$ & $304.964 .263,18$ \\
\hline 1998 & $183.368 .040,72$ & $7.896 .938,57$ & $31.139 .559,34$ & $222.404 .538,62$ \\
\hline 1999 & $85.851 .169,31$ & $601.380,78$ & $27.968 .791,11$ & $114.421 .341,20$ \\
\hline 2000 & $148.778 .485,60$ & $10.318 .684,40$ & $23.307 .202,30$ & $182.404 .372,31$ \\
\hline
\end{tabular}

Fonte: Banco Central do Brasil (vários números)

Uma análise da evolução e distribuição do crédito rural feita por Carvalho (2000) mostrou que, a partir de 1980, os volumes de recursos disponíveis, via crédito 
rural, foram ficando cada vez mais restritivos, evidenciando, nesse período, mudanças nas regras. Essas alterações foram influenciadas pelo agravamento da crise da economia brasileira e sua relação crítica com a economia internacional, cujo reflexo foi a diminuição paulatina dos empréstimos rurais nos anos subsequentes.

\subsubsection{Taxa de Câmbio}

As taxas de câmbio nominais anuais no período de 1980 a 2000 foram obtidas da Revista Conjuntura Econômica de dezembro/2001 (número 12), expressas em R\$/US\$ e foram corrigidas com base no IGP-DI de agosto/94.

Pode-se dizer que, as taxas de câmbio e de juros são considerados canais de ligação entre a política macroeconômica e a agricultura, além de intervenções diretas via política fiscal. Nas economias abertas, a taxa de câmbio é um dos principais instrumentos básicos e sua importância decorre do fato de relacionar as transações da economia doméstica com outros países.

Variações cambiais afetam a competitividade entre os diversos setores de uma economia. Valorização da moeda nacional (apreciação do câmbio), por exemplo, reduz a competitividade dos setores exportadores e favorece as importações, e o efeito inverso é observado no caso de uma desvalorização do câmbio.

Enfim, conforme mostra Lopes (1994), após um programa de ajuste estrutural, uma recuperação econômica geralmente é liderada por setores de exportação e, nesse sentido, a taxa de câmbio desempenha um papel estratégico para o crescimento econômico. Portanto, o câmbio é um elemento estratégico para o setor agrícola, determinando sua competitividade interna, assim como dos demais setores da economia, na produção para consumo interno ou para exportação. Com um câmbio defasado, por exemplo, a agricultura acaba ficando estagnada, produz menos produtos de exportação como também os que substituem importações, prejudicando o nível de emprego e a renda doméstica. 
A economia brasileira já experimentou diversos regimes cambiais. De 1969 a fevereiro de 1990, por exemplo, o regime cambial caracterizou-se pelo monopólio do câmbio, ou seja, apenas o Banco Central podia realizar legalmente transações com divisas estrangeiras ou, eventualmente, autorizar a transação por outros agentes, sob sua fiscalização; a política cambial consistia em minidesvalorizações em intervalos aleatórios.

Segundo Zini (1995), essa política tentava evitar ataques especulativos contra a moeda doméstica e criar condições estáveis para os exportadores e importadores. Consistia em desvalorizar a taxa de câmbio nominal em intervalos freqüentes e a taxas pequenas, corrigindo o diferencial entre a inflação doméstica e a internacional. Segundo Vieira (2000), a partir de março de 1990, a taxa de câmbio passou a ser determinada de forma mais flexível. Com o Plano Real, implementado em 1994, a política cambial experimentou, por determinado período, um sistema de bandas cambiais em que eram definidos os limites inferiores e superiores para a flutuação da taxa de câmbio nominal; atualmente o câmbio é flutuante.

\subsubsection{Preço da Saca de Café}

Como toda atividade econômica, o café também está sujeito a períodos de preços favoráveis e desfavoráveis. Esses ciclos são determinados por fatores tanto endógenos quanto exógenos, como geadas, secas etc.

Para este trabalho, foi adotado o valor médio do preços do café pago ao produtor, expresso em US\$ pela saca beneficiada de $60 \mathrm{~kg}$. Eles foram obtidos nos relatórios anuais das cooperativas nos períodos de 1980 a 2000.

A liquidez corrente (LC) e o Endividamento de Longo Prazo (ELP), discutidos anteriormente no capítulo 4 , também foram considerados como variáveis do modelo analítico para a explicação de ocorrência de sobras nas cooperativas em estudo. 


\subsection{Modelo logit e resultados}

A amostra tomada para a estimação do modelo Logit foi composta por sete cooperativas agropecuárias, divididas em dois períodos: de 1980 a 2000, e de 1990 a 2000 .

O modelo Logit usa a função de distribuição acumulada logística, que e dada por:

$$
L=\left(X_{1}^{\prime} \beta\right)=\frac{1}{1+e^{-x i \beta}}
$$

Em que $L$ representa a função logística cumulativa; $X_{\mathrm{j}}$ é o vetor de variáveis independentes; $\beta$ é o vetor de parâmetros e e representa a base do logaritmo natural .

O modelo é estimado pelo Método de Máxima Verossimilhança, ou seja,

$$
L=\Pi i \frac{e^{-x i \beta}}{1+e^{-x i \beta}} \Pi j \frac{1}{1+e^{X j \beta}}
$$

Em que $i$ se refere à ocorrência de sobras nas cooperativas e $j$ à ocorrência de prejuízo nas cooperativas.

A probabilidade de ocorrer sobras nas cooperativas é calculada da seguinte forma:

$$
P_{i}=\frac{1}{1+e^{X_{i} \beta}}
$$

Em que $P_{1}$ é igual à probabilidade de ocorrer sobras; $X_{\mathrm{i}}$, são as variáveis explicativas do modelo; e $\beta$, os coeficientes das variáveis explicativas.

A probabilidade de ocorrer prejuízos nas cooperativas é calculada da seguinte maneira: 


$$
1-P_{i}=\frac{e^{-x_{i} \beta}}{1+e^{X_{i} \beta}}
$$

Sendo $1-P_{i}$ a probabilidade de ocorrer prejuízos; $X_{i}$, as variáveis explicativas do modelo; e $\beta$, os coeficientes das variáveis explicativas.

As variáveis consideradas no modelo são as seguintes: a) variável dependente: DSOBR $=$ Dummy de Sobras - variável binária -, com valor um para a ocorrência de sobras e zero para a ocorrência de prejuizo; b) variáveis independentes: $\mathrm{CCMG}=$ valor dos contratos do crédito para o café em Minas Gerais; TXCAM = Taxa de câmbio; PRSCUS = preço pago ao produtor da saca de café $(60 \mathrm{~kg}$ beneficiada em US\$); ELP = endividamento de longo prazo; e LC = liquidez corrente.

No modelo Logit, os coeficientes das variáveis explicativas não refletem o efeito marginal dessas sobre o modelo. O efeito marginal é a taxa de mudança na probabilidade de ocorrência, dada a variação de uma unidade da variável independente.

Para determinar o efeito marginal de cada variável sobre a probabilidade de ocorrência de sobras nas cooperativas, faz-se necessário o uso dos valores médios das variáveis explicativas.

O efeito marginal da variável $X_{i}$ sobre a dependente é expresso da forma descrita a seguir:

$$
\begin{aligned}
& \frac{\delta P_{i}}{\delta X_{i}}=\beta_{i} \frac{1}{1+e^{-\left(\beta_{1}+\beta_{2} X_{i}\right)}} \cdot \frac{e^{-\left(\beta_{1}+\beta_{2} X_{i}\right)}}{1+e^{-\left(\beta_{1}+\beta_{2} X_{i}\right)}} \\
& \frac{\delta P_{i}}{\delta X_{i}}=\beta_{i} \cdot P_{i} \cdot\left(1-P_{i}\right) \\
& \frac{\delta P_{i}}{\delta X_{i}}=\hat{\beta}_{i} \cdot \hat{P}_{i} \cdot\left(1-\hat{P}_{i}\right)
\end{aligned}
$$


onde:

$$
p_{i}=P\left(Y_{i}=1\right)=\frac{1}{1+e^{-\left(\beta_{3}+\beta_{2} X_{i}\right)}}
$$

Em que $\beta$ é o coeficiente da variável $X_{\mathrm{i}}, P_{\mathrm{i}}$, valor da probabilidade de ocorrência de sobras, e $1-P_{i}$, valor de probabilidade de não ocorrência de sobras (prejuízo) nas cooperativas.

No presente estudo, serão adotados dois modelos distintos, sendo que o modelo 1 servirá de base para o segundo, quando, este referente apenas aos anos de 1990 a 2000 (modelo 2). Essas alterações foram feitas no sentido de verificar as alterações ocorridas em relação ao modelo 1 .

Esses modelos terão como variável dependente a ocorrência de sobras nas cooperativas agropecuárias durante o período considerado em análise, representado por uma variável dicotômica que assume o valor $Y=1$ se a cooperativa obteve sobras e $Y=0$ se a cooperativa obteve prejuízo.

As variáveis independentes utilizadas nos modelos 1 e 2 foram:

a) CCMG - Valor dos Contratos de Crédito para Custeio do Café em Minas Gerais

b) TXCAM - Taxa de Câmbio em reais

c) PRSCUS - Preço médio da Saca de Café beneficiado $(60 \mathrm{~kg})$ pago ao produtor pela cooperativa

d) LC - Índice de Liquidez Corrente

e) ELP - Índice de Endividamento de Longo Prazo 


\subsubsection{Resultados dos modelos analíticos}

A inclusão do modelo Logit neste estudo visa não apenas identificar, mas quantificar o impacto das variáveis na ocorrência de sobras nas cooperativas agropecuárias em análise, o que é realizado pela análise do efeito marginal.

Os resultados referente aos modelos discutidos anteriormente são apresentados na seqüência, acompanhados por uma breve discussão.

Tabela 14. Coeficientes estimados do modelo Logit para a ocorrência de sobras nas cooperativas de café em Minas Gerais, 1980 a 2000. (Modelo 01)

\begin{tabular}{llllcc}
\hline Variável & \multicolumn{1}{c}{ B } & S.E. & Sig & R & E.M. \\
\hline CCMG & $7,02 \mathrm{E}-09$ & $3,000 \mathrm{E}-09$ & 0,0193 & 0,1763 & 0,000072 \\
TXCAM & 1,7035 & 0,5928 & 0,0041 & 0,2366 & 0,267 \\
PRSCUS & $-0,0163$ & 0,0076 & 0,0320 & $-0,1524$ & $-0,000046$ \\
LC & 3,0322 & 1,0228 & 0,0030 & 0,2464 & 0,349 \\
ELP & 0,0235 & 0,0217 & 0,2788 & 0,00001 & 0,000505 \\
Constante & $-4,5097$ & 1,7391 & 0,2411 & - & - \\
\hline
\end{tabular}

Nota: Número de observaçōes: 116. Graus de liberdade: 111

Número de casos corretos: 108 E.M. = Efeito Marginal

$\mathrm{O}$ índice de acertos (ou número de casos corretos em relação ao total das observações) ficou em 87,04\%. O modelo ajustado identificou quatro variáveis estatisticamente significativas, quais sejam: valor dos Contratos do Crédito para Custeio do Café em Minas Gerais (CCMG), Taxa de Câmbio (TXCAM), Preço pago ao produtor da saca de café em dólar (PRSCUS) e Liquidez Corrente (LC), sendo que os coeficientes de CCMG e PRSCUS apresentaram significativos a menos de $5 \%$ e os coeficientes de TXCAM e LC apresentaram-se significativas a menos de 1\%. Essas variáveis também 
apresentaram resultados compatíveis com o esperado, sendo os sinais coerentes e os coeficientes estatisticamente diferentes de zero.

No modelo Logit, os coeficientes das variáveis explicativas não refletem o efeito marginal destas sobre a probabilidade de ocorrência de sobras nas cooperativas. $\mathrm{O}$ efeito marginal de cada variável explicativa sobre a probalidade não é constante, visto que depende do efeito do valor em que cada variável é considerada, ou seja, do valor médio de cada variável xi. (formula 16). Para determinar o efeito marginal de cada variável sobre a probabilidade de ocorrência de sobra nas cooperativas foram usados valores médios das variáveis explicativas LC, ELP e PRSCUS das cooperativas em estudo. Para as variáveis CCMG e TXCAM, são dados comuns a todas as cooperativas, portanto, dispensando o cálculo da média.

Neste estudo, apenas a variável endividamento de longo prazo (ELP) não foi estatisticamente significativa, apesar disso apresentou sinal coerente com o esperado.

Menegário (2001), ao avaliar a influência dos indicadores socioeconômicos na previsão de inadimplência no sistema financeiro das cooperativas agropecuárias do estado do Paraná, mostrou, através do Logit, que para o ano de 1996, o endividamento interno não teve influência significativa na situação de inadimplência das cooperativas agropecuárias paranaenses.

O coeficiente da variável valor dos Contratos do Crédito para o Custeio do Café em Minas Gerais (CCMG) foi estatisticamente significativo e o terceiro mais importante na explicação da ocorrência de sobras nas cooperativas.

O coeficiente positivo do CCMG mostra que seu efeito ocorre no mesmo sentido das sobras. Isto é, quando a quantidade de recursos diminuiu há um impacto negativo sobre as sobras.

Uma política creditícia com recursos abundantes, ainda que com taxas de juros reais, é importante para o bom desempenho das cooperativas. Deve-se considerar 
que a politica de crédito aqui analisada influenciou indiretamente as cooperativas, pois esses recursos foram direcionados também para os produtores de café. Portanto, linhas de crédito direto para as próprias cooperativas podem ter impactos ainda maiores na atividade cooperativista.

O coeficiente da variável Taxa de Câmbio (TXCAM) também foi estatisticamente significativo e o segundo mais importante na explicação da ocorrência de sobras nas cooperativas.

O coeficiente positivo da variável (TXCAM) mostra que seu efeito ocorre no mesmo sentido das sobras. Quando a variável (TXCAM) estava crescendo, ou seja, quando a taxa de câmbio estava se desvalorizando, houve um impacto positivo sobre as sobras. Uma variação de 1 ponto percentual na taxa de câmbio implica uma variação, no mesmo sentido, de 0,267 pontos percentuais nas sobras. Isso pode ser explicado pelo fato de que a venda de uma saca de café com o câmbio desvalorizado significa maior quantidade de reais recebidos pela cooperativa e também pelo produtor, pois a saca de café é uma commodity internacional com preço estabelecido em dólar.

Logato (1994), em seus estudos sobre os efeitos das políticas econômicas sobre a cafeicultura mineira de 1970 a 1990, confirma os resultados encontrados neste trabalho, no diz respeito ao poder de impacto dessa variável, ao afirmar que as altas taxações impostas à cafeicultura mineira via política cambial e comercial entre outras trouxeram sérios prejuízos, como desestímulo à atividade, perdas irreversíveis para o parque cafeeiro e a insolvência da produtor rural.

O preço pago ao produtor da saca de café em dólar (PRSCUS) foi estatisticamente significativo na explicação da ocorrência de sobras nas cooperativas e o coeficiente negativo mostra que seu efeito ocorre em sentido contrário ao das sobras. Quando a variável PRSCUS estava crescendo, ou seja, quando a cooperativa paga mais pela saca de café ao associado, as sobras decrescem. Como um dos objetivos sociais da cooperativa é a regulação de preços, então, ao se vender insumos mais baratos e comprar 
a produção de uma forma mais favorável ao produtor, espera-se que a empresa cooperativada não apresente resultados tão significativos.

Ou seja, quando o preço do café está crescendo, pela lei da demanda, significa que a oferta desse produto tende a crescer, mas o cooperado não é obrigado a entregar o café na cooperativa. Pela presença de empresas concorrentes não cooperativadas, intermediárias no mercado, a cooperativa, para assegurar a entrega do produto na empresa, acaba pagando um preço melhor para o cooperado, diminuindo com isso a sua margem.

Um cenário crescente de preços pagos aos produtores poderia implicar em maiores desembolsos, maiores custos de comercialização para as cooperativas influenciando negativamente as sobras. Aliado a esse fato e supondo que parte da comercialização possa acontecer sem a venda antecipada ou casada para a exportação, os aumentos de preços do café podem significar margens negativas de comercialização para as cooperativas e, assim, comprometer as sobras. No mercado de exportação de café, o descasamento das operações de compra e venda podem significar assunção de elevados riscos para a empresa ou cooperativa.

Por outro lado, conforme Bialoskorski Neto (1994), o desempenho econômico-financeiro da cooperativa estaria relacionado com problemas de estrutura de capital e com problemas de princípios doutrinários nos quais se assentam o cooperativismo. Conforme o autor, a questão doutrinária do cooperativismo quanto à inexistência de lucro tem levado esse setor a uma tendência de maximização do ganho isolado do produtor e não de sua cooperativa. Também devido ao fato de não ser definida a divisão entre a propriedade e o controle, acaba ocorrendo situações em que o ganho individual torna-se evidenciado em detrimento do coletivo. Quanto à estrutura de capital da cooperativa, o fato é que tais organizações, por apresentarem fortes limitações ao aporte de capital próprio, tem a tendência de apresentar uma estrutura de capital baseada em recursos de terceiros. Essa característica não seria propriamente um aspecto negativo se os custos financeiros das cooperativas não fossem tão elevados. $O$ autor 
também discorre acerca das cotas- partes. Elas são instrumentos financeiros nãoalienáveis e inegociáveis em mercados, portanto diferentes das ações de empresas de capital aberto. Por outro lado, a cooperativa não pode lançar título de dívidas, como as debêntures, para alavancar recursos no mercado, não podendo abrir seu capital de modo direto em mercados financeiros.

A variável Liquidez Corrente (LC) foi estatisticamente significativa na explicação da ocorrência de sobras nas cooperativas e a mais importante, uma vez que possui o maior efeito marginal, o que indica que uma variação de uma unidade na liquidez corrente causa uma variação, no mesmo sentido, de 0,35 na probabilidade de ocorrência de sobras, apresentando sinal coerente ao esperado.

Esse resultado mostra como os fatores de natureza administrativa específicos de cada cooperativa têm um peso considerável na ocorrência de sobras, uma vez que o indicador econômico-financeiro LC foi o mais significativo para a ocorrência de sobras.

Neste estudo a variável Endividamento de Longo Prazo (ELP) não foi estatisticamente significativa.

No âmbito de cooperativas, a estrutura de capital é um aspecto cujo aprofundamento está ainda para ser feito por meio de modelos teóricos e estudos empíricos. O fato concreto é que tais organizações, por apresentarem fortes limitações ao aporte de capital próprio, têm uma tendência a apresentar uma estrutura de capital baseada em recursos de terceiros.

Pode-se dizer que, devido ao fato da variável ELP não ter apresentado estatisticamente uma importância na ocorrência de sobras, o insucesso passado de muitas cooperativas acabou sinalizando ao sistema financeiro que se trata de um cliente de alto risco de crédito, podendo aumentar o custo do empréstimo e/ou o nível de garantia e, no limite, restringir o fornecimento de recursos. Além disso, as cooperativas não têm - tal como sociedades anônimas ou limitadas - uma legislação consolidada para 
casos de falência, que possa permitir ao credor acionar procedimentos legais para obter de volta seus recursos.

Fully et al. (2001), ao verificar a influência das variáveis econômicofinanceiras na ocorrência de sobras das seis maiores cooperativas de cafeicultores do estado de Minas de 1994 a 1999, constataram, através do modelo Logit, que as variáveis rentabilidade sobre vendas, giro dos ativos e rentabilidade dos investimentos ativos foram significativas a $5 \%$ de probabilidade; o endividamento total foi significativo a $10 \%$ de probabilidade e as variáveis margem de garantia e rentabilidade do patrimônio líquido não foram significativas.

A tabela 15 apresenta os resultados do modelo 2, onde foram consideradas as mesmas variáveis do modelo 1, mas referentes ao período de 1990 a 2000 . No que se refere ao grau de acerto para a ocorrência de sobras, pode-se dizer que houve uma redução de qualidade do modelo em relação ao modelo 1 pois o índice de acerto passou de $87,04 \%$ para $80,65 \%$.

Tabela 15. Coeficientes estimados do modelo logit para a ocorrência de sobras nas cooperativas de café em Minas Gerais, 1990-2000. (Modelo 02)

\begin{tabular}{lcccc}
\hline Variável & \multicolumn{1}{c}{ B } & S.E. & Sig & R \\
\hline CCMG & $7,66 \mathrm{E}-09$ & $4,072 \mathrm{E}-9$ & 0,0601 & 0,1391 \\
TXCAM & 1,0945 & 0,7195 & 0,1282 & 0,0629 \\
PRSCUS & $-0,0125$ & 0,0092 & 0,1760 & 0,00001 \\
LC & 2,5728 & 1,0115 & 0,0110 & 0,2373 \\
ELP & 0,0263 & 0,0228 & 0,2495 & 0,00001 \\
Constante & $-3,9223$ & 1,8241 & 0,0315 & -
\end{tabular}

Nota: Número de observações: 116. Graus de liberdade: 111 Número de casos corretos: 108 
O resultado encontrado na estimação do modelo 2 mostra que o coeficiente das variáveis TXCAM e PRSCUS, ao contrário do Modelo 1, não foram estatisticamente significativas, isto é, não demonstraram influência na ocorrência de sobras nas cooperativas em análise durante o período de 1990 a 2000. As outras variáveis mantiveram as mesmas tendências.

Se por um lado, a ocorrência de apreciação da taxa de câmbio nos anos de 1995 a 1998 e depois em 2000 (apêndice 2), auxiliou o processo de estabilização de preços, por outro prejudicou os setores direta ou indiretamente ligados aos produtos de exportação. Uma valorização do câmbio significa menor quantidade de reais recebidos pela cooperativa e, como importadora de insumos, implica uma diminuição de custos. Esses dois efeitos nos preços agrícolas de maneira diferenciada poderia ter anulado o impacto da valorização do câmbio sobre o resultado liquido do setor cooperativista agrícola durante a década de 90 . 


\section{CONCLUSÕES}

Após décadas de vigência de um modelo de política agrícola baseada em crédito rural subsidiado, sobreveio um período de grande abertura comercial e menor participação do estado, levando cooperativas e demais empresas do pais a atuarem num contexto econômico financeiro submetido a transformações rápidas e profundas. Essas transformações promoveram considerável impacto sobre a agricultura agravando-se ainda mais, mediante o alto grau de protecionismo dos países desenvolvidos aos seus produtores.

As políticas econômicas, de modo geral, e aquelas direcionadas influenciaram, de forma diferenciada, os diversos setores da economia. O presente trabalho teve como objetivo geral analisar o impacto das variáveis macroeconômicas para a agricultura no desempenho das cooperativas de café do estado de Minas Gerais, durante o período de 1980 a 2000. Especificamente, buscou-se analisar o comportamento dos indicadores financeiros das cooperativas estudados ao longo da série de anos.

De acordo com os resultados obtidos através dos modelos ajustados, durante o período de 1980 a 2000, o crédito rural, a taxa de câmbio e o preço do café foram importantes na explicação de ocorrência de sobras nas maiores cooperativas de cafeicultores do estado de Minas. Entretanto, ao considerar apenas o período de 1990 a 
2000, a taxa de câmbio e o preço do café não foram significativos na explicação das sobras; e o crédito rural passou a ser menos significativo.

A conjugação de variáveis macroeconômicas e financeiras no modelo estimado mostram, de certa forma, como os fatores de gestão financeira específicos de cada cooperativa têm um peso considerável na ocorrência de sobras, uma vez que o indicador Liquidez Corrente foi significativo para a ocorrência de sobras.

Os indicadores econômico-financeiros médios das cooperativas em estudo:Endividamento Total, Rentabilidade do Patrimônio Líquido, Independência Financeira e Rentabilidade sobre Investimento - apresentaram, durante a década de 80, apesar da crise fiscal e financeira do Estado e dos altos índices de inflação, os melhores patamares, quando comparados com os anos 90 que antecederam o período de estabilização da economia. Uma nova recuperação ocorreu somente após 1994.

O Endividamento de Longo Prazo e a Margem de Garantia também apresentaram melhores médias na década de 80 , em comparação com os anos 90, mas decresceram durante o período de estabilização.

Já os valores médios da Liquidez Corrente, Liquidez Seca, Giro do Ativo e Imobilização dos Recursos próprios apresentaram os melhores patamares na década de 90 em relação à década de 80 , vindo subir as médias a partir de 1994, com exceção do Giro do Ativo e Imobilização dos Recursos próprios, que decresceram no período de estabilidade da inflação.

Os resultados aqui encontrados mostraram que o desempenho econômicofinanceiro das cooperativas não está apenas relacionado com problemas de estrutura de capital e de princípios doutrinários nos quais se assentam o cooperativismo, mas também com o comportamento das variáveis macroeconômicas da economia onde estão inseridas. 
Visto que a taxa de câmbio, o crédito agrícola e preço do café foram importantes na explicação de ocorrência de sobras nas cooperativas de cafeicultores do estado de Minas, torna-se necessária a definição de novas posturas e conduta da ação governamental no redirecionamento das políticas no sentido de permitir que essas organizações possam fazer frente à concorrência em um mercado globalizado.

Espera-se, porém, que este trabalho sirva como referência, para que outras pesquisas venham a ser realizadas. Sugere-se que novos estudos com cooperativas agropecuárias de outras especializações como leite ou grãos, sejam efetuados de modo a contribuir para a corroboração de que variáveis macroeconômicas são de fundamental importância para explicar o desempenho das cooperativas agropecuárias, ampliando-se mais o campo de análise e discussão. 


\section{REFERÊNCIAS BIBLIOGRÁFICAS}

ARAÚJO, P.F.C.; MEYER, R.L. Políticas de crédito agrícola no Brasil: objetivos e resultados. In: Ensaios sobre política agrícola brasileira. São Paulo: Secretaria da Agricultura, 1979. p.137-162.

ASSAF NETO, A. Estrutura e análise de balanços: um enfoque econômico-financeiro. São Paulo: Atlas, 1998. 292p.

BANCO CENTRAL DO BRASIL. Anuário estatístico do crédito rural. Brasília, 1980-2000.

BARROS, G.S.C. A transição na política agrícola brasileira. In: CONGRESSO BRASILEIRO DE ECONOMIA E SOCIOLOGIA RURAL, 36., Poços de Caldas, 1998. Anais. Brasília: SOBER, 1998. v.1, p.1-20.

BENECKE, D.W. Cooperação e desenvolvimento: o papel das cooperativas no processo de desenvolvimento econômico nos países do terceiro mundo. Porto Alegre: COOJORNAL; Recife: ASSOCENE, 1980. 240p.

BIALOSKORSKI NETO, S. (Org.). Política institucional de monitoramento da autogestão das cooperativas do Estado de São Paulo: uma proposta preliminar de metodologia, pesquisa e implantação: resultados da primeira fase. Ribeirão Preto: USP, FEA, 2000. 127p. 
BIALOSKORSKI NETO, S. A empresa cooperativa e o ambiente institucional após o XI Congresso Brasileiro de Cooperativismo. Gestão Cooperativa, v.2, n.3, p.46, abr. 1998.

BIALOSKORSKI NETO, S. Agribusiness cooperativo: economia, doutrina e estratégias de gestão. Piracicaba, 1994. 135p. Dissertação (Mestrado) - Escola Superior de Agricultura "Luiz de Queiroz”, Universidade de São Paulo.

BIALOSKORSKI NETO, S. Cooperativas: economia, crescimento e estrutura de capital. Piracicaba, 1998. 257p. Tese (Doutorado) - Escola Superior de Agricultura "Luiz de Queiroz”, Universidade de São Paulo.

BIALOSKORSKI NETO, S. Cooperativismo: direitos de propriedade e eficiência econômica, a nova geração de cooperativas no Canadá. In: CONGRESSO BRASILEIRO DE ECONOMIA E SOCIOLOGIA RURAL, 36., Poços de Caldas, 1998. Anais. Brasília: SOBER, 1998. v.2, p.745-754.

BIANCO, J. A dinâmica do financiamento da agropecuária: crédito rural e agroindustrialização nas regiões de Marília e do Vale do Paranapanema - SP. Campinas, 1995. 99p. Dissertação (Mestrado) - Universidade Estadual de Campinas.

BIANCO, J.; CARDOSO, J.L.; FUCHIDA, M.A.; FREITAS, M.L. Revitalização do segmento cooperativista agropecuário - RECOOP. In: CONGRESSO BRASILEIRO DE ECONOMIA E SOCIOlOGIA RURAL, 36., Poços de Caldas, 1998. Anais. Brasília: SOBER, 1998. v.2, p.793-802.

BLUMENSCHEIN, F.N. Uma análise da proteção efetiva na agricultura do Estado de São Paulo. Piracicaba, 1982. 149p. Dissertação (Mestrado) - Escola Superior de Agricultura "Luiz de Queiroz”, Universidade de São Paulo.

BRANDÃO, A.S.P.; ALVES, E. Elementos de uma estratégia para o desenvolvimento da agricultura brasileira. Ensaios Econômicos da EPGE, n.209, p.1-30, fev. 1993. 
CAIXETA, G.Z.T. A cafeicultura de Minas Gerais. Viçosa: EPAMIG, 1985. 107p.

CAIXETA, G.Z.T. Importância da cafeicultura para o Brasil e para Minas Gerais: mercado cafeeiro mundial e a Organização Internacional do Café, ciclos de produção e preços, políticas de preço e comportamento do mercado cafeeiro. $5^{\text {a }}$ ed. Viçosa: UFV, 1987.32p.

CAIXETA, G.Z.T. Tendência do mercado de café do Brasil. Revista de Economia Rural, v.27, n.2, p.173-96, 1989.

CAMARGO, J.M.; NERR, M.; REIS, M.C. Emprego e produtividade no Brasil na década de 1990. In: BAUMANN, R. (Org.). Brasil: uma década em transição. Rio de Janeiro: Campus, 1999. p.256-287.

CAMPELO JÚNIOR, A. O ranking das 100 maiores do agronegócio. Agroanalysis, v. 20, n. 10 , p.14-34, out. 2000 .

CAMPOS, A.C. Avaliação da intervenção do Estado em cadeias agro-industriais. In: Agricultura na virada do milênio: velhos e novos desafios. Viçosa: UFV, 2000. $458 \mathrm{p}$.

CARDOSO, J.L. Política de crédito rural no Brasil: uma análise dos dados estatísticos de 1983 a 1985. In: ENCONTRO DOS GRUPOS TEMÁTICOS DO PROJETO DE INTERCÂMBIO DE PESQUISA SOCIAL EM AGRICULTURA, 13., Rio de Janeiro, 1988. Anais. Botucatu: UNESP, FCA, DER, 1989. p.773-801

CARDOSO, J.L. Política de crédito rural: retrospectiva e tendências de um novo padrão de financiamento. In: CONGRESSO BRASILEIRO DE ECONOMIA E SOCIOLOGIA RURAL, 35., Natal, 1997. Anais. Brasília: SOBER, 1997. p.186-197.

CARVALHO, F.M.A. Crédito rural no Brasil: evolução, resultados e perspectivas. In: Agricultura na virada do milênio: velhos e novos desafios. Viçosa: UFV, 2000. p.77-92. 
CHABARIBERLY, D.; MELLO, N.T.C. Aspectos da política de crédito de custeio agrícola no Estado de São Paulo: valores, liberações e encargos financeiros, 1979 a 1987. São Paulo: Secretaria de Agricultura e Abastecimento, 1988. 31p. (IEA, Relatório de Pesquisa, 6)

COFFEE BUSINESS. Anuário estatístico do café. 6.ed. Rio de Janeiro, 2000/2001.

CONTINI, E.; GONTIJO, V. Política agrícola brasileira numa economia aberta. Viçosa: E.C. Teixeira, 1993. p.131-142.

DE JANVRY, A.; KEY, N.; SAUDOLET, E. Agricultural and rural development in Latin America: new directions and new challenges. Berkeley: University of Califórnia, Department of Agricultural and Resource Economics, 1997. 43p. (Working Paper, 815)

DIAS, G.L.S.; AMARAL, C.M. Mudanças estruturais na agricultura brasileira, 19801998. In: BAUMANN, R. (Org.). Brasil: uma década em transição. Rio de Janeiro: Campus, 1999. p.224-253.

DORNELAS, S. Dois pesos e uma medida. Agroanalysis, v.20, n.12, p.28-29, dez. 1998.

DUQUE, M.C.; AZEVEDO FILHO, A.J.B.V. Crédito e inadimplência nos setores agrários e não-agrários. In: CONGRESSO BRASILEIRO DE ECONOMIA E SOCIOLOGIA RURAL, 35., Natal, 1997. Anais. Brasília: SOBER, 1997. p.394.

FAGUNDES, M.H. Comentários sobre crédito rural e sua evolução recente. Brasília: Companhia de Financiamento da Produção, 1987. 180p. (Coleção de Estudos Especiais, 21)

FERREIRA, R.N. Índices padrão e situação econômica financeira e político-social de cooperativas de leite e café da região Sul do Estado de Minas Gerais. Lavras, 1999. 138p. Dissertação (Mestrado) - Universidade Federal de Lavras. 
FRANCO, J.M.C. Transferência de renda da agricultura comercial e familiar no Brasil. Viçosa, 1998. 145p. Dissertação (Mestrado) - Universidade Federal de Viçosa.

FULLY, V.G.; LIMA, J.E.; BRAGA, M.J. Avaliação de estratégias financeiras das cooperativas de cafeicultores do estado de Minas Gerais. In: CONGRESSO BRASILEIRO DE ECONOMIA E SOCIOLOGIA RURAL, 39., Recife, 2001. Anais. Brasília: SOBER, 2001. p.1-11.

GASQUES, J.G. Gastos públicos na agricultura. In: GASQUES, J.G.; CONCEIÇÃO, J.C.P.R. da; FERREIRA, B. (Org.). Transformações da agricultura e políticas públicas. Brasília: IPEA, 2001. p.157-190.

GASQUES, J.G.; CONCEIÇÃO, J.C.P.R. Transformações estruturais da agricultura e produtividade total dos fatores. In: GASQUES, J.G.; CONCEIÇÃO, J.C.P.R. da; FERREIRA, B. (Org.). Transformações da agricultura e políticas públicas. Brasília: IPEA, 2001. p.17-92.

GASQUES, J.G.; VILLA VERDE, C.M. Crescimento da agricultura brasileira e política agrícola nos anos 80. In: CONGRESSO BRASILEIRO DE ECONOMIA E SOCIOLOGIA RURAL, 28., Florianópolis, 1990. Anais. Brasília: SOBER, 1990. v.1, p.185-214.

GIMENES, R.M.T. Análisis del comportamiento de los administradores financieros respecto al coste y estructura de capital. aplicación a las cooperativas agropecuárias de estado del Paraná. León, 1999. 333p. Tese (Doctoral) - Universidade de Leon.

GIMENES, R.M.T.; OPASO, M.A. Modelos multivariantes para a previsão de insolvência entre a análise discriminante e a análise de probabilidade condicional: logit. Caderno de Pesquisas em Administração, v.8, n.3, p.65-75, jul./set. 2001.

GOLDIN, 1.; REZENDE, G.C. A agricultura brasileira na década de 80: crescimento numa economia em crise. Brasília: IPEA, 1993. 119p. 
GOMES, A.P.; FINAMORE, E.B. Algumas questões macroeconômicas e a agricultura brasileira. In: Agricultura na virada do milênio: velhos e novos desafios. Viçosa: UFV, 2000. p.341-368.

GRAZIANO, J.S. A nova dinâmica da agricultura brasileira. Campinas: UNICAMP, Instituto de Economia, 1996. 217p.

GREMAUD, A.P.; VASCONCELLOS, M.A.S. de ; JONETO JUNIOR, R. Economia brasileira contemporânea. 4.ed. São Paulo: Atlas, 2002.626p.

HELFAND, S.M.; RESENDE, G.C. A agricultura brasileira nos anos 90: o impacto das reformas de políticas. In: GASQUES, J.G.; CONCEIÇÃO, J.C.P.R. da; FERREIRA, B. (Org.). Transformações da agricultura e políticas públicas. Brasília: IPEA, 2001. p.247-301.

LEITE, C.A.M. Política agrícola para o setor rural em transição In: Agricultura na virada do milênio: velhos e novos desafios. Viçosa: UFV, 2000. p.193-216.

LOGATO, E.S. Efeitos das políticas econômicas sobre a cafeicultura mineira 1970/1990. Viçosa, 1994. 137p. Dissertação (Mestrado) - Universidade Federal de Viçosa.

LOPES, M. de R. O poder das coalizões políticas de grupos de interesse de bloquear o desenvolvimento agrícola. In: TEIXEIRA, E.C. (Ed.). Desenvolvimento agrícola na década de 90 e no século XXI. Viçosa: UFV, 1993. p.105-30.

LOPES, M. de R. A intervenção do governo nos mercados agrícolas no Brasil: o sistema de regras de interferência no mecanismo de preços. Brasília: CIP, 1986. 108p. (Coleção Análise e Pesquisa, 37)

LOPES, M. de R. O câmbio real, o setor exportador e a agricultura. Conjuntura Econômica, v.48, n.8, p.184-187, ago. 1994. 
SAES, M.M.S. Discutindo cenários para o sistema agro-industrial do café no Brasil. São Paulo: PENSA/FIPE/FEA, 1999. /Apresentado à Jornada Café com Leite. Documentos Base para Discussão, São Paulo, 1999/

MATARAZZO, D.C. Análise financeira de balanços: abordagem básica e gerencial. São Paulo: Atlas, 1998. 463p.

MENEGÁRIO, A.H. Emprego de indicadores sócio-econômicos na avaliação financeira de cooperativas agropecuárias. Piracicaba, 2000. 121p. Tese (Mestrado) - Escola Superior de Agricultura "Luiz de Queiroz", Universidade de São Paulo.

MENEGÁRIO, A.H.; ARAÚJO, P.F.C. de. Indicadores sócio-econômicos na avaliação financeira de cooperativas agropecuárias. Economia Aplicada v.5, n.4, p.757-785, out./dez. 2001.

MEYER, L.F.F.; BRAGA, M.J. Resultados e contradições da política de modernização da agricultura brasileira. In: Agricultura na virada do milênio: velhos e novos desafios. Viçosa: UFV, 2000. p.51-76.

MÜLER, G. A economia política do complexo agro-industrial. In: CONGRESSO BRASILEIRO DE ECONOMIA E SOCIOLOGIA RURAL, 24., Lavras, 1986. Anais. Brasília: SOBER, 1986. v.1, p.347-367.

MUNHOZ, D.G. Economia agrícola: agricultura, uma defesa dos subsídios. Petrópolis: Vozes, 1982. $107 \mathrm{p}$.

NEGRI NETO, A.; COELHO, P.J.; MOREIRA, I.R.O. Análise gráfica e taxa de crescimento. Informações Econômicas, v.23, n.10, p.99-108, 1993.

NOGUEIRA, J.M; OLIVEIRA, D.H. As origens do endividamento da agricultura brasileira: considerações sobre os impactos das políticas macroeconômicas nas politicas setoriais. In: CONGRESSO BRASILEIRO DE ECONOMIA E SOCIOLOGIA RURAL, 35., Natal, 1997. Anais. Brasília: SOBER, 1997. p.295-296. 
OLIVEIRA JÚNIOR, C.C. de. Avaliação da eficiência empresarial das cooperativas. 3.ed. Curitiba: OCEPAR, 1996. 79p. (Série cooperativismo, 14)

ORGANIZAÇÃO DAS COOPERATIVAS BRASILEIRAS. Números do cooperativismo brasileiro. Brasília: OCB, Depto. Técnico e Econômico, 1997. 20p.

ORGANIZAÇÃO DAS COOPERATIVAS BRASILEIRAS. Números do cooperativismo brasileiro. Brasília: OCB, Depto. Técnico e Econômico, 2000. 20p.

ORGANIZAÇÃO DAS COOPERATIVAS BRASILEIRAS. O cooperativismo no Brasil. Brasília: OCB, Depto. Técnico e Econômico, 1999. 52p.

PADOVEZE, C.L. Contabilidade gerencial: um enfoque em sistema de informações contábil. São Paulo: Atlas, 1996. 392p.

PANZUTTI, R. Especificidades da empresa cooperativa agrícola: estratégia de financiamento. Agricultura em São Paulo, v.44, n.1, p.75-118, 1997.

PEREIRA, A.C. Contabilização e estruturação das demonstrações contábeis das sociedades cooperativas brasileiras: um enfoque social. Revista Brasileira de Contabilidade, v.26, n.106, p.12-20, jul./ago.1997.

PEREIRA, A.C. Contribuição à análise e estruturação das demonstrações financeiras das sociedades cooperativas brasileiras: ensaio de abordagem social. São Paulo, 1993. 325p. Tese (Doutorado) - Faculdade de Economia, Administração e Contabilidade, Universidade de São Paulo.

PEREIRA, M.P. Paridade de juros, fluxo de capitais e eficiência do mercado de câmbio no Brasil: evidência dos anos 90. São Paulo, 1999. 153p. Dissertação (Mestrado) Faculdade de Economia, Administração e Contabilidade, Universidade de São Paulo.

PÉREZ, A.M.A.B. Problemas de agencia y de elección contable derivados de la regulación de las cooperativas agrarias. Oviedo, 1999. Tese (Doctoral) - Universidade de Oviedo. 
PINHEIRO, A.C.; BORGES, C.P.; ZANGURY, S.; MESQUITA, M. Uma avaliação setorial da política de incentivo às exportações no Brasil. In: INSTITUTO DE PESQUISA ECONÔMICA APLICADA. Perspectivas da economia brasileira. Rio de Janeiro, 1994. v.1, p.339-358.

PINHEIRO, A.C.; GIAMBIAGI, F.; GOSTKORZEWICZ, J. O desempenho macroeconômico do Brasil nos anos 90. In: GIAMBIAGI, F.; MOREIRA, M.M. (Org.). A economia brasileira nos anos 90. Rio de Janeiro: BNDES, 1999. p.13-41.

PIRES, M.M.; H.; KAN-CHINGS, M.H.F.L.; TEIXEIRA, E.C.; FILHO, J.I.S. Efeitos de políticas governamentais na cultura do milho - Brasil, 1970 a 1990. In: CONGRESSO BRASILEIRO DE ECONOMIA E SOCIOLOGIA RURAL, 33., Curitiba, 1995. Anais. Brasília: SOBER, 1995. v.2, p.350-374.

PONCIANO, N.J.; REZENDE, A.M.; CAMPOS, A.C. Comportamento das margens de comercialização do café brasileiro destinado à exportação. In: CONGRESSO BRASILEIRO DE ECONOMIA E SOCIOLOGIA RURAL, 33., Curitiba, 1995. Anais. Brasília: SOBER, 1995. v.2, p.993-1006.

REQUEJO, L.M.H. Lack of monitoring of agricultural cooperatives in Brazil: evidence and prospects for improvement. http://www.agrosoft.com.br/eventos/agrosoft 97/trabalho.htm (08 ago. 1999)

REZENDE, A.M.; GOMES, M.F.M.; PONCIANO, N.J. et al. A inserção brasileira no mercado internacional de commodities. In: LÍRIO, V.S.; GOMES, M.F.M. Investimento privado, público e mercado de commodities. Viçosa: UFV, DER, 2000. p.1-48.

REZENDE, G.C. Política de crédito rural e expansão agrícola dos Cerrados. In: GASQUES, J.G.; CONCEIÇÃO, J.C.P.R. da; FERREIRA， B. (Org.). Transformações da agricultura e políticas públicas. Brasília: IPEA, 2001. p.213246. 
REZENDE, G.C.; NONNEMBERG, M.J.; MARQUES, M.C. Abertura comercial, financiamento das importações e o impacto sobre o setor agrícola. In: CONGRESSO BRASILEIRO DE ECONOMIA E SOCIOLOGIA RURAL, 35., Natal, 1997. Anais. Brasília: SOBER, 1997. p.298.

ROCHA, L.E.V.; TEIXEIRA, C.T. Taxa de câmbio real, políticas macroeconômicas e comportamento dos preços agrícolas - 1961 a 1987. In: CONGRESSO BRASILEIRO DE ECONOMIA E SOCIOLOGIA RURAL, 35., Natal, 1997. Anais. Brasília: SOBER, 1997. p.285-286.

RODRIGUES, R. O cooperativismo na globalização. Agroanalysis, v.17, n.8, p.10-12, ago. 1997.

RODRIGUES, R.L. Cooperativas agropecuárias e relações intersetoriais na economia paranaense: uma análise de insumo-produto. Piracicaba, 2000. 171p. Tese (Doutorado) - Escola Superior de Agricultura "Luiz de Queiroz”, Universidade de São Paulo.

SCHUH, G.E. Efeitos de políticas gerais de desenvolvimento agrícola. In: Desenvolvimento da agricultura: análise de política econômica. São Paulo: Pioneira, 1975. p.3-12.

SEXTON, R.J. Cooperatives and the forces shaping agricultural marketing. American Journal of Agricultural Economics, v.68, n.5, p.1167-1172, 1986.

SILVA, C.R.L. da; CARVALHO, M.A. de. Taxa de câmbio e preços de commodities agrícolas. Informações Econômicas, v.25, n.5, p.23-35, 1995.

TEIXEIRA, E.C. Política de garantia de renda. In: Agricultura na virada do milênio: velhos e novos desafios. Viçosa: Universidade Federal de Viçosa, 2000. p.217-236. 
TEIXEIRA, E.C.; AGUIAR, D.R.D.; VIEIRA, W. da C. In: Reforma da política agrícola e abertura econômica. Viçosa: E.C. Teixeira; W. da C. Vieira, 1996. p.1118.

VIEIRA, W. da C. Interdependência entre agricultura e mercado financeiro: um modelo teórico. In: CONGRESSO BRASILEIRO DE ECONOMIA E SOCIOLOGIA RURAL, 35., Natal, 1997. Anais. Brasília: SOBER, 1997. p.283-284.

VIEIRA, W. da C. Políticas macroeconômicas e agricultura sob regimes cambiais alternativos. In: Agricultura na virada do milênio: velhos e novos desafios. Viçosa: Universidade Federal de Viçosa, 2000. p.265-282.

ZINI JUNIOR, A.A. Taxa de câmbio e a política cambial no Brasil. 2.ed. São Paulo: EDUSP, 1995. p.1-10. 
APÊNDICES 
APÊNDICE 1 - Recebimento de crédito no Brasil, Valor dos contratos do crédito para o café no Brasil e valor dos contratos do crédito para o café em Minas Gerais (Em reais/dez. 2000), no período de 1980 a 2000 .

\begin{tabular}{|r|r|r|r|}
\hline Anos & \multicolumn{1}{|c|}{ RCBR } & \multicolumn{1}{c|}{ CCBR } & \multicolumn{1}{c|}{ CCMG } \\
\hline 1980 & $37.451 .763 .627,46$ & $3.202 .167 .180,66$ & $924.108 .038,45$ \\
\hline 1981 & $32.483 .312 .779,85$ & $1.675 .278 .023,27$ & $470.256 .175,55$ \\
\hline 1982 & $31.456 .037 .605,93$ & $2.176 .281 .896,34$ & $593.476 .847,85$ \\
\hline 1983 & $23.745 .870 .117,17$ & $1.392 .373 .476,50$ & $383.032 .876,00$ \\
\hline 1984 & $14.503 .901 .260,22$ & $747.956 .787,49$ & $254.642 .225,42$ \\
\hline 1985 & $20.682 .649 .790,62$ & $831.766 .077,34$ & $46.962 .019,95$ \\
\hline 1986 & $30.842 .602 .921,38$ & $871.885 .507,99$ & $289.072 .358,18$ \\
\hline 1987 & $24.312 .430 .789,90$ & $1.247 .523 .678,76$ & $493.022 .404,62$ \\
\hline 1988 & $17.156 .139 .639,14$ & $449.459 .309,35$ & $16300.010,22$ \\
\hline 1989 & $15.666 .987 .263,25$ & $605.347 .708,06$ & $290.791 .055,01$ \\
\hline 1990 & $8.950 .225 .761,63$ & $397.238 .985,70$ & $245.150 .770,90$ \\
\hline 1991 & $9.233 .093 .448,35$ & $269.195 .326,76$ & $136.841 .506,05$ \\
\hline 1992 & $10.237 .863 .520,98$ & $177.920 .317,36$ & $75.134 .513,64$ \\
\hline 1993 & $8.792 .434 .672,41$ & $60.918 .851,45$ & $18.856 .747,82$ \\
\hline 1994 & $12.715 .161 .578,80$ & $77.152 .949,86$ & $46.800 .691,40$ \\
\hline 1995 & $5.516 .891 .602,41$ & $148.750 .816,26$ & $63.746 .149,92$ \\
\hline 1996 & $4.821 .613 .569,42$ & $231.314 .844,18$ & $36.763 .922,74$ \\
\hline 1997 & $6.985 .987 .400,05$ & $455.827 .155,25$ & $304.964 .263,18$ \\
\hline 1998 & $7.608 .665 .431,03$ & $370.932 .090,17$ & $222.404 .538,62$ \\
\hline 1999 & $7.234 .320 .936,71$ & $373.994 .957,03$ & $114.421 .341,20$ \\
\hline 2000 & $7.048 .151 .313,89$ & $300.848 .496,90$ & $182.404 .372,31$ \\
\hline
\end{tabular}

RRBR - Recursos do crédito no Brasil

CCBR - Crédito para o café no Brasil

CCMG - Crédito para o café em Minas Gerais

Fonte: Manual do Crédito Rural - Banco Central (vários anos) 
APÊNDICE 2 - Preço médio da saca de café (em US\$), Participação de Minas Gerais na produção de café brasileira e taxa de câmbio em real.

\begin{tabular}{|r|r|r|r|}
\hline \multirow{2}{*}{ Anos } & \multicolumn{1}{|c|}{ PRSCUS\$ } & \multicolumn{1}{|c|}{$\begin{array}{l}\text { PARTIC } \\
\text { MG }^{\mathbf{2}}\end{array}$} & \multicolumn{1}{c|}{ Taxa de Câmbio $^{3}$} \\
\hline 1980 & 95,32 & $59,85 \%$ & 2,3015234 \\
\hline 1981 & 78,54 & $19,54 \%$ & 1,936114 \\
\hline 1982 & 87,78 & $34,12 \%$ & 1,9081747 \\
\hline 1983 & 65,50 & $24,69 \%$ & 2,4109979 \\
\hline 1984 & 72,75 & $31,58 \%$ & 2,4063214 \\
\hline 1985 & 115,75 & $25,23 \%$ & 2,475068 \\
\hline 1986 & 219,18 & $32,82 \%$ & 2,2523445 \\
\hline 1987 & 68,81 & $31,85 \%$ & 1,9990141 \\
\hline 1988 & 67,13 & $30,77 \%$ & 1,6996721 \\
\hline 1989 & 92,46 & $42,72 \%$ & 1,2924612 \\
\hline 1990 & 83,38 & $39,74 \%$ & 1,0957049 \\
\hline 1991 & 62,17 & $29,35 \%$ & 0,8582848 \\
\hline 1992 & 53,09 & $47,37 \%$ & 1,2583081 \\
\hline 1993 & 66,88 & $39,58 \%$ & 1,1492913 \\
\hline 1994 & 141,99 & $45,61 \%$ & 2,503236 \\
\hline 1995 & 145,90 & $50,00 \%$ & 0,7808564 \\
\hline 1996 & 123,67 & $54,76 \%$ & 0,7700698 \\
\hline 1997 & 184,28 & $54,55 \%$ & 0,765372 \\
\hline 1998 & 136,35 & $45,97 \%$ & 0,793134 \\
\hline 1999 & 99,75 & $50,93 \%$ & 1,1138586 \\
\hline 2000 & 87,64 & $51,16 \%$ & 0,9361387 \\
\hline
\end{tabular}

': Fonte: dados da pesquisa com base nos relatórios das sete cooperativas em análise. De vários anos.

${ }^{2}$ : Fonte: Anuário Estatístico do Café (2000).

${ }^{3}$ : Fonte: Revista Conjuntura Econômica de dezembro/2001 (Número 12), expressas em R\$/US\$ e foram corrigidas com base no IGP-DI de agosto/94. 
APÊNDICE 3 - Dados Financeiros Médios das Sete Cooperativas de Café De Minas Gerais, Valores em Reais (Dez. 2000).

\begin{tabular}{|c|c|c|c|c|c|c|c|c|c|c|}
\hline Anos & $\mathrm{GA}$ & RI & $\begin{array}{c}\text { ELP } \\
(\%)\end{array}$ & $\begin{array}{c}\text { ET } \\
(\%)\end{array}$ & $\begin{array}{c}\text { IF } \\
(\%)\end{array}$ & IRP & MG & $\overline{L S}$ & LC & RPL \\
\hline 1980 & 2,67 & 6,10 & 1,87 & 60,86 & 20,31 & 0,58 & 1,83 & 0,90 & 1,22 & 0,30 \\
\hline 1981 & 1,53 & 8,65 & 1,59 & 70,18 & 26,04 & 0,58 & 1,37 & 0,68 & 1,14 & 0,33 \\
\hline 1982 & 1,77 & 6,77 & 1,00 & 67,80 & 27,55 & 0,55 & 1,44 & 0,92 & 1,22 & 0,25 \\
\hline 1983 & 1,51 & 13,01 & 0,87 & 32,28 & 56,30 & 0,63 & 2,06 & 0,68 & 1,23 & 0,27 \\
\hline 1984 & 0,97 & 12,79 & 0,31 & 50,43 & 40,26 & 0,61 & 2,54 & 0,73 & 1,43 & 0,29 \\
\hline 1985 & 1,32 & 16,59 & 0,28 & 35,28 & 45,44 & 0,60 & 2,83 & 1,29 & 2,45 & 0,33 \\
\hline 1986 & 0,98 & 5,78 & 0,46 & 63,51 & 34,27 & 0,67 & 2,43 & 1,11 & 1,35 & $(0,02)$ \\
\hline 1987 & 0,83 & 7,60 & 0,52 & 58,34 & 40,61 & 0,70 & 2,10 & 0,72 & 1,12 & 0,17 \\
\hline 1988 & 0,75 & 6,37 & 7,16 & 45,01 & 36,57 & 0,76 & 1,80 & 0,95 & 1,25 & 0,15 \\
\hline 1989 & 0,45 & 5,93 & 3,78 & 47,89 & 42,81 & 0,86 & 1,98 & 0,73 & 1,15 & 0,17 \\
\hline 1990 & 0,80 & 6,75 & 2,65 & 60,82 & 33,87 & 0,89 & 1,78 & 0,76 & 1,14 & 0,17 \\
\hline 1991 & 2,05 & $-2,30$ & 0,69 & 63,88 & 39,93 & 1,04 & 1,97 & 0,76 & 1,03 & $-0,09$ \\
\hline 1992 & 1,39 & 8,23 & 14,47 & 25,28 & 39,56 & 0,96 & 2,11 & 0,87 & 1,27 & 0,28 \\
\hline 1993 & 1,43 & $11,97^{-}$ & 16,28 & 29,72 & 31,21 & 0,67 & 2,22 & 0,92 & 1,23 & 0,23 \\
\hline 1994 & 2,56 & $-2,10$ & 16,20 & 42,86 & 18,27 & 0,73 & 1,87 & 0,71 & 1,05 & 0,19 \\
\hline 1995 & 2,44 & 0,22 & 13,83 & 40,24 & 25,32 & 0,67 & 2,10 & 0,76 & 1,04 & 0,09 \\
\hline 1996 & 2,77 & 2,83 & 22,93 & 15,19 & 25,53 & 0,52 & 2,31 & 1,20 & 1,57 & 0,15 \\
\hline 1997 & 3,21 & 5,77 & 20,91 & 11,83 & 44,13 & 0,78 & 2,24 & 1,56 & 1,92 & 0,62 \\
\hline 1998 & 2,52 & 7,81 & 16,52 & 24,85 & 40,09 & 0,62 & 1,99 & 1,15 & 1,51 & 0,40 \\
\hline 1999 & 2,20 & 4,80 & 16,15 & 28,12 & 36,29 & 0,52 & 1,77 & 1,21 & 1,58 & 0,14 \\
\hline 2000 & 1,48 & 1,33 & 2,74 & 10,92 & 9,76 & 0,14 & 0,53 & 0,31 & 0,41 & 0,04 \\
\hline
\end{tabular}

Fonte: Dados da pesquisa 